PRU-8185

DE92 019094

\title{
ANALYSIS OF THE INDUSTRIAL SECTOR RFPRESENTATION IN THE FOSSIL2 ENERGY-ECONOMIC MODEL
}

\author{
M. A. Wise \\ M. G. Woodruff \\ W. B. Ashton
}

August 1992

Prepared for the U.S. Department of Energy under Contract DE-ACO6-76RLO 1830

Pacific Northwest Laboratory

Richland, Washington 99352 


\begin{abstract}
The Fossil2 energy-economic model is used by the U.S. Department of Energy (DOE) for a variety of energy and environmental policy analyses. A number of improvements to the model are under way or are being considered. This report was prepared by the Pacific Northwest Laboratory (PNL) to provide a clearer understanding of the current industrial sector module of Fossil2 and to explore strategies for improving it. The report includes a detailed description of the structure and decision logic of the industrial sector module, along with results from several simulation exercises to demonstrate the behavior of the module in different policy scenarios and under different values of key model parameters. The cases were run with the Fossil 2 model at PNL using the National Energy Strategy Actions Case of 1991 as the point of departure.

The report also includes a discussion of suggested industrial sector module improvements. These improvements include changes in the way the current model is used; on- and off-line adjustments to some of the model's parameters; and significant changes to include more detail on the industrial processes, technologies, and regions of the country being modeled. The potential benefits and costs of these changes are also discussed.
\end{abstract}




\section{EXECUTIVE SUMMARY}

The Fossil2 energy-economic model was used recently in support of two major analysis efforts at the U.S. Department of Energy (DOE)--the first National Energy Strategy (NES) and the DOE report to Congress, Limiting Net Greenhouse Gas Emissions in the United States. The DOE will continue to use this model for policy analysis, at least in the near term. To support this use, some parts of the model are being improved; but changes to the model's treatment of the industrial sector are not currently planned, although this treatment is generally considered weak. Much of the reason for this belief is a general lack of understanding of the model and of how model parameters are manipulated to simulate the effects of potential policies. The purpose of this report is to provide a clearer understanding of the current industrial sector module of Fossil2 and explore strategies for improving it. This report was prepared by the Pacific Northwest Laboratory for DOE's Office of Industrial Technologies, Conservation and Renewable Energy Program. ${ }^{(a)}$

\section{MODEL DESCRIPTION}

The Fossil2 model is a large-scale, dynamic simulation model of the U.S. energy supply and demand system. The code for the model is written in the DYNAMO systems dynamics programming language. The model simulates the energy marketplace by modeling dynamic stocks and flows for all energy-producing and energy-consuming sectors. The stocks include energy-production facilities (such as oil fields), energy-transformation facilities (such as power plants), and energy-consuming entities (such as houses, vehicies, and manufacturing plants). The flows include energy demand and supply, fuel demand and supply, and prices. Model outputs include detailed projections of U.S. energy supply, energy demand, prices, and environmental emissions over a 40year period (DOE 1991b).

The industrial demand sector is modeled at a highly aggregated level using four industry-wide energy end-use categories: steam, machine drive/electrolytic processes, other process heat, and

(a) Pacific Northwest Laboratory is operated for the U.S. Department of Energy by Battelle Memorial Institute under Contract DE-ACO6-76RLO 1830. 
feedstocks. Industrial cogeneration is considered a subset of steam demand. The industrial sector module has a set of conservation supply curves for each end-use based on specific technologies.

Figure S.1 summarizes the series of steps Fossil2's industrial sector module uses to convert macroeconomic indexes into forecasts of demands for energy services; investments in energy efficiency; market shares for competing fuels; and, finally, actual fuel use. Fossil2 is an integrating model of the U.S. energy system; thus, the decision flow depicted in Figure S.1 does not exist in isolation. For example, fuel consumption in one time increment in the industrial sector affects fuel production, as well as fuel consumption in other end-use sectors, through a system of price feedbacks. In the next time increment, these effects return to the industrial sector through changes in the macroeconomic indexes that begin its logic flow. The feedbacks to the rest of the energy sector modules can therefore be interpreted as completing the circle from the bottom to the top of the flow chart shown in Figure S.1.

Fossil2 measures the demand for energy services in each of the end-use categories in terms of the Btu of useful energy delivered. By definition, the energy service demand would equal actual energy consumption if all equipment were operating at $100 \%$ efficiency. When investments in energy efficiency are undertaken, energy consumption will then be closer to the corresponding energy service demands.

The demand for energy services in each of the four end-use categories is the product of a baseline service demand per unit of industrial production, an aggregate measure of industrial productivity (the Industrial Production Index [IPI]), and a set of product/process change multipliers (PPCMs). Baseline service demand must be set in conjunction with the levels of demand in the year for which the IPI is standardized.

Along with the IPI, the PPCMs are the most critical parameters in modeling energy consumption in Fossil2's industrial sector module. They must incorporate, in a single set of timedependent variables for each end-use service, the aggregate product and process mix of the industrial sector. Because of the high level of aggregation in the industrial sector module, the PPCMs are the only mechanism available for capturing changes in the nation's product mix and evolutions in industrial processes. The PPCMs are specified exogenously to the model and have no endogenous behavior. 


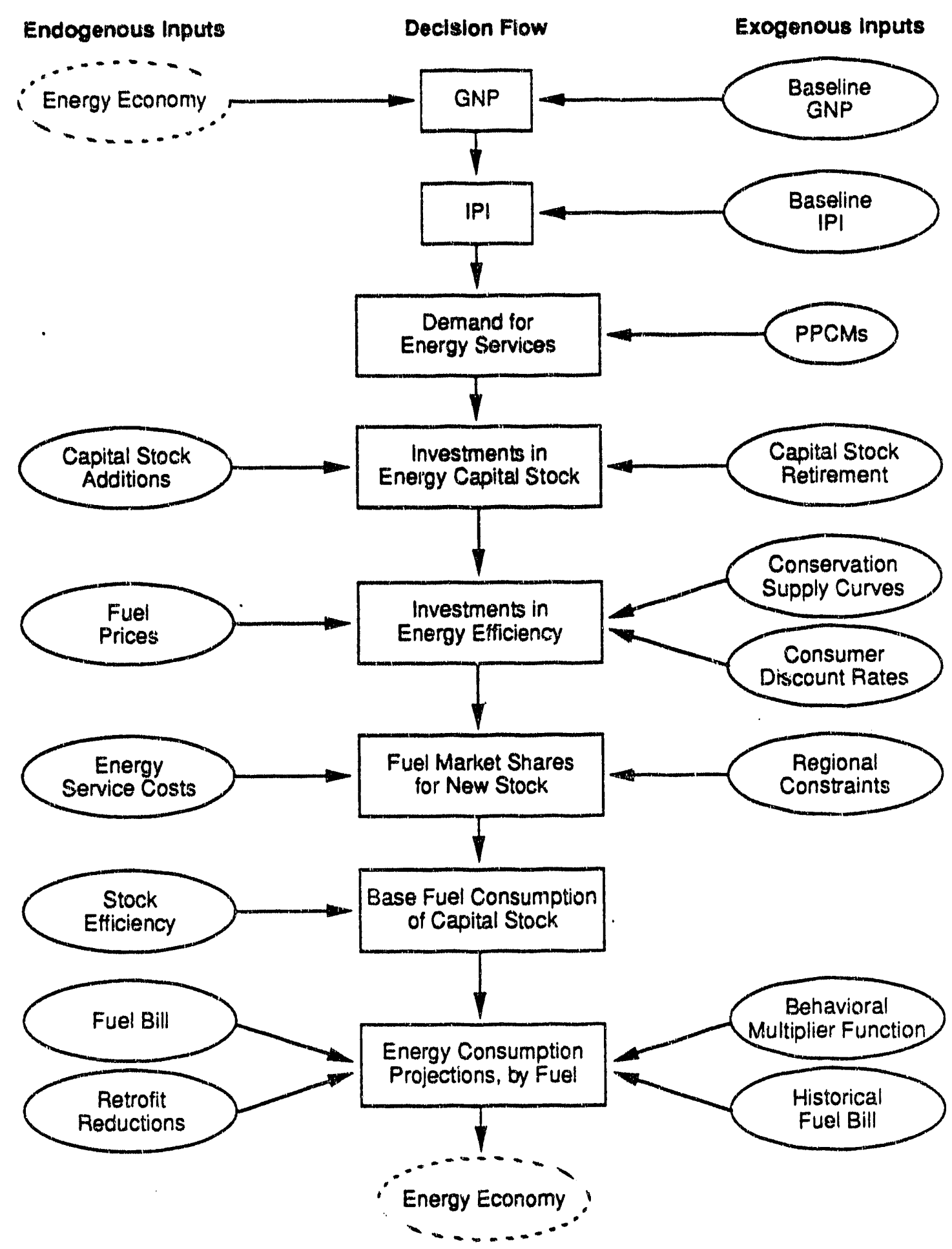

FIGURE S.1. Logic Flow of Fossil2 Industrial Sector 


\section{SMMLATION RUNS}

We performed several simulation exercises to demonstrate the behavior of the Fossil2 industrial module in different policy scenarios and under different values of key model parameters. The cases were run with the Fossil2 model at PNL using the NES Actions Case of 1921 as the point of departure. The cases run are as follows:

- increased fuel prices (carbon taxes up to $\$ 750 / \mathrm{mtC}$ )

- higher and lower discount rates (from 5\% to 33\%)

- accelerated and decelerated capital stock retirement rates (each by $25 \%$ relative to the NES Actions Case)

- removal of the behavioral multiplier effect, which normally captures short-term energy management steps taken in response to fuel price changes

- removal of the effect of retrofits on energy consumption.

Most cases had interesting, and sometimes counterintuitive, impacts on cogeneration use and on total industrial energy use. These cases illustrate well the kinds of analyses for which the Fossil2 model is a useful tool: capturing complex interactions among competing causal factors that might not immediately be obvious to an analyst without the aid of a model.

The types of analyses for which the model is not as well suited, and other model drawbacks, point to strategies for improving both the use of the model and the model itself.

\section{STRATEGIES FOR IMPROVEMENTS IN MODEL USE}

The assumptions and parameter values used in the model should be reported along with the results of an analysis. Off-line calculations or model runs used to derive model inputs to Fossil2 should be clearly described. Reporting of such factors allows the analyst to better interpret for decision-makers the results of exercising the model under various scenarios. Some of the assumptions and parameter values that should be reported are the PPCMs, the behavioral multipliers, the capital stock retirement rates, and the embedded market share constraints on the use of particular fuek.

Additional "policy handles" related to the PPCMs would be a valuable addition to the model. These handles can be provided via off-line analysis tools that can be used to derive the PPCMs. 
For example, a spreadsheet processor could be used to make parametric changes to product mix and industrial production, changes that are then used to modify the PPCMs for input to the model.

The translation of proposed policy actions into changes in model inputs or parameters should also be made clear. Without such a description, the analyst is at a disadvantage in trying to interpret whether the policy was handled appropriately and in presenting results to decision-makers. Modeling the effects of accelerated research and development is of particular interest to CE program managers and policy-makers. Different research and development investment policies are perbaps modeled best using a "scenario analysis" approach, in which a different conservation supply curve for each investment scenario is constructed outside the model. Fossil2 can then be used to test the impact of the inferred technological improvements within its industrial sector framework.

\section{STRATEGIES FOR MORE SUBSTANTIVE CHANGES TO THE MODEL}

One of the major obstacles that confronts an analyst attempting to interpret the results of a Fossil 2 scenario is that he or she is provided only the fuel consumption results. The analyst does not have the information required, for example, to compare two scenarios with different consumption projections and determine how much of the difference in results is due to changes in service demand, in fuel market shares, in energy efficiency, or in some other factor. To remedy this problem, Fossil2 could report the energy efficiencies of the capital stock along with the fuel consumption results for each scenario. Implementing this strategy would require some minor recoding of the model in addition to coordinating with conservation supply curve databases.

The Fossil2 industrial sector module does not distinguish stock by its vintage or age. Because it has no additional information available to it, the model operates as if retiring stock were at the average stock efficiency. Among the implications of this modeling strategy is that the impact of conservation or energy efficiency investments may be systematically understated. This drawback could be addressed by implementing a system of discrete vintages for the capital stock of each fuel and end-use combination. For example, capital stock could be grouped by 5- or 10year blocks. The oldest vintage would be the stock at the assumed maximum capital lifetime, and most of the retirements from stock would come from this vintage. Implementing the discrete 
vintaging system would require a significant effort to collect additional historical data for the industrial sector. A fair amount of recoding of the model would also be required to incorporate the new stock retirement system and to classify parameters such as efficiencies and market shares by vintage. The benefits of the discrete vintaging system would include a greater degree of precision in the model's results, as well as enhanced flexibility in the types of conservation policies that can be tested effectively with the model.

\section{STRATEGIES FOR SIGNIFICANT CHANGES TO THE MODEL}

As currently contigured, energy use in Fossil2's industrial sector module is aggregated into four industry-wide end-uses. If DOE continues to use Fossil2 as a major policy analysis tool, there may be ;ustification for providing a greater level of detail in its industrial sector module. One way to do this would be to organize energy demand by industries rather than by aggregate end-use categories. This could be done by SIC-code industry or by SIC industries reclassified according to their energy use, with the most detailed attention given to the energy-intensive industries. This reorganization would require a substantial effort to collect data and to calibrate the model; however, most of the existing modeling paradigm would still be valid under the new system.

Reorganizing the Fossil2 industrial sector module by industrial classes offers several potential benefits. With a more refined level of detail, the model would be more precise and, possibly, more accurate. The model inputs would be more precisely defined, and the analyst would be provided with a clearer picture of the industrial energy system results as projected by the model. This clearer picture would help the analyst in interpreting the results and supporting them to policy-makers.

A simpler approach to improving the specificity of Fossil2 modeling results is to break out more specific end-uses, such as motors and lighting. Such a reconfiguration would allow easier analysis of specific programs, such as those directed at increasing the capital stock turnover rate (and hence, the adoption rate of more efficient stock) for ubiquitous technologies, such as motors. No fundamental changes to the model structure would be required, although additional conservation supply curves for the new end-uses would be needed. 
Another way to provide more detail in the Fossil2 model is to break its results out according to region. Fossil2 currently models the national energy economy as a single entity; therefore, its assumptions about prices, stocks, resources, etc., are not distinguished by region. Often, policymakers are not concerned solely with the effects of a policy on the nation as a whole: they are also concerned with the effects on various regions of the country. The potential benefits of regionalizing the Fossil2 industrial sector module include the ability to address regional fuel availability and constraints, regional price differences, non-uniform growth in industries across regions, and the impacts of policies on individual regions. Also, the model would operate at a greater degree of precision than the aggregate national model and would provide the anaiyst with more information to support the model's results to policy-makers. The conceptual design for regionalizing Fossil2's industrial sector module would not be difficult, but the scale of effort in terms of collecting data and calibrating the model would increase directly with the number of regions.

\section{FINAL THOUGHTS}

The expected benefits of any specific industrial module development would, of course, have to be judged not only in terms of its own costs, but also in terms of the opportunity costs that impact the development of the rest of the model. Specific changes to the model's industrial sector representation may be desirable themselves, but resources (as well as computer memory) might be better applied to further developing other sectors of the model. Efforts to modify the industrial sector would only be successful if they were coordinated with the development of the other energy sectors in Fossil2. Reorganization of the Fossil2 industrial sector module based on industries or regions would not be warranted if DOE does not plan to use Fossil2 extensively in the future, especially in light of the Energy Information Administration's plans to develop a National Energy Modeling System. 


\section{CONTENTS}

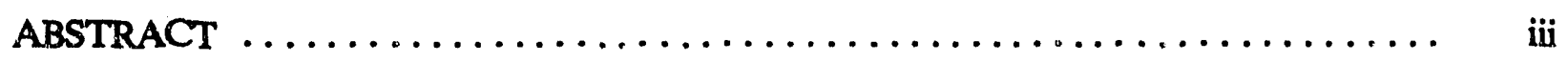

EXECUTTVE SUMMARY $\ldots \ldots \ldots \ldots \ldots \ldots \ldots \ldots \ldots \ldots \ldots \ldots \ldots \ldots, v \ldots \ldots$

1.0 INTRODUCTION $\ldots \ldots \ldots \ldots \ldots \ldots \ldots \ldots \ldots \ldots \ldots \ldots \ldots \ldots \ldots \ldots \ldots, 1.1$

1.1 PURPOSE $\ldots \ldots \ldots \ldots \ldots \ldots \ldots \ldots \ldots \ldots \ldots \ldots \ldots \ldots \ldots \ldots \ldots \ldots \ldots \ldots \ldots \ldots, 1.1$

1.2 OVERVIEW OF THE FOSSIL 2 MODEL $\ldots \ldots \ldots \ldots \ldots \ldots \ldots \ldots, 1.2$

1.3 OVERVIEW OF FOSSI 2'S INDUSTRIAL DEMAND SECTOR MODULE $\ldots \ldots \ldots \ldots \ldots \ldots \ldots \ldots \ldots \ldots \ldots \ldots \ldots \ldots \ldots \ldots \ldots, 1.3$

1.4 MODELING POLICIES WITH THE FOSSIL2 INDUSTRIAL SECTOR $\ldots \ldots \ldots \ldots \ldots \ldots \ldots \ldots \ldots \ldots \ldots \ldots \ldots \ldots \ldots \ldots \ldots, 1.5$

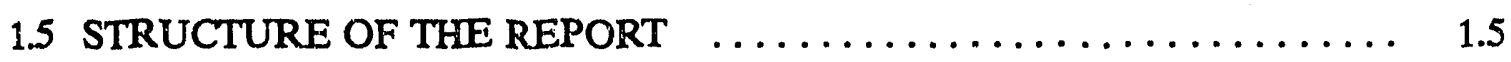

2.0 DESCRIPTION OF THE INDUSTRIAL SECTOR MODULE $\ldots \ldots \ldots \ldots \ldots 2.1$

2.1 THE DEMAND FOR ENERGY SERVICES $\ldots \ldots \ldots \ldots \ldots \ldots \ldots \ldots, 2.1$

2.1.1 Industrial Production Index $\ldots \ldots \ldots \ldots \ldots \ldots \ldots \ldots \ldots .2 .3$

2.1.2 Product/Process Change Multipliers $\ldots \ldots \ldots \ldots \ldots \ldots \ldots \ldots .2 .4$

2.2 INVESTMENTS IN ENERGY EFFICIENCY $\ldots \ldots \ldots \ldots \ldots \ldots \ldots, 2.6$

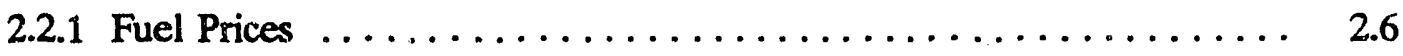

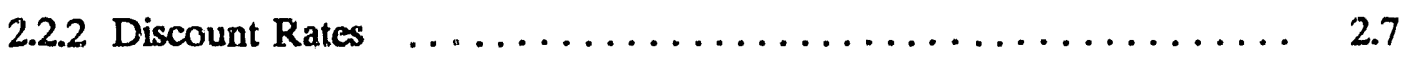

2.2 .3 Conservation Supply Curves $\ldots \ldots \ldots \ldots \ldots \ldots \ldots \ldots \ldots \ldots \ldots \ldots \ldots$

2.2.4 Conservation Investment Decision Algorithms $\ldots \ldots \ldots \ldots \ldots .2 .9$

2.3 MARKET SHARES FOR NEW INVESTMENTS $\ldots \ldots \ldots \ldots \ldots \ldots, 2.11$

2.4 CAPITAL STOCK ADDITIONS AND TURNOVER $\ldots \ldots \ldots \ldots \ldots \ldots 2.13$

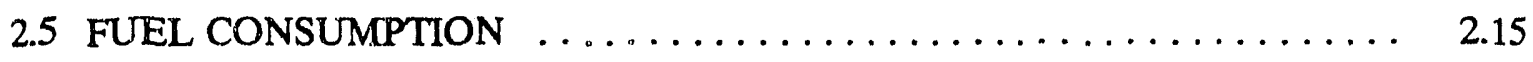

2.5.1 Fuel Consumption of Capital Stock $\ldots \ldots \ldots \ldots \ldots \ldots \ldots \ldots, 2.15$ 
2.5.2 Reduction in Fuel Consumption Due to Retrofits $\ldots \ldots \ldots \ldots \ldots$

2.5 .3 Behavioral Multipliers $\ldots \ldots \ldots \ldots \ldots \ldots \ldots \ldots \ldots \ldots \ldots \ldots$

2.6 TREATMENT OF COGENERATION IN THE MODEL $\ldots \ldots \ldots \ldots \ldots \ldots$

2.7 RENEWABLES $\ldots \ldots \ldots \ldots \ldots \ldots \ldots \ldots \ldots \ldots \ldots \ldots \ldots \ldots \ldots \ldots$

2.8 FEEDSTOCKS $\ldots \ldots \ldots \ldots \ldots \ldots \ldots \ldots \ldots \ldots \ldots \ldots \ldots \ldots \ldots \ldots \ldots$

3.0 RESULTS AND ANALYSIS OF SIMULATION RUNS $\ldots \ldots \ldots \ldots \ldots \ldots \ldots$

3.1 INVESTMENTS IN ENERGY EFFICIENCY AND FUEL MARKET

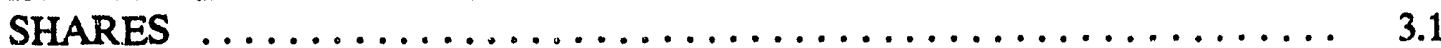

3.1.1 Response to Fuel Prices $\ldots \ldots \ldots \ldots \ldots \ldots \ldots \ldots \ldots \ldots . \ldots \ldots$

3.1.2 Response to Discount Rates $\ldots \ldots \ldots \ldots \ldots \ldots \ldots \ldots \ldots \ldots$

3.2 RETIREMENT RATES $\ldots \ldots \ldots \ldots \ldots \ldots \ldots \ldots \ldots \ldots \ldots \ldots \ldots \ldots$

3.2.1 Deceleration $\ldots \ldots \ldots \ldots \ldots \ldots \ldots \ldots \ldots \ldots \ldots \ldots \ldots \ldots . \ldots \ldots$

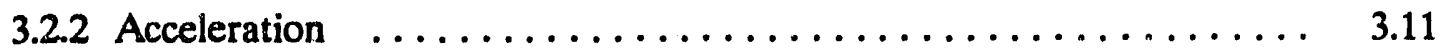

3.3 NO BEHAVIORAL MULTTPLIER CASE $\ldots \ldots \ldots \ldots \ldots \ldots \ldots \ldots \ldots$

3.4 NO RETROFIT CASE $\ldots \ldots \ldots \ldots \ldots \ldots \ldots \ldots \ldots \ldots \ldots \ldots \ldots \ldots \ldots$

4.0 SUGGESTIONS FOR USE AND FURTHER DEVELOPMENT $\ldots \ldots \ldots \ldots$

4.1 STRATEGIES FOR IMPROVEMENTS IN MODEL USE $\ldots \ldots \ldots \ldots \ldots \ldots$

4.1.1 Product-Process Change Multipliers $\ldots \ldots \ldots \ldots \ldots \ldots \ldots \ldots . \ldots .1$

4.1 .2 Other Parameters $\ldots \ldots \ldots \ldots \ldots \ldots \ldots \ldots \ldots \ldots \ldots \ldots \ldots$

4.1.3 Translation of Policies into Model Inputs or Parameter

Changes ............................ 4.4

4.2 STRATEGIES FOR MORE SUBSTANTIVE CHANGES TO THE

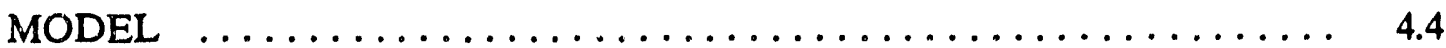

4.2.1 Reporting the Efficiencies of the Capital Stock $\ldots \ldots \ldots \ldots \ldots \ldots 4.4$

4.2.2 Discrete Vintaging of the Capital Stock $\ldots \ldots \ldots \ldots \ldots \ldots . \ldots . \ldots$ 
4.3 STRATEGIES FOR SIGNIFICANT CHANGES TO THE MODEL $\ldots \ldots .4 .7$

4.3.1 Reorganization of Industrial Sector Based on Industries $\ldots \ldots \ldots \ldots \quad 4.7$

4.3.2 Reconfiguration of the Industrial Sector Into More

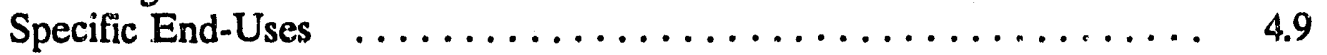

4.3.3 Regionalization $\ldots \ldots \ldots \ldots \ldots \ldots \ldots \ldots \ldots \ldots \ldots \ldots \ldots . . \ldots$

4.4 FINAL THOUGHTS $\ldots \ldots \ldots \ldots \ldots \ldots \ldots \ldots \ldots \ldots \ldots \ldots \ldots \ldots$

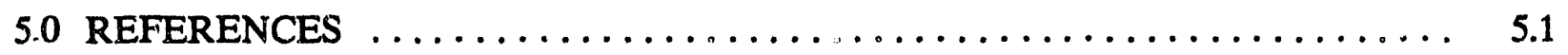

APPENDIX A - DETAILED FOSSIL2 RESULTS FOR VARIOUS CASES $\ldots \ldots \ldots$ A.1 


\section{EIGURES}

S.1 Logic Flow of Fossil2 Industrial Sector $\ldots \ldots \ldots \ldots \ldots \ldots \ldots \ldots \ldots \ldots$ vii

21 Logic Flow of Fossil2 Industrial Sector $\ldots \ldots \ldots \ldots \ldots \ldots \ldots \ldots \ldots \ldots$

22 Example Conservation Supply Curve $\ldots \ldots \ldots \ldots \ldots \ldots \ldots \ldots \ldots \ldots \ldots \ldots$

23 Cost Distribution Functions for Two Competing Options $\ldots \ldots \ldots \ldots \ldots \ldots \ldots$

2.4 Logit Function: Market Shares versus Relative Costs $\ldots \ldots \ldots \ldots \ldots \ldots \ldots \ldots$

3.1 NES Actions Case: Total Industrial Sector Energy Consunption, by Fuel $\ldots . \ldots \quad 3.2$

3.2. \$250/mtC Tax Case: Total Industrial Sector Energy Consumption, by Fuel $\ldots \ldots \quad 3.3$

3.3 Total Industrial Sector Energy Consumption in 2039 versus Carton Tax Rate $\ldots \quad 3.5$

3.4 Total Industrial Sector Eincrgy Consumption in 2030 by Discount Rate $\ldots \ldots \ldots .7$

3.5a 5\% Discount Rate Case: Industrial Sector Energy Consumption, by Fuel $\ldots . \ldots \quad 3.9$

$3.5 \mathrm{~b} 33 \%$ Discount Kate Case: Industrial Sector Energy Consumption, by Fuel $\ldots . . . \quad 3.9$

3.6 Total Industrial Energy Consumption in the Discount Rate Cases $\ldots \ldots \ldots \ldots$

3.T Total Industrial Energy ise for Various Cases $\ldots \ldots \ldots \ldots \ldots \ldots \ldots \ldots \ldots .11$

3.8 Total Cogeneration Energy Use in 2030 for Various Cases . . . . . . . . . . 3.12

3.9 Total Industrial Energy Use for Various Cases $\ldots \ldots \ldots \ldots \ldots \ldots \ldots \ldots \ldots$ 


\section{TABLES}

1.1 Fossil2 Industrial End-Use/Fuel Cosnbinations $\ldots \ldots \ldots \ldots \ldots \ldots \ldots \ldots \ldots$

2.1 Industrial Product/Process Change Multipliers $\ldots \ldots \ldots \ldots \ldots \ldots \ldots \ldots \ldots$

2.2 Capital Lifetime and Discount Rate Assumptions $\ldots \ldots \ldots \ldots \ldots \ldots \ldots \ldots$

2.3 Industrial Feeds 0 cks Assumptions $\ldots \ldots \ldots \ldots \ldots \ldots \ldots \ldots \ldots \ldots \ldots \ldots$

4.1 Summany of Current Foss'12, Development Activities and Sponsors $\ldots \ldots \ldots \ldots$. .

A.1 NES Actions Case - U.S. Industrial Sector Energy Consumption, in Quads ..... A.1

A.2 5\% Discount Rate Case - U.S. Industrial Sector Energy Consumption,

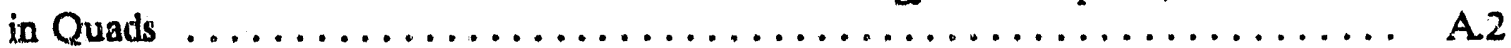

A.3 10\% Discount Rate Case - U.S. Industrial Sector Energy Consumption,

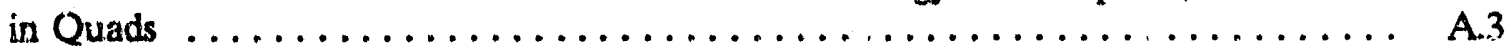

A.4 33\% Discount Rate Case - U.S. Industrial Sector Energy Consumption,

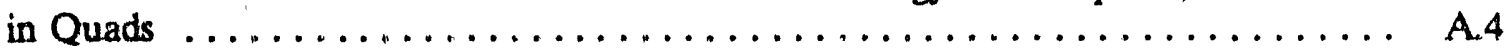

A.5 \$25/mtC Carbon Tax Case - U.S. Industrial Sector Energy Consumption,

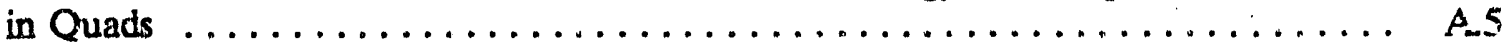

A.6 \$50/mtC Carbon Tax Case - U.S. Industrial Sector Energy Consumption,

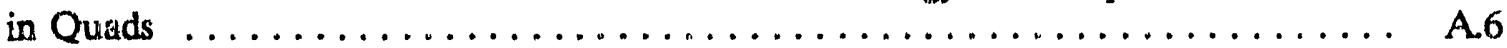

A.7 \$100/mtC Carbon Tax Case - U.S. Industrial Sector Energy Consumption,

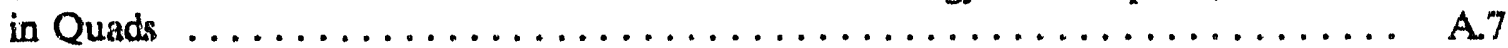

A8 \$250/mtC Carbon Tax Case - U.S. Ine strial Sector Energy Consumption,

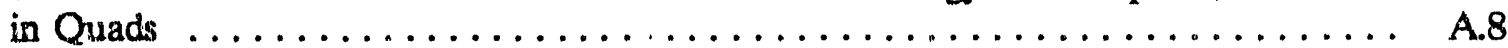

A.9 \$500/mtC Carbon Tax Case - U.S. Industrial Sector Energy Consumption,

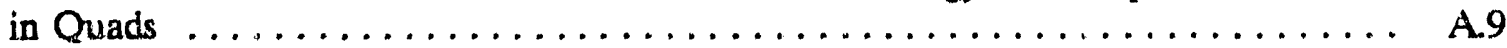

A.10 \$750/mtC Cárbon 'Tax Case - U.S. Industrial Sector Energy Consumption, in Quads ....................................... A.10

A.11 Decelerated Retirement Case - U.S. Industrial Sector Energy Consumption,

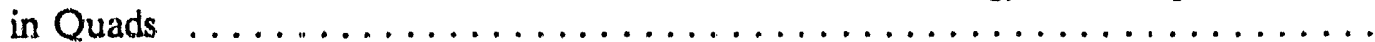

A.12 Accelerated Retirement Case - U.S. Industrial Sector Energy Consumption, in Quads 
A.13 No Behavioral Multiplier Case - U.S. Industrial Sector Energy Consumption, in Quads

A.14 No Retrofits Case - U.S. Industrial Sector Energy Consumption, in Quads 


\subsection{INTRODUCTION}

The Fossil2 energy-economic model was used recently in support of two major analysis efforts at the U.S. Department of Energy (DOE)--the first National Energy Strategy (NES) and the DOE report to Congress, Limiting Net Greenhouse Gas Emissions in the United States (DOE 1991a). At least in the near term, DOE will continue to use this model for policy analyses. In particular, we expect Fossil2 to be used for additional NES analyses beginning in the fall of 1992 .

One of the goals of DOE's Office of Conservation and Renewable Energy (CE) is to provide stronger analytical backup for CE programs and proposed initiatives in the next NES analysis. To this end, some parts of the Fossil2 model are being improved. However, changes in the model's treatment of the industrial sector are not currently planned. A better understanding of Fossil2's industrial energy demand module would help CE, particularly the Office of Industrial Technologies (OIT), analyze the treatment of the indust.12l sector in future DOE policy analysis efforts.

Because the real-world industrial sector is complex and heterogeneous, industrial energy demand is necessarily depicted on a more aggregate level than the other end-use sectors in Fossil2. Nevertheless, Fossil 2's treatment of the industrial sector is generally considered weak. Much of the reason for this belief is a general lack of understanding of the model and of how model parameters are manipulated to simulate the effects of potential policies. In general, the industrial energy demand model's particular strengths, weaknesses, and potential uses are well understood only by the small group of modelers who work with it regularly. Although a full documentation of the model code is now available, it does not assess fully the strengths and weaknesses of the model and is not in a format that can be read and interpreted by policy-makers without substantial effort and a detailed knowledge of the programming language.

\subsection{PURPOSE}

The purpose of this report is to provide a clearer understanding of the current industrial sector module of Fossil2 and to explore options for improving it. The report is intended to inform 
DOE program managers, analysts, and policy-makers about the model and to provide a platform to stimulate further discussion about ways to incorporate industrial sector energy demand into economy-wide energy policy analysis.

\subsection{OVERVIEW OF THE FOSSIL 2 MODEL}

The Fossil2 model is a large-ecale, dynamic simulation model of the U.S. energy supply and demand system. The code for the model is written in the DYNAMO systems dynamics programming language. The model simulates the energy marketplace by modeling dynamic stocks and flows for all energy-producing and energy-consuming sectors. The stocks include energy-production facilities (such as oil fields), energy-transformation facilities (such as power plants), and energy-consuming entities (such as houses, vehicles, and manufacturing plants); the flows include energy demand and supply, fuel demand and supply, and prices. Model outputs include detailed projections of U.S. energy supply, energy demand, prices, and environmental emissions over a 40year period (DOE 1991b).

Because this report focuses on the demand side of the U.S. energy system, the approach to modeling the energy-consuming sectors in Fossil2 is described in more detail here. The four demand sectors (residential buildings, commercial buildings, transportation, and industry) are structured around the concept of energy services. This approach treats energy as a way to provide services (such as space conditioning, lighting, and industrial steam) to final consumers. In each sector, demand for energy services is first determined based on macroeconomic inputs (number of residences, commercial floor space, and industrial production index) and on assumptions about baseline per-unit energy service demand. The final demands for energy services and fuels are then determined based on the assumption that consumers act to minimize their total energy service costs, not just their fuel expenditures. In this framework, the total energy service cost is determined by both the cost of fuel and the capital cost of the technology chosen to provide the energy service. The capital cost component includes incremental costs for conservation measures; the fuel cost component considers energy savings from conservation investments.

In each sector, conservation investments for new equipment in each fuel and end-use combination are calculated based on the assumption that consumers invest in conservation measures up to the point at which the fuel cost savings equal the additional investment. At this point, energy 
service costs for using a given fuel are minimized. For each fuel and end-use pair, a conservation supply curve is incorporated into the model. These curves relate the capital costs of available energy-efficient technologies to the percent energy savings in order of increasing cost (see Chapter 2). These curves provide Fossil2's technological detail in determining the demand sectors' long-term response to fuel price changes.

In each end-use category within a sector, market shares of competing fuels are computed for new equipment. Market shares are based on the relative energy service costs (including base capital cost, incremental cost for conservation, and fuel cost) of each fuel and end-use combination. Market shares are calculated using a standard multinomial logit algorithm. This algorithm captures the variability in costs experienced by consumers so that all investment is not directed at a single least-cost fuel choice (see Chapter 2). Caps are imposed as limits on the maximum market shares of some fuels to reflect regional and logistical constraints on fuel access.

Once market shares of competing fuels are determined, capital stock turnover for energyusing equipment is computed. The model computes fuel consumption based on the efficiency of the existing stock and a cost-driven behavioral multiplier. The multiplier mimics the effect of short-term conservation measures taken in response to price changes. For example, in response to rapid energy price increases, industrial managers implement energy management measures that can be put into place quickly (e.g., steam pipe insulation and boiler adjustments). The multiplier also captures the "take-back" phenomenon that occurs when energy prices are lower than normal.

\subsection{OVERVIEW OF FOSSIL'S INDUSTRIAL DEMAND SECTOR MODULE}

In this section, we briefly introduce the Fossil2 industrial demand module. A more detailed analysis of the module is provided in Chapter 2. The industrial demand sector is modeled using four energy end-use categories: steam, other process heat, machine drive/electrolytic processes, and feedstocks. The model currently uses the end-use category/fuel combinations shown in Table 1.1.

In Fossil2, industrial cogeneration is considered to be a subset of steam demand. Industrial cogeneration is considered to be an energy end-use rather than an energy supply option. 
TABLE 1.1. Fossil2 Industrial End-Use/Fuel Combinations

\begin{tabular}{|c|c|c|c|c|c|}
\hline End-Use & Oil & Gas & Coal & Electricity & Renewables \\
\hline Steam & - & - & - & & - \\
\hline Process Heat & • & - & - & - & \\
\hline Mach. Drive/Electrolytic & - & - & • & - & \\
\hline Feedstocks & - & - & - & & \\
\hline
\end{tabular}

Cogeneration market share, within total steam demand, is a function of cogenerating costs and electricity prices. The electricity produced via cogeneration is subtracted from the total industrial electricity demand.

The industrial sector module has its own set of conservation supply curves for modeling conservation investment in the industrial end-use categories. For steam production, cogeneration competes directly with boilers. Biomass fuel is included in both boilers and cogeneration but is limited to that portion of the industrial market representing the paper and wood products industry. In process heat, coal has a limited market share because impurities prohibit its use in many direct heating applications. Machine drive/electrolytic is primarily an electric category with competition only from self-generation (e.g., diesel generators). Industrial feedstock demands are specified exogenously by fuel type (DOE 1991b).

Base service demand is derived from macroeconomic indices (the GNP and the Industrial Production Index) and a set of product/process change multipliers (PPCMs). The PPCMs are intended to capture the changes in energy intensity (energy service demanded per unit of output) that accompany changes in the mix of industries, products, and industrial processes over time. Changes in industry mix will affect the growth in energy service demands because energy intensity and the types of energy services required vary among industries. Changes in products can have a similar effect; for example, when the chemicals industry shifted from basic chemicals to more refined products, energy service demand increased. Finally, changes in processes reflect major changes in the way products are made. Such changes can have significant effects on energy service demands; for example, the shift from open-hearth furnaces to mini-mills in the steel industry decreased the energy intensity of that industry (DOE 1991b). 


\subsection{MODELING POLICIES WITH THE FOSSIL2 INDUSTRIAL SECTOR}

The effects of various types of regulatory and fiscal policy instruments on energy use in the industrial sector have been modeled with Fossil2 (DOE 1991a,b). For example, efficiency standards in the end-use categories described above can be implemented in the model by specifying "floors" on the conservation supply curves. These floors are minimum levels of energy efficiency that must be met at various points in time. Under these standards, consumers bear the higher costs of the more efficient capital equipment specified by the conservation supply curves.

Another type of policy that has been modeled is accelerated research and development (R\&D) of energy-using equipment in the industrial sector. To model this policy, the conservation supply curves are shifted to the right so that, at each level, energy efficiency is available at a reduced cost. With other things equal, consumers will then be encouraged by the relatively favorable economics to invest in higher levels of energy efficiency. The amount by which the supply curves are shifted is determined outside the model; i.e., no endogenous relationship exists in the model between money spent on R\&D and corresponding improvements in technology performance or cost-effectiveness. This type of relationship is outside the scope of the Fossil2 model.

Finally, the effects of fiscal policies such as taxes and tax credits can also be modeled using the Fossil 2 industrial sector module. Taxes and tax credits, respectively, raise or lower the capital and fuel costs of using energy, changes which in turn affect energy investment and fuel use in the model. Carbon taxes imposed on the combustion of fossil fuels are one type of fiscal policy that has been studied extensively with the Fossil2 model (DOE 1991a).

\subsection{STRUCTURE OF THE REPORT}

Chapter 2 is a critical analysis of the structure of the Fossil 2 industrial sector module, which analyzes in more detail the aspects of the industrial module described in Chapter 1 . Chapter 3 reports the results of exercising the Fossil 2 model under different parametric assumptions to gain more insight into its behavior. Chapter 4 uses the knowledge gained during this effort as a basis for examining options to improve the industrial sector module. The appendix contains detailed results of the Fossil 2 cases discussed in Chapter 3. 


\subsection{DESCRIPTION OF THE INDUSTRIAL SECTOR MODULE}

In this chapter, we offer a step-by-step explanation of the logic flow in the Fossil2 industrial sector module. The discussion is intended to provide an understancing of the basic methodology Fossil2 employs in modeling the U.S. industrial energy system. It is not our goal, however, to provide a comprehensive documentation of every detail in the model code. For that information, the reader is referred to the Fossil2 documented code listing prepared by Applied Energy Services (AES) (1991).

Figure 2.1 summarizes the series of steps Fossil2's industrial sector module uses to convert macroeconomic indexes into demands for energy services, investments in energy efficiency, market shares for competing fuels, and, finally, forecasts of actual fuel use. The figure also illustrates which of the parameters in Fossil2's industrial sector module are computed endogenously in the model and which parameters are specified exogenously and, consequently, have no behavior internal to the model.

Fossil2 is an integrating model of the U.S. energy system; thus, the decision flow depicted in Figure 2.1 does not exist in isolation. For example, through a system of price feedbacks, fuel consumption in one time increment in the industrial sector affects fuel production, as well as fuel consumption, in other end-use sectors. In the next time increment, these effects return to the industrial sector through changes in the macroeconomic indexes that begin its logic flow. The feedbacks to the rest of the energy sector modules can be therefore interpreted as completing the circle from the bottom to the top of the flow chart shown in Figure 2.1.

In the remainder of this chapter, the model's decision steps outlined in Figure 2.1 are explained in greater detail. Included are definitions, derivations of key parameters, and, where appropriate, parameter values that are currently in the model.

\subsection{THE DEMAND FOR ENERGY SERVICES}

Because investments in energy efficiency are an integral part of the Fossil2 modeling paradigm, a distinction must be made within the model between the amount of energy consumed and the amount of energy services derived from that consumption. Fossil 2 measures the demand for energy services in each of the end-use categories in terms of the Btu delivered as useful energy. 


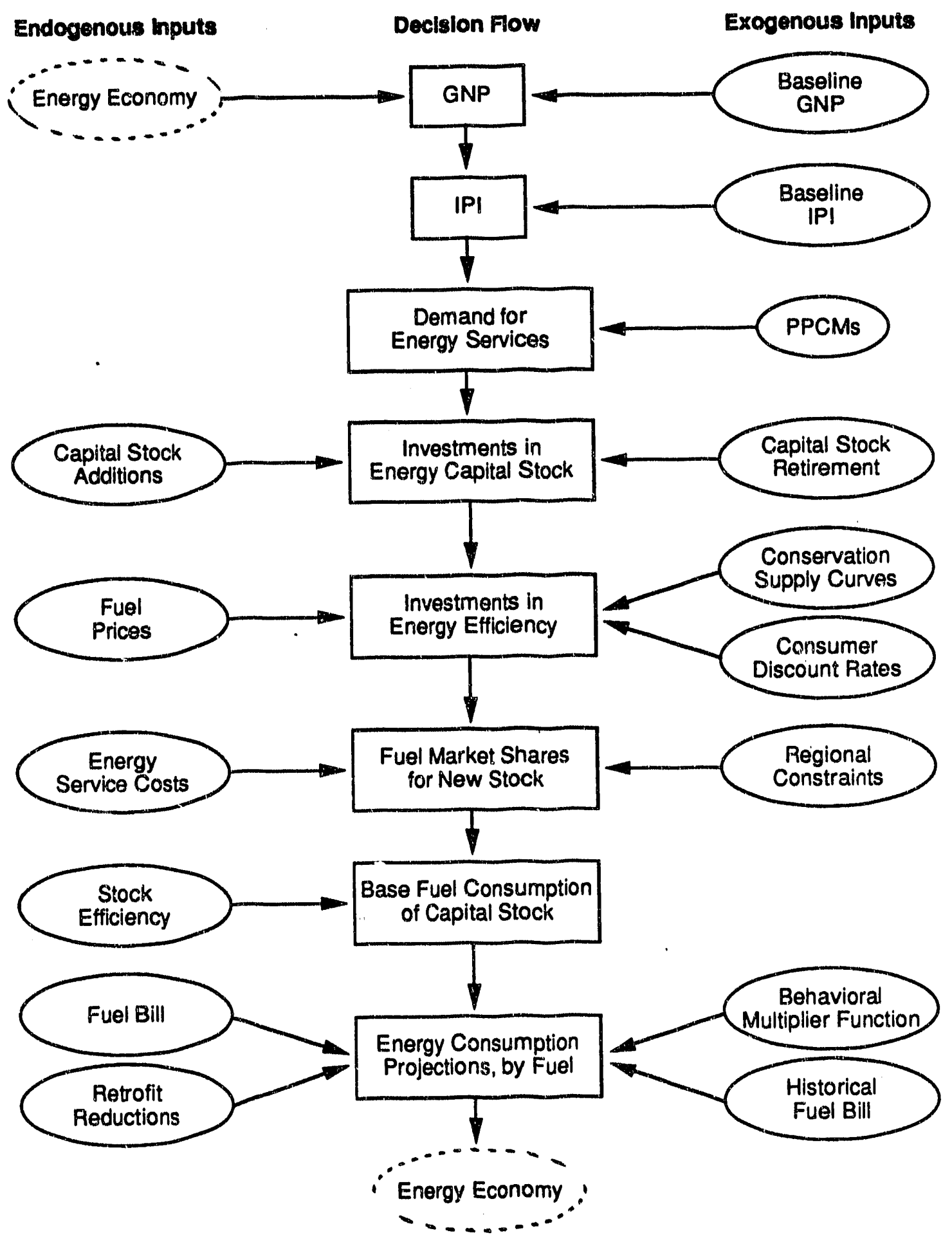

FIGURE 2.1. Logic Flow of Fossil2 Industrial Sector 
By definition, the energy service demand would equal actual energy consumption if all equipment were operating at $100 \%$ efticiency. When investments in energy efficiency are undertaken, the difference between energy consumption and corresponding energy service demands will be decreased.

While its importance might not be immediately obvious, the distinction between energy services and energy consumed is crucial to Fossil2. As will be explained in more detail, the capacity of the energy-consuming capital stock is measured in terms of the level of energy services it can provide, while the actual energy consumption is a function of both energy services and investments in efficiency.

The standard reporting format for the output of a Fossil2 scenario run provides the results in terms of actual energy consumption, rather than energy service demands. Tests have been performed (DOE 1991a), however, to determine how much of the difference in energy consumption between any two scenarios is due to differences in energy efficiency as opposed to differences in energy service demands. The tests indicate that virtually all of the difference could be attributed to investments in energy efficiency. Although there is a slight feedback effect trom GNP to the industrial sector, Fossil2 will not show industrial energy consumers in the long run as willing to do without energy services in response to a policy or increases in price.

In the following sections, we discuss the two most critical parameters in modeling industrial energy consumption in Fossil2: the Industrial Production Index and the Product/Process Change Multipliers.

\subsubsection{Industrial Production Index}

The demands for energy services in the industrial sector are based on an aggregate measure of industrial productivity, the Industrial Production Index (IPI). The IPI is standardized to a value of 100 in 1985. A reference trajectory is set as an exogenous anchor, but the IPI does have a degree of behavioral freedom in the model via a link to GNP in a simple constant elasticity equation of the type shown as Equation $(2.1){ }^{(a)}$

(a) The GNP in Fossil2 also changes slightly in response to changes in the energy sectors. Fossil2 does not have, however, a rigorous national accounting framework from which GNP is constructed. Instead, GNP is modeled as an exogenous time trajectory with an elasticity feedback linking it to the average price of energy. 


$$
\mathrm{IPI}=\mathrm{IPI}_{\mathbf{b}} \cdot \mathrm{GNP}^{\mathbf{a}}
$$

where $\mathrm{IPI}_{\mathrm{b}}=$ the baseline IPI projection

$$
\begin{aligned}
\text { GNP } & =\text { the Gross National Product } \\
\alpha & =\text { the income elasticity of industrial energy demand. }
\end{aligned}
$$

The IPI trajectory used in Fossil2 for the NES analysis is documented, along with other important macroeconomic assumptions, in the NES Technical Annex 2 (DOE 1991b). The elasticity used to relate changes in the IPI to changes in GNP for the NES analysis was 1.4 (AES 1991). Because this value is greater than one, in Fossil2, any change in industrial production relative to a reference trajectory will exceed any change in GNP. This elasticity, which must capture the relationship between GNP and industrial production, is one of the Fossil2 industrial sector module's key parameters, one that must be determined by an analysis external to the model. For past studies, values for this elasticity have been determined through a macroeconomic model that maps the behavioral relationship between industrial output and GNR.

The demand for energy services in each of the four end-use categories is the product of a baseline service demand per unit of industrial production; the IPI; and the Product/Process Change Multipliers, which are discussed next. Baseline service demand must be set in conjunction with the levels of demand in the year for which the IPI is standardized.

\subsubsection{Product/Process Change Multipliers}

Along with the IPI, the Product/Process Change Multipliers (PPCMs) are the most critical parameters in modeling energy consumption in Fossil2's industrial sector module. The degree of aggregation in the Fossil2 model is such that only the demands for similar types of energy services, reaching across all type of industries and manufactured products, are modeled explicitly. (The end-use categories for energy services in the industrial sector are given in Chapter 1.) In other words, energy use is not classified by SIC code or any similar product distinction. Because of this type of aggregation, the PPCMs are the only mechanism available in Fossil2 for capturing changes in the nation's product mix and evolutions in industrial processes.

Equation (2.2) shows how the energy service demand for end-use $i\left(E S D_{\mathrm{i}}\right)$ is derived from the IPI and the PPCM. 


$$
\mathrm{ESD}_{i}=\mathrm{BESD}_{i} \cdot \mathrm{PPCM}_{i} \cdot \mathrm{IPI}
$$

where $B E S D_{i}=$ the base energy service demand per unit of industrial production

$\mathrm{PPCM}_{\mathrm{i}}=$ the Product/Process Change Multiplier for end-use $i$

IPI $=$ is the Industrial Production Index.

The PPCMs are specified exogenously to the model and have no endogenous behavior.

Although these parameters are critical to the model, their function may be relatively opaque to the user. The PPCMs must incorporate, in a single set of time-dependent parameters for each end-use service, the aggregate product and process mix of the industrial sector. Table 2.1 shows the values of the PPCMs that were used in the NES analysis. Thus, the values used in the NES analysis reflect the projection that the amount of energy required per unit of output will decrease somewhat over time in the steam/cogeneration and process heat energy service categories, but will increase in the machine drive/electrolytic category. The latter reflects the expectation that industry will increasingly rely on electricity.

The exogenous PPCMs limit the types of analyses that should be performed with the Fossil2 industrial sector model. Fossil2 cannot predict the effect of an energy policy on the product mix. For example, under a policy that creates high electricity prices, one would expect some shift away from electricity-intensive industries such as aluminum production. Fossil2 cannot reflect this type

\section{TABLE 2.1. Industrial Product/Process Change Multipliers}

\begin{tabular}{cccc} 
Year & $\begin{array}{c}\text { Steam/Cogeneration } \\
(1980=1.00)\end{array}$ & $\begin{array}{c}\text { Machine Drive/Electrolytic } \\
(1980=1.00)\end{array}$ & $\begin{array}{c}\text { Process Head } \\
(1980=1.00)\end{array}$ \\
\cline { 2 - 3 } 1990 & 0.60 & 1.00 & \\
2000 & 0.53 & 1.04 & 0.81 \\
2010 & 0.50 & 1.11 & 0.81 \\
2020 & 0.50 & 1.15 & 0.78 \\
2030 & 0.50 & 1.16 & 0.69 \\
& & & 0.69
\end{tabular}

Source: DOE 1991b. 
of effect endogenously. In this example, the Fossil2 industrial sector would continue to produce as much aluminum as in a low-electricity price scenario. It would, however, produce this aluminum as efficiently as possible.

For past studies, the values of the PPCMs have been computed formally using macroeconomic models in conjunction with an industrial sector model having detail at the SIC level. From these models, the relationship between industrial production and industrial energy service demands is found. The PPCMs are then the coefficients that relate the demands for energy services to the overall IPI. In other studies (including the NES analysis), the PPCMs were used to match industrial forecasts from analyses performed by Energy Information Administration (EIA) models. Because the PPCMs are specified at such an aggregate level of detail, it is difficult to infer an industry or policy perspective in understanding the values (this issues is discussed in Chapter 4).

\subsection{INVESTMENTS IN ENERGY EFEICIENCY}

As discussed earlier, energy service demands are just one factor Fossil2 incorporates in determining energy consumption. The Fossil2 industrial sector module also computes investments in energy efficient capital (also referred to as conservation in the model) on an economic basis. In this section, energy consumers in Fossil2 are modeled as investing in energy efficiency to minimize energy service costs, considering fuel prices, consumer hurdles or discount rates, and capital costs of energy-consuming equipment. We next discuss how fuel prices are calculated in the industrial module, the discount rates that are used, and two concepts critical to understanding how Fossil2 model investment in energy efficiency: conservation supply curves and the conservation investment decision algorithm.

\subsubsection{Fuel Prices}

Fossil2 calculates sector-specific fuel prices as the sum of fuel prices at the point of resource and sector-specific mark-up and transportation charges. The mark-ups to delivered prices are based on a regression analysis relating resource prices to delivered prices (AES 1991). Any 
energy taxes will also be incorporated into these prices. The resource prices are determined in the supply sectors of Fossil2 and are set to approach a supply-demand balance. ${ }^{(a)}$

\subsection{Discount Rates}

Each end-use has a specific discount rate that is used in the decisions for investing in higher levels of energy efficiency. These discount rates are often referred to as "hurdle rates" because they are relatively high and reflect more than just the cost of capital. The hurdle rates function to capture a great deal of consumer behavior phenomena such as limited cash availability, consumer resistance, hiciden costs, and uncertainty. Discount rates and capital lifetime assumptions used in the NES are shown in Table 2.2.

\subsubsection{Cunservation Supply Curves}

A conservation supply curve relates energy efficiency to the corresponding capital cost of available energy technologies. Each fuei and end-use combination in the Fossil2 industrial sector module uses a unique conservation supply curve to mode' the relationship between the marginal cost of investing in energy efficiency versus the degree of energy efficiency obtained. The conservation supply curves used for the NES analysis are depicted in the NES Techrical Annex 2 (DOE 1991b).

TABLE 22. Capital Lifetime and Discount Rate Assumptions

End-Use Category

Steam

Process Heat

Machinc Drive/Electrolytic

Cogeneration

\section{Capital}

Lifetime (yrs)
25

25

20

25
Consumer

Discount Rate

Source: DOE 1991b.

(a) Fossil2, does not balance supply and demand as a strict economic equilibrium, but instead acts as a "cobweb" model with differential equations leading the price trajectory over tinie towards a market clearing set of prices. However, this method is equivalent to a strict equilibrium as the solution interval approaches zero. 
The traditional method of constructing a conservation supply curve is to assemble a list of available technologies, along with their energy efficiencies, in order of ascending first cost. A conservation supply curve created in this manner would hook like the function shown in Figure 2.2, becoming vertical as the list of available technologies is exhausted. This technology-based approach to the supply curves is used in the other demand sectors in Fossil2, and it has been used in the past for the industrial sector.

Because of the heterogeneity of the industrial sector and the aggregate nature of the industrial energy end-uses in Fossil2, the perfect substitutability between technologies implied in the technology-based supply curves may be an oversimplification. For the NES analysis, an alternative method was employed for constructing the conservation supply curves. Instead of examining costs and performance data of different technologies, an empirical relationship between energy prices and energy consumption was found by examining energy consumption at representative industrial facilities that experienced differing energy prices.

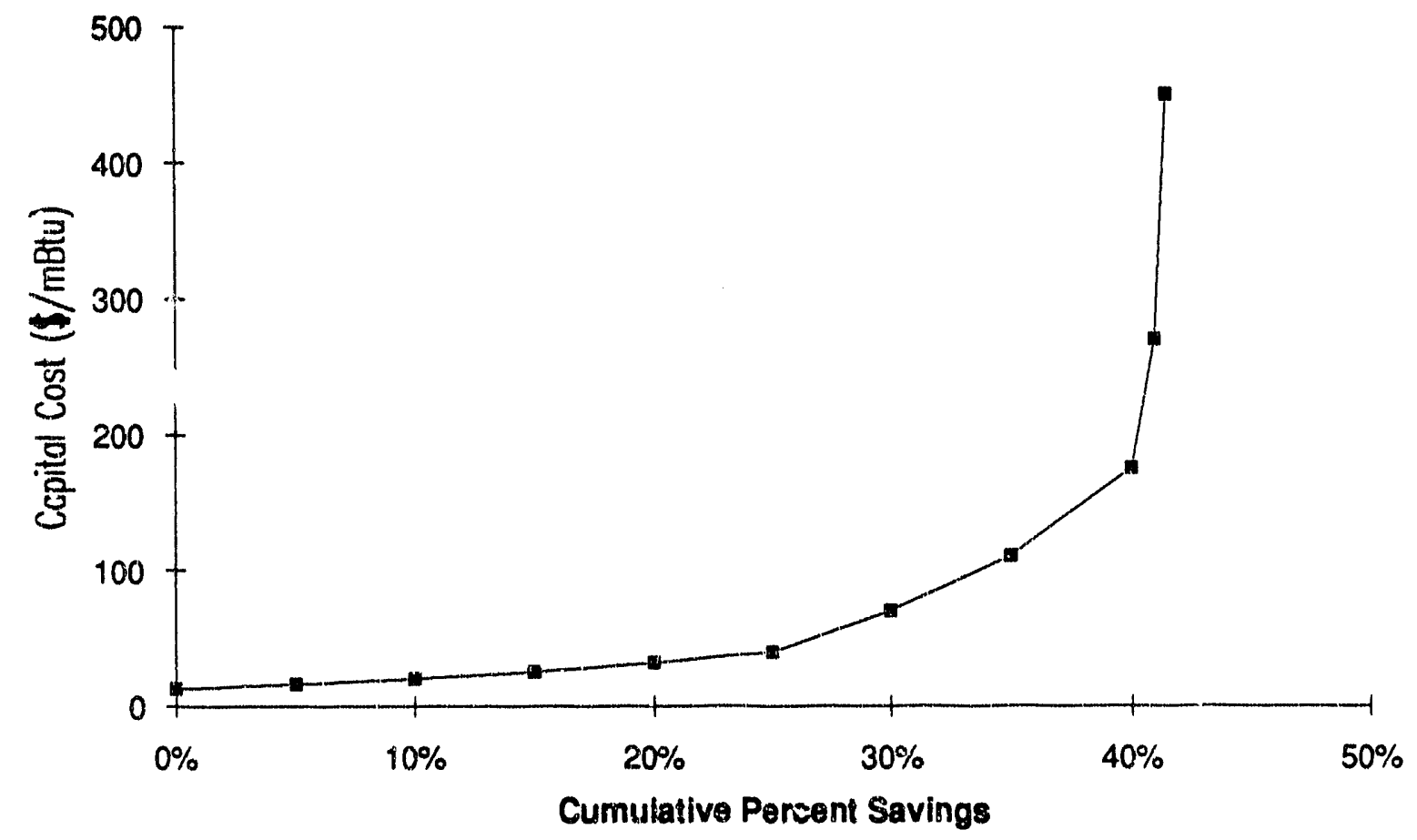

FIGURE 2.2. Example Conservation Supply Curve 


\subsubsection{Conservation Investment Decision Alporithms}

In Fossil2, consumers are assumed to invest in energy-consuming equipment that will minimize their energy service costs. That is, considering fuel prices and discount rates, consumers will purchase energy equipment that will minimize their total annualized costs of capital and fuel. These costs are minimized when investment in energy efficiency or conservation reaches the point at which the cost of saving the next unit of energy equals the cost of consuming that additional unit of energy. Investing less than this amount would result in fuel costs that could have been avoided by paying for more efficiency. Investing more than this amount would result in a capital cost that is too high to be recovered by the resulting fuel savinge.

This minimum cost point follows directly from the first order conditions for cost minimization (from differential calculus). Consider a production function $f(\vec{x})$ with two factor inputs, $x_{1}$ and $x_{2}$. In the conservation investment decision, $f(\vec{x})$ represents the delivered energy service, while $x_{1}$ and $x_{2}$ are energy consumption and conservation investments, respectively. The energy consumer will choose the mix of conservation investments and energy consumption that will result in the lowest energy service cost. Cost minimization is achieved when the technical rate of substitution between fuel consumption and investments in energy efficiency is equal to the economic rate of substitution between the two factors (Varian 1984). In other words, the ratio of the marginal products of the two factors equals the ratio of the marginal costs. The first order minimum cost condition is thus

$$
\frac{\frac{\partial f(x)}{\partial x_{1}}}{\frac{\partial f(\bar{x})}{\partial x_{2}}}=\frac{w_{1}}{w_{2}}
$$

where $\partial f(\vec{x}) / \partial x_{1}=$ the marginal product of energy consumption, which is equal to the energy efficiency, referred to as $E F F$ in the equations that follow

$\partial f(\vec{x}) / \partial x_{2}=$ the marginal product of the conservation investment, i.e., the amount of energy service demand met by an additional unit of investment in conservation, referred to as $M P_{\text {cons }}$ in the equations that follow

$w_{1}=$ the fuel price, which will be denoted $P_{f}$, a constant 


$$
\begin{gathered}
w_{2}=\text { the marginal cost of conservation, which will increase directly with the } \\
\text { amount of efficiency gained, and will be referred to as } M C_{\text {cons. }}
\end{gathered}
$$

By substituting and rearranging terms in Equation (2.3), we can state the minimum cost expression as

$$
\frac{\mathrm{MC}_{\text {cons }}}{\mathrm{MP} \text { cons }}=\frac{\mathrm{P}_{\mathrm{f}}}{\mathrm{EFF}}
$$

One additional step is required to get the expression in Equation (2.4) in the form used in Fossil2. In order for Fossil2 to allow for different values of consumer hurdle rates, a capital recovery factor $(C R F)$ or annualization factor, which is a function of both the discount rate and the capital lifetime, is applied to the marginal cost of the investment and incorporated into the minimum cost expression as shown in Equation (2.5). ${ }^{(a)}$

$$
\frac{\mathrm{MC}_{\text {cons }}}{\mathrm{MP}_{\text {cons }}}=\frac{\mathrm{P}_{\mathrm{f}}}{\mathrm{EFF} \cdot \mathrm{CRF}}
$$

Fossil2 computes the right side of Equation (2.5) and compares this value to the corresponding conservation supply curve for the appropriate end-use and fuel combination. The left side of the equation represents the values that ise plotted on the $\mathrm{X}$ axis of the conservation supply curve. The $\mathrm{X}$ axis of the supply curve gives the amount of energy efficiency gained relative to a base efficiency at each level of investment.

The optimal level of conservation investment is computed for each fuel in each end-use. Based on these investment costs and corresponding fuel costs (at the computed efficiencies), an average energy service cost per million Btu is calculated for each fuel and end-use combination. These energy service costs are then used to determine the fuel market shares for new investment. in each end-use category.

(a) Note that because the values in Fossil2's conservation supply curves are first costs (i.e., the costs are not annualized), they will appear higher than other conservation supply curves that show only the relationship between energy price and conservation investraent (with an assumed annualization factor already incorporated into the curve). 


\subsection{MARKET SHARES FOR NEW INVESTMENTS}

For each energy end-use category, the fuel market shares for new investments is determined by the relative energy service costs of the competing fuels. Because the market shares calculation is for new investments, fuel prices can affect the overall market shares for fuels only at the margin. The fuel market shares for existing stock are a function of past investment decisions and, thus, past fuel prices.

In general, the market share determination is based on the assumption that, ceterus parabis, energy consumers will invest in the fuel choice with the lowest associated energy service cost. In determining market shares, Fossil2 recognizes that, realistically, consumers will face varying costs in different areas or in different situations. To account for this variability, Fossil2 uses cost distribution functions, rather than point estimates of costs, in computing market shares of competing fuels.

Figure 2.3 depicts cost distribution functions for two competing fuels. Based on the mean costs only, fuel choice 1 would capture the entire market. Because of the variability in costs, however, the cost distribution curves overlap, creating a region in which fuel choice 2 will cost less than fuel choice 1 and therefore receive a portion of the market share.

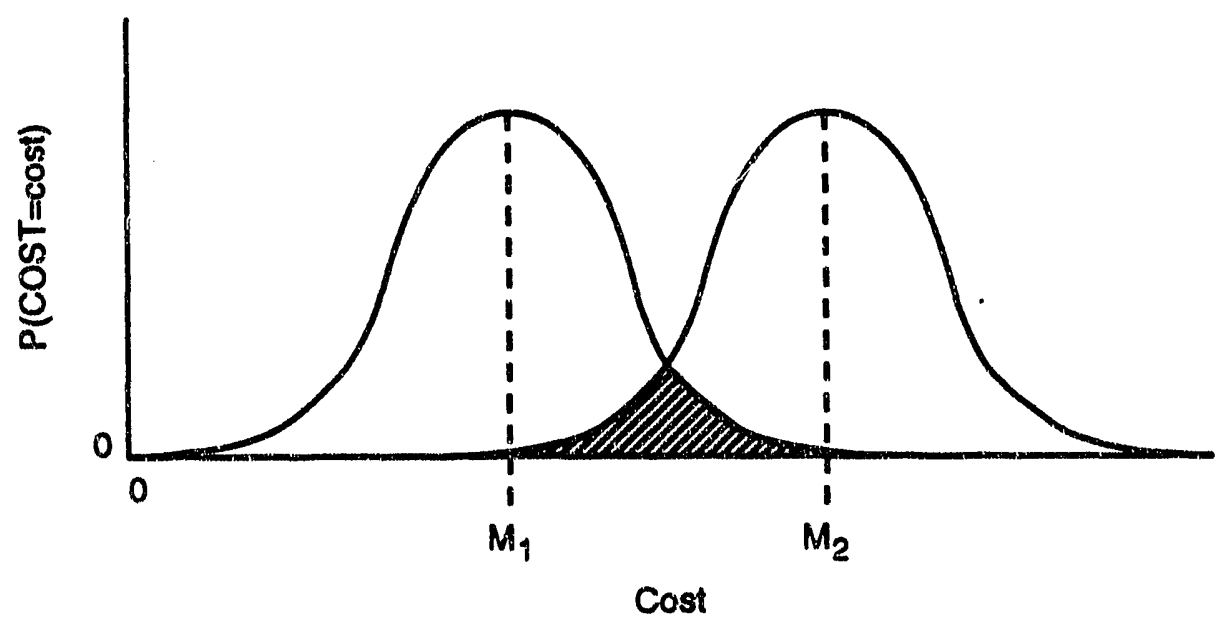

FIGURE 2.3. Cost Distribution Functions for Two Competing Options 
The functional form for calculating market shares based on these cost distribution functions is a multinomial logit equation. The logit equation methodology, which can be derived from cost distributions having the functional form of a Weibull probability density function, has been used in several energy models for computing market shares (Edmonds and Reilly 1985). The logit equation has the desired behavioral properties that the resulting shares will always add to unity, and competing fuels with higher costs will have lower shares than those with lower costs. Equation (2.6) is the logit expression for market shares of competing fuels.

$$
s_{i, f}=\frac{E S C_{i, f}^{-\lambda}}{\sum_{j=1}^{n f_{i}} E S C_{i, j}^{-\lambda}}
$$

where $\mathrm{s}_{\mathrm{i}, \mathrm{f}}=$ the market share of fuel $f$ in end-use $i$

$$
\begin{aligned}
E S C_{\mathrm{i}, \mathrm{f}} & =\text { the energy service cost for fuel } f \text { in end-use } i \\
\lambda & =\text { the cost distribution parameter } \\
n f_{\mathrm{i}} & =\text { the number of competing fuels in energy end-use } i .
\end{aligned}
$$

The exponent parameter in the logit equation, $\lambda$, reflects the steepness of the cost distribution functions. That is, a smaller parameter value means that cost distribution functions are relatively flat, with the resulting market shares relatively insensitive to minor differences in costs of competing fuels. Conversely, a higher parameter value will result in a rapid shift of market share to the least-cost fuel. The values of $\lambda$ used currently in Fossil2 are 6 for industrial steam and 8 for other process heat and machine drive/electrolytic processes (AES 1991). Figure 2.4 shows market shares for two competing factors under different values of the cost distribution parameter.

In the market share allocations, Fossil2 does account for some regional and logistical constraints on fuel availability and appropriateness. For example, inherent maxima for natural gas and renewables market shares reflect the fact that these fuels are not available in all areas. Also, coal is constrained since it is not feasible to use coal in some applications. 


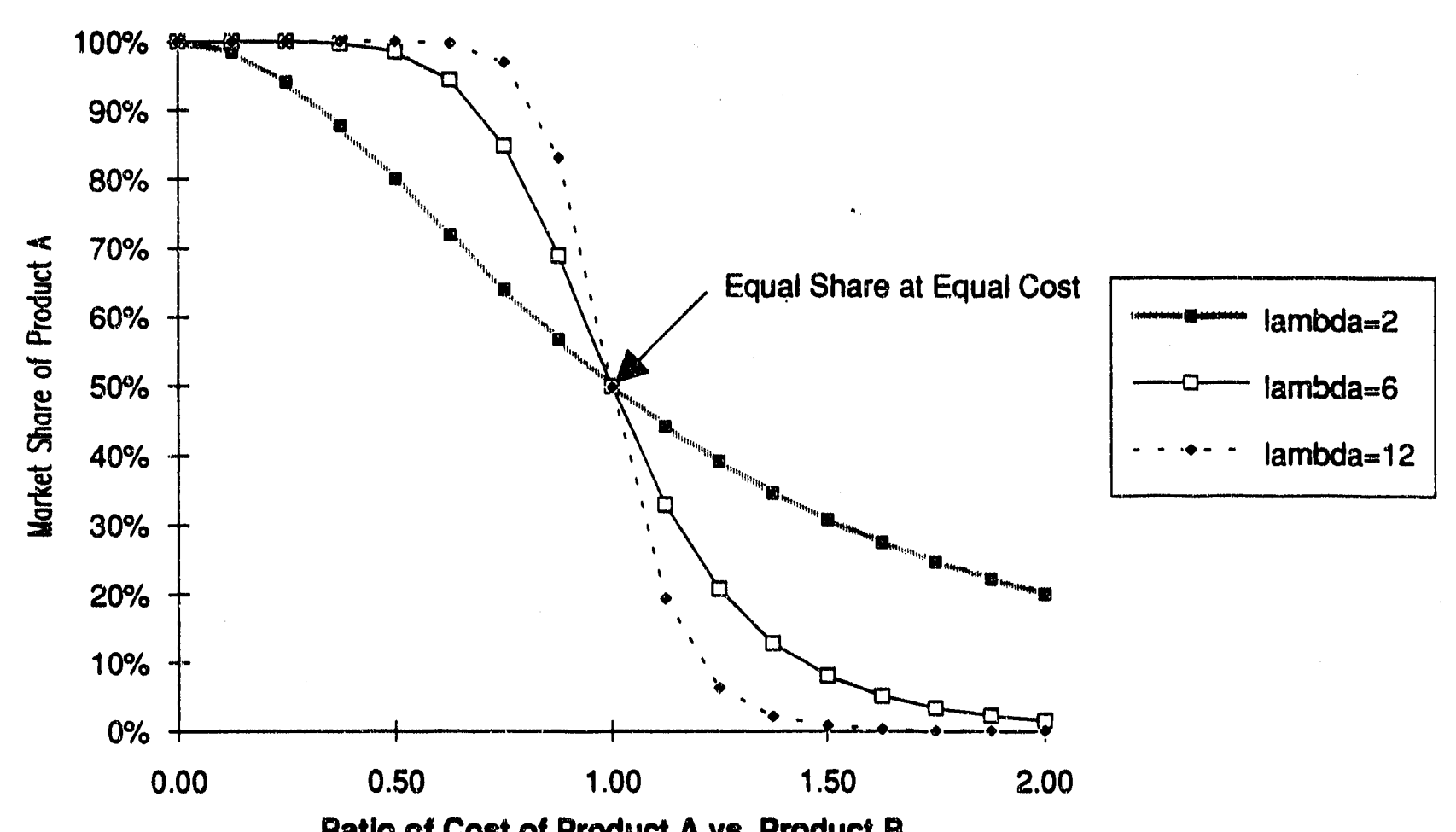

FIGURE 2.4. Logit Function: Market Shares versus Relative Costs

\subsection{CAPITAL STOCK ADDITIONS AND TURNOVER}

Fossil2 tracks the level of energy capital stock in operation for each of the end-use and fuel combinations in its industrial sector module, with the exception of feedstocks. Because of the distinction in the model between energy services delivered and actual energy consumption, a pair of quantities is required for characterizing the capital stock of each end-use and fuel combination. The first quantity tracked is the energy-services-delivering capacity of the capital stock, while the second quantity is the corresponding fuel consumption of that capital stock. These quantities are discussed in the next section; here, we describe how the capital stock is tracked.

The Fossil2 industrial sector tracks energy-consuming rapital stock, accounting for additions to and retirements from the stock over time. Although Fossil2 employs a capital stock vintaging system, the use of the term "vintaging" may be misleading in this context because the capital stock 
is modeled as a continuous variable. In other words, there is no discrete vintaging of the stock; instead, a single quantity is used to represent the existing capital stock for a specific fuel in each end-use.

The required investment in new stock for an energy end-use is a function of three factors: the demand for energy services, the capacity of the existing stock, and retirements from existing stock. Equation (2.7) shows this relationship.

$$
\text { NewStock }_{i}=E S D_{i}-S T_{i}+R T_{i}
$$

where NewStock $=$ the investment in capital stock for end-use $i$

$$
\begin{aligned}
\mathrm{ESD}_{\mathrm{i}} & =\text { the energy service demand for end-use } i \\
\mathrm{ST}_{i} & =\text { the existing stock for end-use } i \\
\mathrm{RT}_{\mathrm{i}} & =\text { the retirements from existing stock for end-use } i
\end{aligned}
$$

The energy service demand is computed as in Equation (2.2). The existing stock is a function of the previous period's investments, retirements, and existing stock. Because the capital stock is specified as a single quantity, the method used for computing retirements from stock is to assume that the amount of capital stock retired is directly proportional to the amount of capital stock in place. This formulation results in an exponentially decaying amount of capital stock, replenished by new investments. The expression for retirements is given in Equation (2.8).

$$
\mathrm{RT}_{\mathrm{i}}=\mathrm{ST}_{\mathrm{i}} \cdot \mathrm{RR}_{\mathrm{i}}
$$

where $\mathrm{RR}_{\mathrm{i}}=$ the retirement rate for end-use $i$.

With the required amount of new capital stock determined for an end-use, the investment is then allocated to the competing fuels based on the market shares computed in Equation (2.6). As Equation (2.9) shows, investment in each fuel is the product of that fuel's market share and the required investment in the end-use. 


$$
\text { NewStock }_{\mathrm{i}, \mathrm{f}}=\mathrm{s}_{\mathrm{i}, \mathrm{f}} \cdot \text { NewStock }_{\mathrm{i}}
$$

where NewStock $_{\mathrm{i}, \mathrm{f}}=$ the new capitai stock for fuel $f$ in end-use $i$.

This method of tracking capital stock as continuous variables with retirements determined by exponential decay rates has several implications in the model. One result is that the model does not distinguish older stock from newer stock. The model cannot proceed over time, therefore, by retiring the oldest stock first in each time period, although this operating mode is implied to some extent in the model's handling of fuel consumption. In addition, the retirement rates are specified exogenously to the model, so early or late retirements on an economic basis are not considered. (See Table 2.2 for capital lifetime assumptions.)

\subsection{FUEL CONSUMPTION}

The final computations made by Fossil2's industrial module lead to its projections of the fuel consumed in each energy end-use. Fuel consumption is determined by three factors: the fuel consumption of the capital stock, the reductions in fuel consumption from retrofits of existing stock, and a behavioral multiplier based on fuel bills relative to a base.

\subsubsection{Fuel Consumption of Capital Stock}

As discussed in the section on capital stock turnover, Fossil2 maintains a set of fuel consumption variables that serve a complementary function to the capital stock variables. These variables track the total fuel consumption of the capital stock in each fuel and end-use category. They are treated analogously to the capital stock variables in that fuel consumption is added to the total as new investments are made and is subtracted as stock retires. Equation (2.10) shows this relationship. 


$$
\text { Fuelstk }_{\mathrm{i}, \mathrm{f}, \mathrm{t}}=\text { Fuelstk }_{\mathrm{i}, \mathrm{f}, \mathrm{t}-1}+\frac{\text { NewStock }_{\mathrm{i}, \mathrm{f}, \mathrm{t}}}{\mathrm{MEFF}_{\mathrm{i}, \mathrm{f}, \mathrm{t}}}-\text { Fuelstk }_{\mathrm{i}, \mathrm{f}, \mathrm{t}-1} \cdot \mathbf{R R}_{\mathrm{i}}
$$

where NewStock $_{1, f}=$ the new capital stock for fuel $f$ in end-use $i$

$$
\mathrm{RR}_{\mathrm{i}}=\text { the retirement rate for end-use } i
$$

Fuelstk $_{\mathrm{i}, \mathrm{f}}=$ the stock of total fuel consumption for fuel $f$ in end-use $i$

$\mathrm{MEFF}_{\mathrm{i}, \mathrm{f}}=$ the marginal efficiency (determined by the investments in conservation) for fuel $f$ and end-use $i$

$t=$ the time index.

Note from Equation (2.10) that additions to the fuel consumption total are a function of the conservation investment decisions. For example, greater investment in energy efficiency will result in a smaller amount added to the fuel consumption total for a specified energy services capacity. Note also the computation of retirements from total fuel consumption. Fossil2 assumes that fuel consumption from existing stock decreases at the same rate at which the capital stock retires. This result can be explained as one part underlying assumption and two parts modeling artifact. The underlying assumption here is that, by the time it reaches retirement, the capital stock will have been operated and maintained to a point at which it is generally no better or worse than the rest of the capital stock. The result is perhaps better explained as an artifact of the modeling system. Fossil2 is a continuous systems dynamics model, and capital stock is tracked as a continuous entity (i.e., there is no discrete vintaging of capital stocks). Once capital stock is added to the pool of existing stock, it loses its identity; Fossil2 does not distinguish older stock from newer stock. Therefore, a reasonable assumption, albeit the only assumption possible given the information in the model, is that the retiring capital stock is of average energy efficiency.

\subsubsection{Reduction in Fuel Consumption Due to Retrofits}

Fossil 2 accounts for the fact that, as fuel prices rise, the efficiency of existing energy-consuming capital stock will be upgraded. For each fuel and end-use pair, Fossil2's industrial sector module incorporates efficiency-enhancing retrofits of capital stock as reductions in the value of total fuel consumption stated in Equation (2.10). Again, given the continuous structure of the 
capital stock and fuel variables, a reasonable, but arguably ad hoc, method is used for determining the amount of fuel saved from retrofits.

For each fuel and end-use, a "target" efficiency for retrofits is computed. The target efficiency is a function of the efficiency of the new stock and an efficiency taken from conservation supply curves created especially for retrofits of stock. The latter stock is assumed to be in place before the beginning of the model's simulation period. In the model, the efficiency of the capital stock in a given period will move, through the retrofit mechanism, toward the efficiency of the new stock being added in that period. This movement, however, lags behind the new stock's efficiency by a constant delay factor. Equation (2.11) is a representative expression for the reduction in fuel consumption from retrofits.

$$
\text { Fuelstk }_{i, f, t}=\text { Fuelstk }_{i, f, t}-\frac{\text { Fuelst }_{i, f, t}-\frac{S T_{i, f, t}}{\operatorname{TEFF}_{i, f, t}}}{\text { Delay }_{i}}
$$

where Fuelstk $\mathrm{i}_{\mathrm{i}, \mathrm{f}}=$ the stock of total fuel consumption for fuel $f$ in end-use $i$ first computed in Equation (2.10)

$$
\begin{aligned}
\mathrm{TEFF}_{\mathrm{i}, \mathrm{f}} & =\text { the target efficiency of retrofits } \\
\mathrm{ST}_{\mathrm{i}, \mathrm{f}} & =\text { the existing stock for fuel } f \text { and end-use } i \\
\text { Delay }_{\mathrm{i}} & =\text { the retrofit delay factor for end-use } i \\
\mathrm{t} & =\text { the time index. }
\end{aligned}
$$

While this approach may be lacking a rigorous foundation, it does have an intuitive explanation and is actually a clever way to incorporate the important phenomenon of retrofits, given the constraints of the model programming paradigm. The retrofit delay term was assumed in the NES

(a) For a complete representation of the computation of target efficiencies for retrofits, see the Fossil2 Documented Code Listing (AES 1991). 
analysis to be ten years for the industrial sector energy end-uses (AES 1991). The impact of Fossil2's treatment of retrofits on industrial energy consumption projections will be examined empirically in the next chapter.

To reiterate what is stated by Equations (2.10) and (2.11), additions to and removals from the total fuel consumption of the existing capital stock are determined based on the marginal efficiency and the average efficiency, respectively. Next, any reductions in total fuel consumption due to retrofits of the existing capital stock are computed. The final factor in computing fuel consumption is the behavioral multiplier, which is discussed next.

\subsubsection{Behavioral Multipliers}

While long-term elasticity of energy demand behavior in Fossil2 is captured through the conservation investment and market share algorithms, the behavioral multipliers function to capture the short-term elasticity behavior in the model. This short-term behavior reflects decisions to do without some energy services when fuel bills are relatively high, as well as decisions to demand more energy services when fuel bills are rel... aly low. An expression for fuel consumption with the behavioral multipliers is given as Equation (2.12).

$$
\text { Fuelstk }_{\mathrm{i}, \mathrm{f}, \mathrm{t}}=\mathrm{BHM}_{\mathrm{i}, \mathrm{i}} \cdot \text { Fuelstk }_{\mathrm{i}, \mathrm{f}, \mathrm{t}}
$$

where Fuelstk $\mathrm{i}_{\mathrm{i}, \mathrm{f}}=$ the stock of total fuel consumption for fuel $f$ in end-use $i$ from Equation (2.11)

$$
\begin{aligned}
\mathrm{BHM}_{\mathrm{i}} & =\text { the behavioral multiplier for end-use } i \\
\mathrm{t} & =\text { the time index. }
\end{aligned}
$$

In the model, the behavioral multipliers are determined by the ratio of current fuel bills, to historical fuel bills, subject to a delay term. The resulting short-term elasticities, which can be derived from the behavioral multiplier values, are generally from $10 \%$ to $15 \%$. The effect of these multipliers will also be explored empirically in the next chapter. 


\subsection{TREATMENT OF COGENERATION IN THE MODEL}

Within Fossil2's industrial sector, cogeneration is treated as a separate technology option that competes with conventional steam boilers in the skintket for new investments in industrial steam stock. Cogeneration boilers in the model have ihe same fuel options as the conventional boilers and also have their own set of conservation supply curves. In the market share competition, the value of electricity generated is deducted as a credit from the energy service cost computation for the cogeneration technologies. Therefore, when the industrial sector faces a higher electricity price, investments in cogeneration become more economically attractive.

In the Fossil2 structure, the model makes a distinction between "cogeneration" in the industrial sector and non-utility generators or independent power producers (IPPs). In the model, cogeneration is assumed to generate electricity that is consumed entirely within the industrial sector. The electricity produced by the cogenerating boilers is seen as a reduction in the industrial sector's demand for purchased electricity, and the model's reported value of electricity consumed by the industrial sector is the amount generated outside the sector and purchased. ${ }^{(a)}$ Fossil2 considers IPPs separately in its electricity sector.

\subsection{RENEWABLES}

In addition to the biomass fuels, which compete with the fossil fuels for market share in industrial steam and cogeneration, there are several sources of renewable energy that are specified exogenously in Fossil2. For example, consumption in the industrial sector of pulp and paper waste, urban solid waste, and geothermal energy is included in the model. An exogenous forecast of hydroelectricity generated within the industrial sector for its own consumption is also incorporated as a reduction in the industrial sector demand for purchased electricity.

\subsection{FEEDSTOCKS}

Fossil2 cannot model the petrochemicals or other energy feedstocks industries in detail. Therefore, fuel consumed as feedstocks must be set exogenously so that it can be included in the

(a) Fossil2 also includes electricity self-generating technologies for industrial machine drive services, but the amount is quite small. 
industrial energy projections and system-wide energy balances. Feedstock assumptions for the NES analysis were taken from Assumptions for the Annual Energy Outlook 1990 (EIA 1990) and are shown in Table 2.3.

TABLE 2.3. Industrial Feedstocks Assumptions ${ }^{(a)}$

\begin{tabular}{|c|c|c|c|c|c|}
\hline Year & $\begin{array}{l}\text { Asphalt } \\
\text { (mbd) }\end{array}$ & $\begin{array}{l}\text { Other Liquids } \\
\text { (mbd) }\end{array}$ & $\begin{array}{c}\text { Liquids } \\
\text { Total } \\
\end{array}$ & $\begin{array}{l}\text { Gases } \\
\text { (TCF) }\end{array}$ & $\begin{array}{l}\text { Met. Coal } \\
\text { (MST) }\end{array}$ \\
\hline 1990 & 0.5 & 1.9 & 2.4 & 1.1 & 46 \\
\hline 2000 & 0.5 & 2.0 & 2.6 & 1.1 & 45 \\
\hline 2010 & 0.6 & 2.2 & 2.8 & 1.1 & 40 \\
\hline 2020 & 0.6 & 2.4 & 3.0 & 1.1 & 35 \\
\hline 2030 & 0.6 & 2.6 & 3.2 & 1.0 & 25 \\
\hline
\end{tabular}

(a) mbd = million barrels/day; TCF = trillion cubic feet; MST = million short tons.

Source: DOE $1991 \mathrm{~b}$. 


\subsection{RESULTS AND ANALYSIS OF SIMULATION RUNS}

In this chapter, we present the results of simulation exercises performed using the Fossil2 model. Our purpose is to demonstrate the model's behavior in different policy scenarios and under different values of key model parameters. The combination of the model description in Chapter 2 ard the case studies presented in this chapter will offer industrial program managers and interested industrial energy analysts a better understanding of the potential applications as well as the limitations and shortcomings of the Fossill model's industrial sector module. This knowledge should belp CE and OIT to participate in and contribute to DOE policy studies in which the Fossil2 model is employed.

All of the cases discussed in this chapter were run with the Fossil2 model at PNL using the NES Actions Scenario of 1991 as the point of departure. The cases examined here are purely illustrative. That is, no policy recommendations are implied, and our choice of the NES Actions Scenario as our rcference case reflects the fact that its assumptions and results are familiar to a wide audience of DOE energy analysts. Detailed results of the Fossil2 cases run for this study are included in the appendix. The projected industrial energy consumption results for the NES Actions Case are shown in Figure 3.1. A complete description of the NES assumptions and projected results are provided in DOE (1991b).

\subsection{INVESTMENTS IN ENERGY EFEICIENCY AND FUEL MARKET SHARES}

In Chapter 2, we discussed the key factors for determining the investments in energy efficiency in the model. Two parameters critical to these investment decisions are fuel prices and consumer discount rates. In this section, we will test the respnnsiveness of these investments over a range of fuel prices and discount rates. Our measure of responsiveness will be the amount of energy consumed over time in the industrial sector. As discussed in Chapter 2, earlicr studies (DOE 1991a) bave demonstrated that external policies will have a negligible effect on the energy service demands in Fossil2. Therefore, we can attribute the difference in total energy consumption between two cases to investme nts in energy efficiency.(a)

(a) One complication is the effect of the short-term behavioral multiplier on fuel consumption; we also present the results of testing this effect in this chapter. 


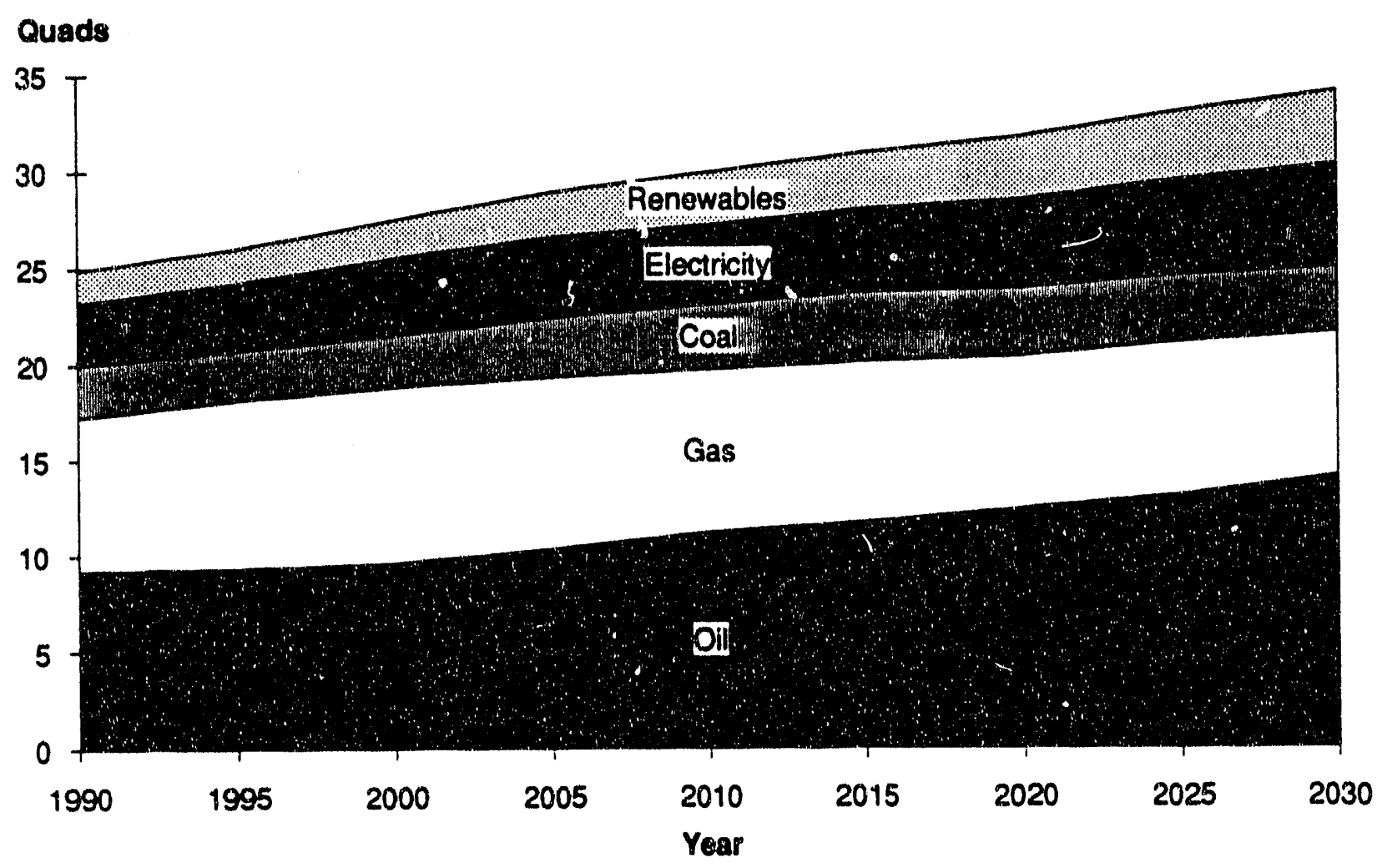

FIGURE 3.1. NES Actions Case: Total Industrial Sector

Energy Consumption, by Fuel

\subsubsection{Response to Fuel Prices}

A carbon tax as a policy affecting end-use fuel prices has been studied extensively (DOE 1991a). A carbon tax can be considered a surrogate for changes in fuel price for our purposes here. The price increase due to a carbon tax is directly proportional to the carbon content of the fuel. For coal, oil, and gas the carbon contents used in the Fossil2 model are 25.45 Teragrams carbon ( $\mathrm{TgC}$ ) per quad, ${ }^{(a)} 20.98 \mathrm{TgC}$ per quad, and $14.55 \mathrm{TgC}$ per guad, respectively (AES 1991). Therefore, a tax of $\$ 100$ per metric tonne of carbon $(\mathrm{mtC})$ would add approximateiy $\$ 2.55$ per million Btu to the price of coal, $\$ 2.10$ per million Btu to the price of oil, and $\$ 1.46$ per million Btu to the price of natural gas. In our analysis, renewable fuels are not penalized under

(a) In Fossil2, energy is measured in English units (quads, or quadrillion Btu, where 1 quad is equivalent to approximately 1.05 exajoules), while carbon emissions are measured in metric units. 
the carbon tax. In the carbon tax cases studied here, the taxes were applied to the entire energy system. As a result, the electricity price faced by the industrial sector reflects the carbon tax paid by the electric utilities and its effect on the fuel mix in the utility sector.

Carbon taxes (or any energy taxes) affect both the amount of energy consumed and the market shares of competing fuels. A series of carbon taxes from \$0/mtC (NES Actions Case) to $\$ 750 / \mathrm{mtC}^{(a)}$ were run using the Fossil2 model. Figure 3.2 shows industrial energy consumption values from Fossil2 for 1990 to 2030 under a $\$ 250 / \mathrm{mtC}$ carbon tax. Compare this figure with the NES Actions Case results in Figure 3.1. As expected, total energy consumption is decreased

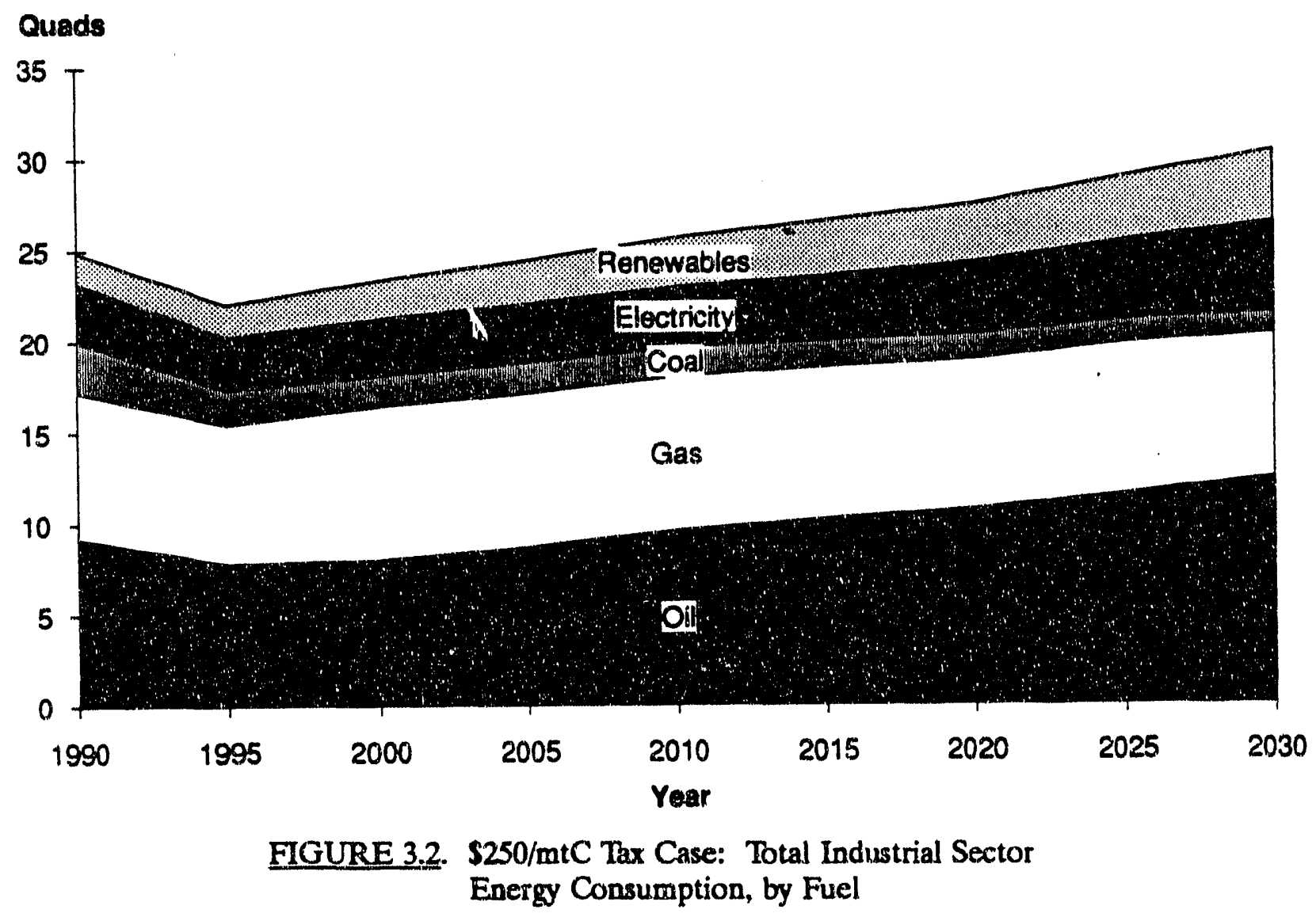

(a) These levels of carbon taxes are studied here for illustrative purposes only. Study of the structural changes to the energy economy that might be caused by extremely high carbon taxes is beyond the scope of the Fossil2 model. 
under the carbon tax. The difference is sharp at first, with the carbon tax reducing consumption by $15 \%$ relative to the NES Case in the year 2000 , leveling off to a decrease of $11 \%$ by 2030 .

One reason for the leveling off towards the end of the time horizon is the effect that the carbon tax has on investments in cogeneration. Because the carbon tax increases the price of electricity, cogeneration receives a favorable push in the market for investments in new steam stock. Of course, this incentive is considered jointly in the model with the carbon tax that must be paid for burning fossil fuels in a cogeneration facility, but the net effect in some situations will be an increase in cogeneration. We see that in the Fossil2 carbon tax cases here. The net effect of an increase in cogeneration is that, because some quantity of electricity generation is shifted from the electric utility sector to the industrial sector, the corresponding energy transformation losses are also shifted from utilities to the industrial sector. Thus, the reduction (from a carbon tax) in energy consumption attributed to the industrial sector will be offset to some extent by an increase in cogeneration, although the total consumption of the entire energy system will decrease accordingly. Cogeneration is a prime example of a situation in which an integrating model of the energy system will capture an effect more completely than a stand-alone industrial sector model would be capable of doing.

Among the individual fuels, coal consumption is affected most by the tax. Its use under the carbon tax is about 35\% of its projected use under the NES Actions. Although the price of gas is penalized, gas consumption is slightly higher under the carbon tax, as its relative price becomes more competitive. The consumption of electricity and oil are reduced in the carbon tax case by $8 \%$ and $14 \%$, respectively, relative to the NES Case in 2030. Renewables consumption appears to have reached a maximum constraint in the model at just under 4.0 quad. Although its relative price is favorably affected by the carbon tax, renewables consumption does not increase, according to the model. Although there is no constraint in the model on the consumption of renewables per se, the model's market share computations do specify portions of the market in which certain fuels are not included in the competition for new investments. Neither the values nor the basis 
for these market share groupings and constraints are well-documented, ${ }^{(a)}$ and, as discussed in Chapter 4, may be an issue for further study.

Figure 3.3 shows industrial energy consumption in the year 2030 for all the carbon tax cases studied here. In addition to the relationship between carbon tax rates and industrial energy consumption, Figures 3.2 and 3.3 show how the market shares of fuels within the industrial sector change under a carbon tax. Recall, however, that Fossil2 computes market shares for new investments orily. The carbon tax then affects the market share directly just at the margin. Market shares for capital stock already in place are not affected, and the fuel mix of the entire capital

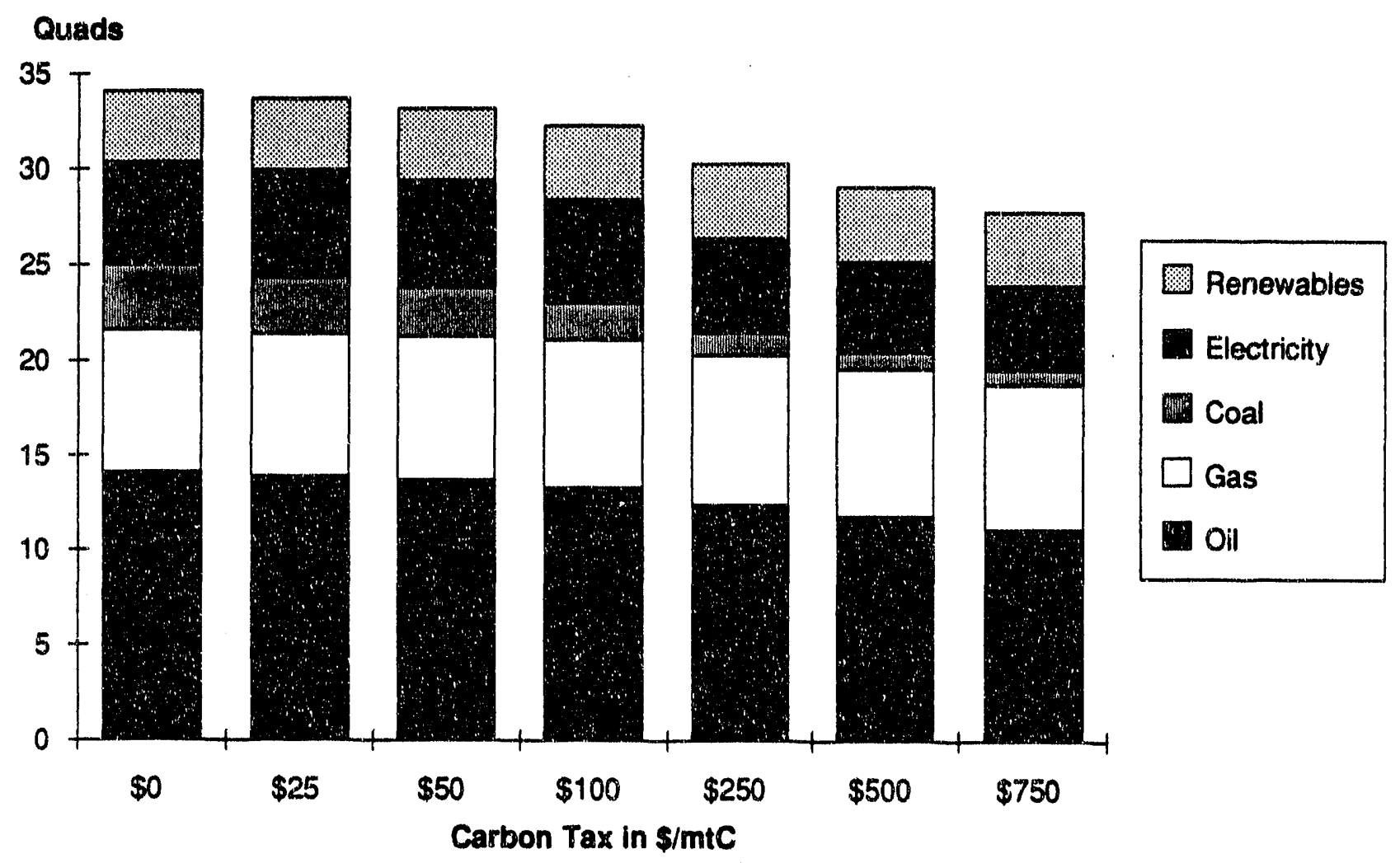

FIGURE 3.3. Total Industrial Sector Energy Consumption in 2030 versus Carbon Tax Rate

(a) The difficulty in specifying explicit market share constraints is an artifact of the modeling approach employed, as well as of the DYNAMO computer language. Actual values for market share constraints in the existing code would have to be derived by exercising the model over a range of relative fuel prices. 
stock takes time to adjust to a carbon tax as old stock retires. Figure 3.3 shows the fuel mix after the carbon taxes have been in place for approximately 40 years. In Figure 3.2 , the adjustment in the fuel mix over time is more clearly portrayed.

From Figure 3.3, we see that the $\$ 750 / \mathrm{mtC}$ tax drives coal virtually out of the fuel mix of the industrial sector. The share of gas, however, is increased by the carbon taxes, from $21 \%$ in the NES Case to $27 \%$ under the $\$ 750 / \mathrm{mtC}$ case. The shares of oil and electricity are relatively unaffected by the tax. As discussed above, renewable energy consumption in Fossil2's industrial sector module appears to have an inherent maximum of about 4 quad. The carbon tar cases put renewables at its maximum in the model, so its share grows only slightly as total sector consumption decreases.

\subsubsection{Response to Discount Rates}

As discussed in Chapter 2, the discount rates for industrial energy consumers are an integral factor in Fossil2's handling of the investment in energy efficiency and, consequently, play a significant role in determining total industrial sector energy consumption. Because of their importance, it is instructive to analyze the effect of a range of rates on Fossil2's energy consumption projections.

Figure 3.4 shows Fossil2 projections of industrial energy consumption, by fuel, for the year 2030, assuming discount rates of 5\%, 10\%, 25\% (NES Action Case), and 33\%. As expected, total energy decreases as the interest rate decreases. With total sector consumption of 31.6 quad at a $5 \%$ discount rate and 35.0 quad at a $33 \%$ discount rate, the range of variation is just under $11 \%$. The contributions to total consumption by each fuel, however, do not change uniformly with the discount rates. For example, the total share of electricity, a relatively capital non-intensive choice, is about $11 \%$ in the $5 \%$ discount rate case but grows to just under $20 \%$ in the $33 \%$ case. On the other hand, the total share of coal changes inversely with the discount rate, with a share of $10 \%$ in the $5 \%$ case and a share of $8 \%$ in the $33 \%$ case.

These cases show that fuel consumption in Fossil2 does not necessarily decrease as discount rates are lowered. At first, this may appear counterintuitive as well as contradictory to the prevailing opinion that one way to decrease energy consumption would be, through some 


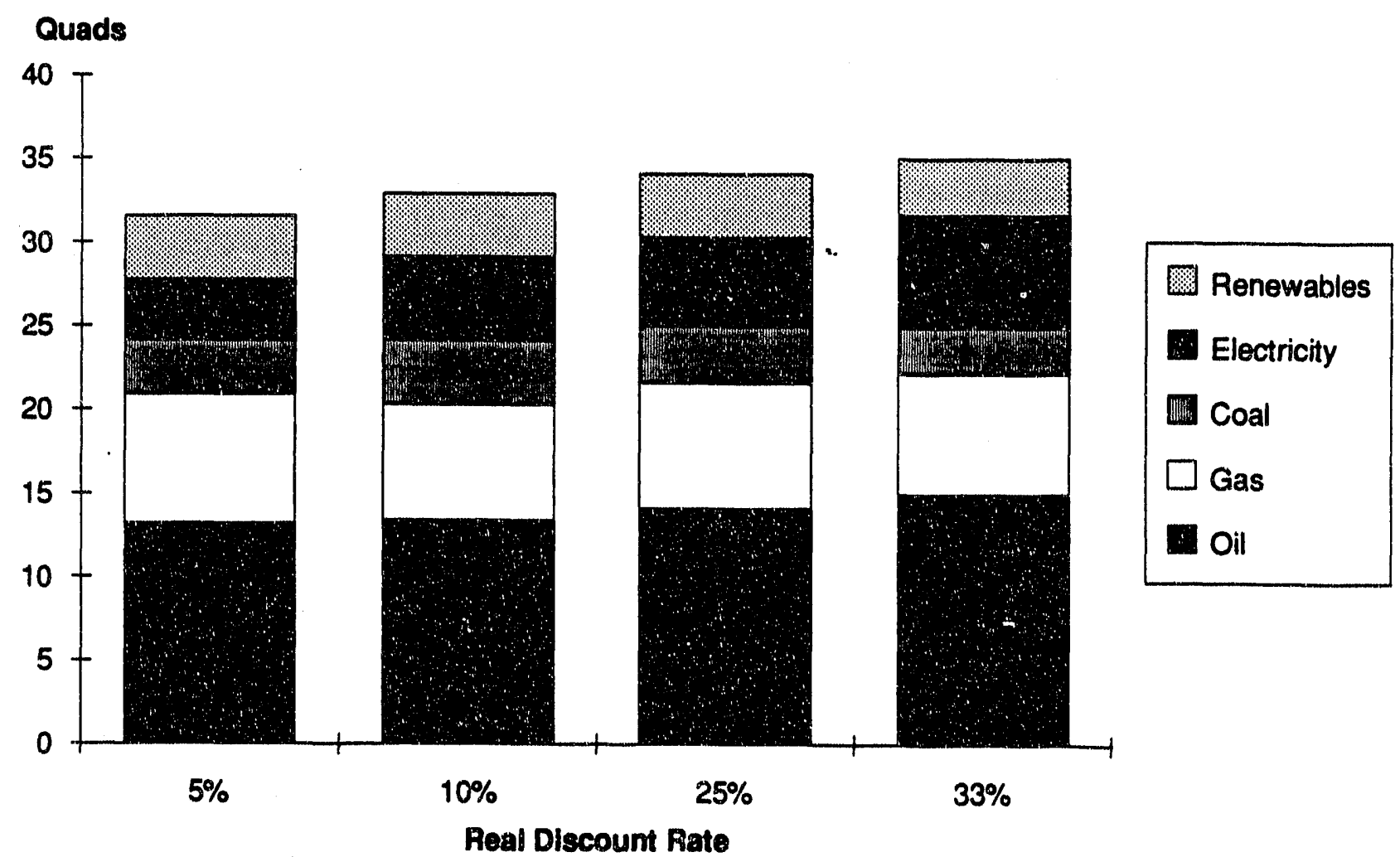

FIGURE 3.4. Total Industrial Sector Energy Consumption in 2030 by Discount Rate

informational or financial assistance program, to effectively lower the hurdle rates consumers typically apply when purchasing energy-consuming equipment. While this is generally true, in some cases, the situation is more complicated.

What a lower discount rate really implies is that consumers will be willing to make higher levels of capital investments in energy equipment in order to take advantage of future fuel cost savings. The discount rate is applied not just to the capital investments in higher levels of energy efficiency, but also to the base cost of capital equipment for each fuel and end-use combination. Capital investment generally implies higher levels of investment in energy efficiency, as exemplified in Fossil2's conservation supply curves; but a lower discount rate also means that investments in a relatively inexpensive but capital-intensive fuel such as coal will become more attractive, with the potential end result that coal consumption increases as the discount rate decreases. This point is emphasized here because it provides an excellent illustration that the Fossil2 model is an 
appropriate tool for capturing complex interactions among competing causal factors. Such interactions might not be immediately obvious to an analyst without the aid of a model. ${ }^{\text {(a) }}$

As in the carbon tax cases, there are also interactive effects as investment in cogeneration capacity transfers some conversion losses from the utility sector to the industrial sector and, thus, masks the impact of energy savings when the industrial sector is studied in isolation. In general, cogeneration is relatively capital-intensive, so lowering the discount rate to $5 \%$ will increase cogeneration investment, while raising it to $33 \%$ will decrease investment. As the output tables in the appendix show, however, lowering the discount rate to $10 \%$ decreases investment in cogeneration relative to the NES Actions Case results. This result indicates that the $10 \%$ discount rate, in conjunction with the relevant capital costs and fuel prices, causes the discounted life-cycle costs of coal and biomass conventional boilers to be less than that of cogenerating boilers. Again, this point is stressed to show how a model like Fossil2 can capture complex interactions among different causal factors.

Figures 3.5a, 3.5b, and 3.6 provide more results from varying the Fossil2 industrial sector discount rates. Figures 3.5a and 3.5b show the time-trajectory of consumption, by fuel, for the 5\% and $33 \%$ cases, respectively. Figure 3.6 offers a time comparison of total industrial sector energy consumption projections over the range of discount rates studied here.

\subsection{RETIREMENT RATES}

One of the limitations of the Fossil 2 model is that, because retirement rates are exogenous constants, the model does not allow for early retirement of capital stock as it becomes uneconomic relative to other options. In the end-use sectors, the retirement rate limits the introduction of energy-efficient stock into industrial operations. To explore the sensitivity of the model results to changes in the retirement rate of capital stock, we accelerated and decelerated retirement rates by $25 \%$ relative to the base rates used for the NES. [See Equation (2.8), Chapter 2.] One would have expected overall energy consumption to increase when the penetration rate of efficient

(a) This result has some interesting implications for carbon emissions studies, as there may be a perverse region where lowering discount rates raises carbon emissions by stimulating a switch to coal from oil and gas in the sectors in which coal is available. 


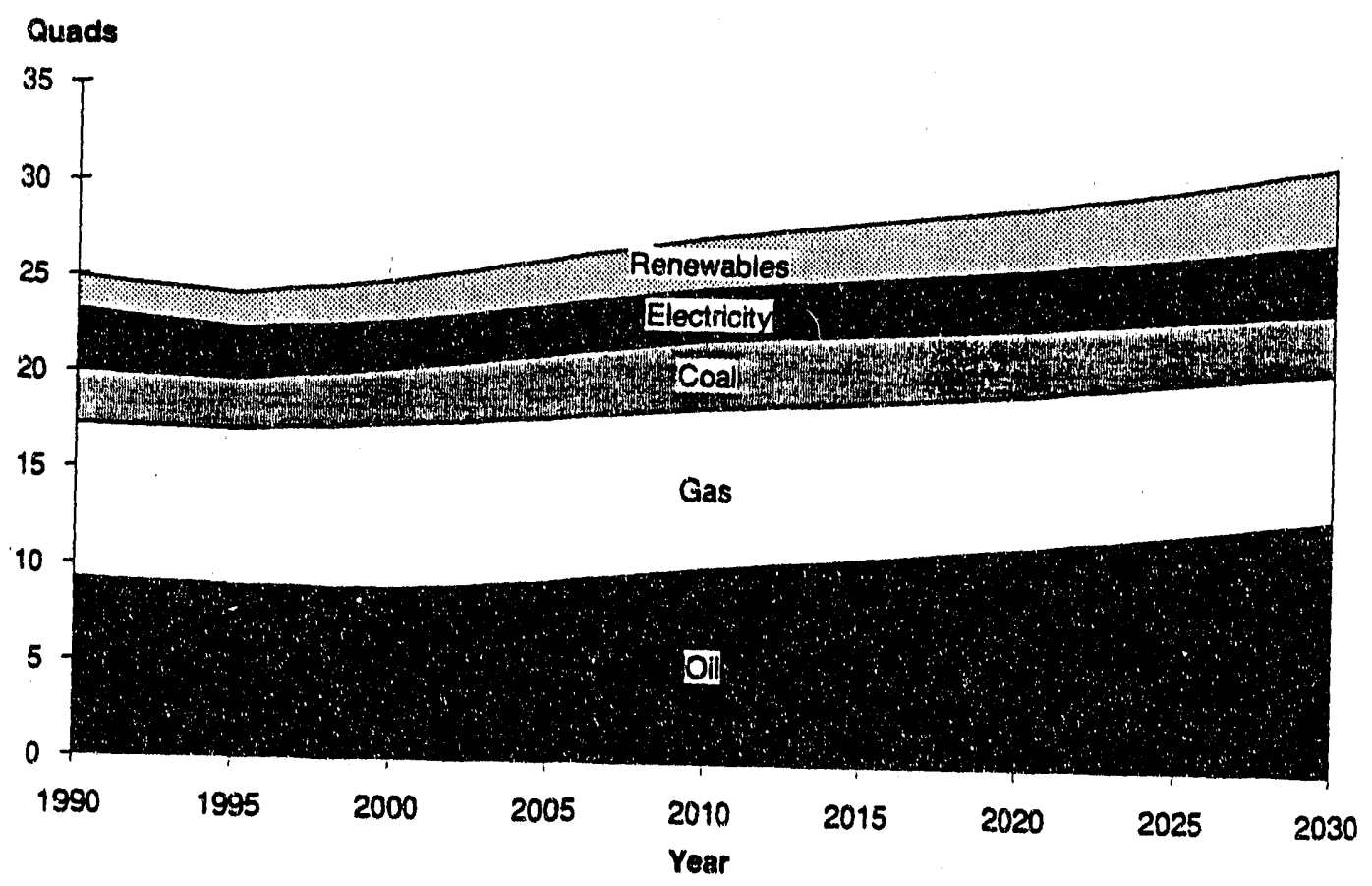

FIGURE 3.5a. 5\% Discount Rate Case: Industrial Sector Energy
Consumption, by Fuel

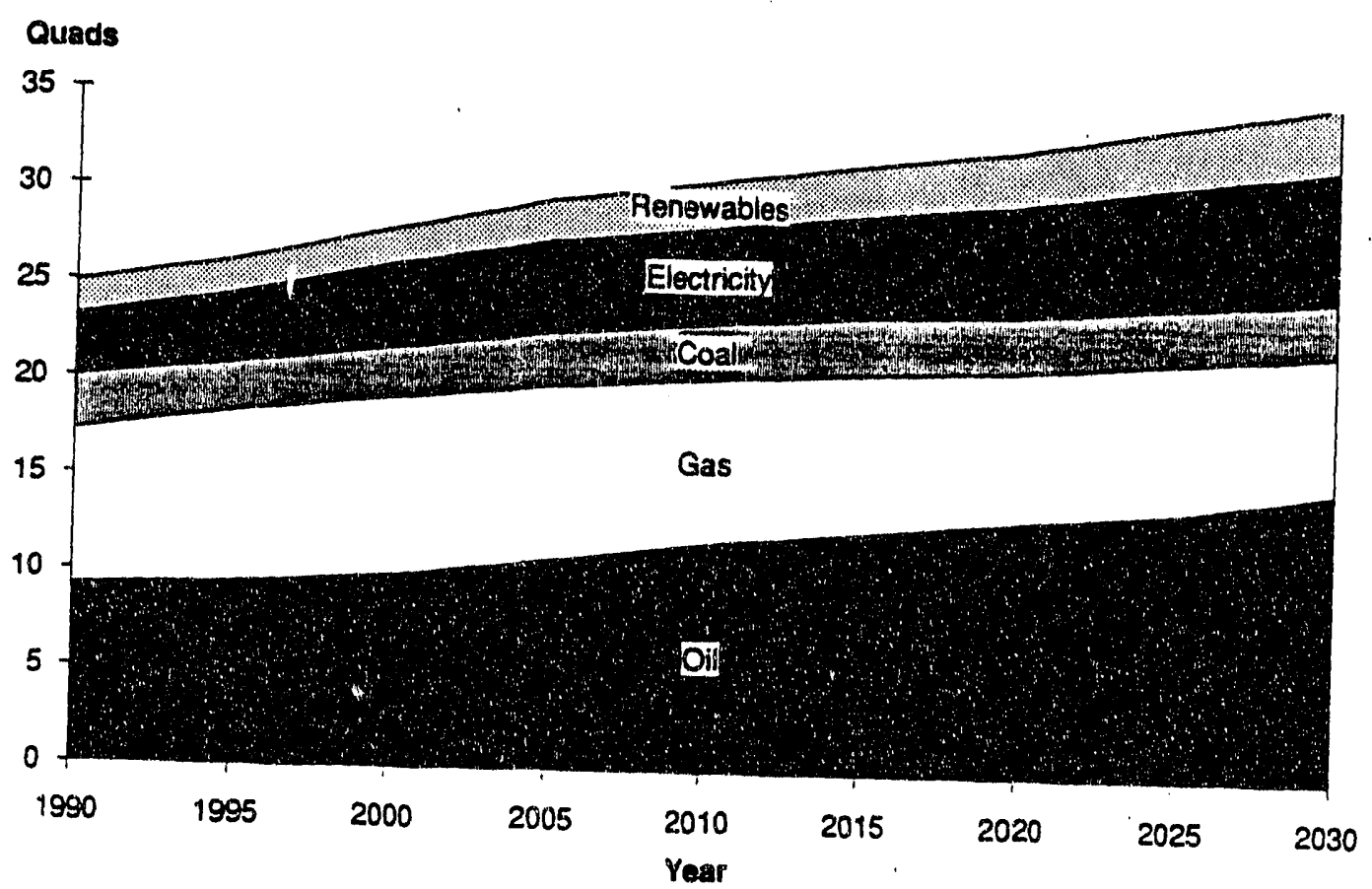

FIGURE 3.5b. 33\% Discount Rate Case: Industrial Sector Energy Consumption, by Fuel 


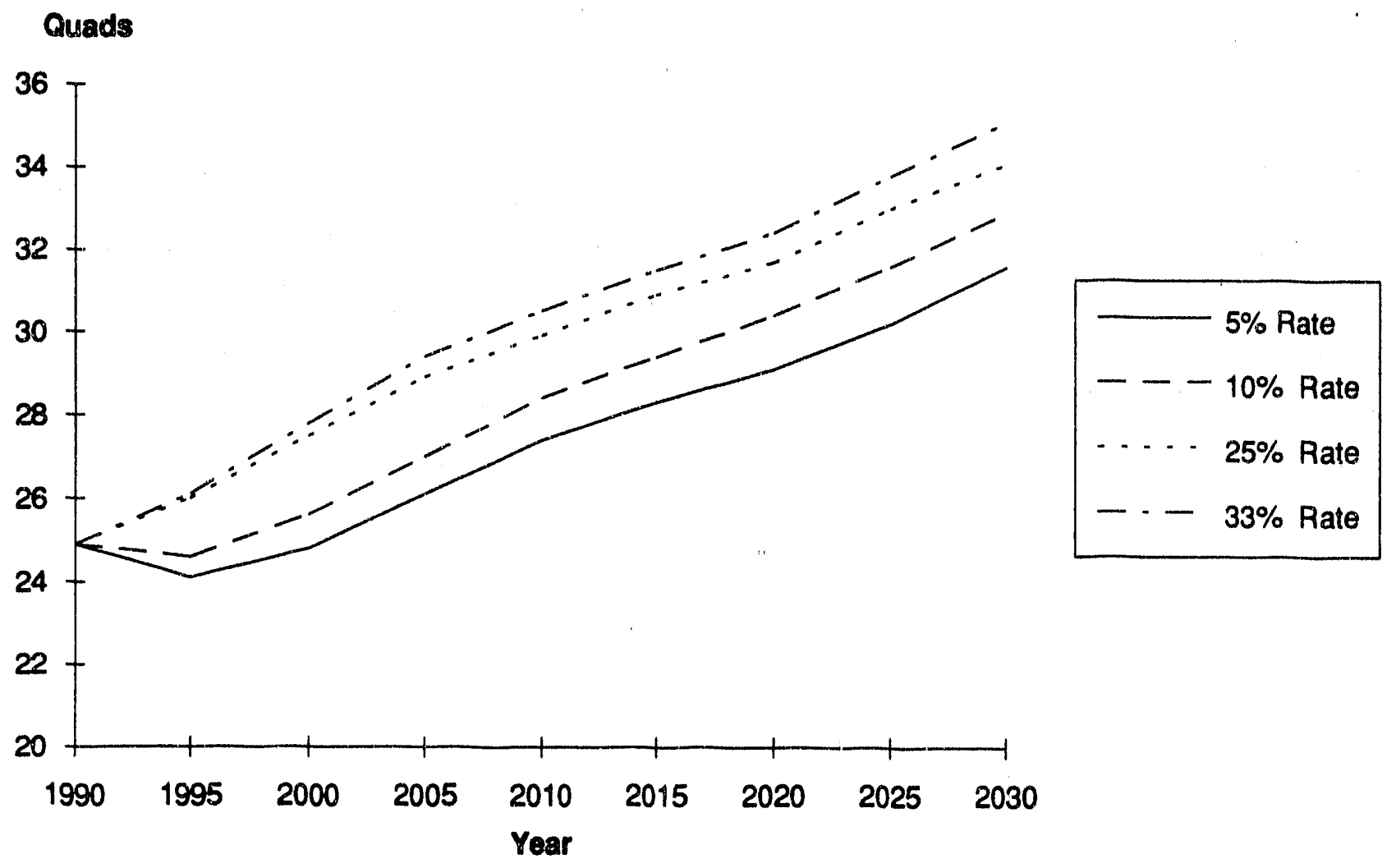

FIGURE 3.6. Total Industrial Energy Consumption in the Discount Rate Cases

technologies decreased, and vice versa. However, overall energy consumption increased slightly (by about $1 \%$ ) for both decelerated and accelerated retirement rates relative to the NES Actions Case--in fact, as illustrated in Figure 3.7, the results were about the same for the two cases. (See Sections 3.3 and 3.4 for discussions of the No Behavioral Multiplier Case and the No Retrofit Case, respectively.) For differences, we must look to the projected fuel mixes.

\subsubsection{Deceleration}

The most significant effect under decelerated retirement rates was a decrease in the amount of cogeneration used relative to the NES Actions Case. As shown in Figure 3.8, cogeneration energy use decreased by 0.5 quad per year, or about $9.5 \%$, by 2030 . Figure 3.9 , which illustrates the total industrial energy use by fuel in 2030 , indicates that the market shares for the different fuels changed only slightly relative to the NES Actions Case. As would have been expected under the slower introduction of new technology that accompanies decreased retirement rates, 


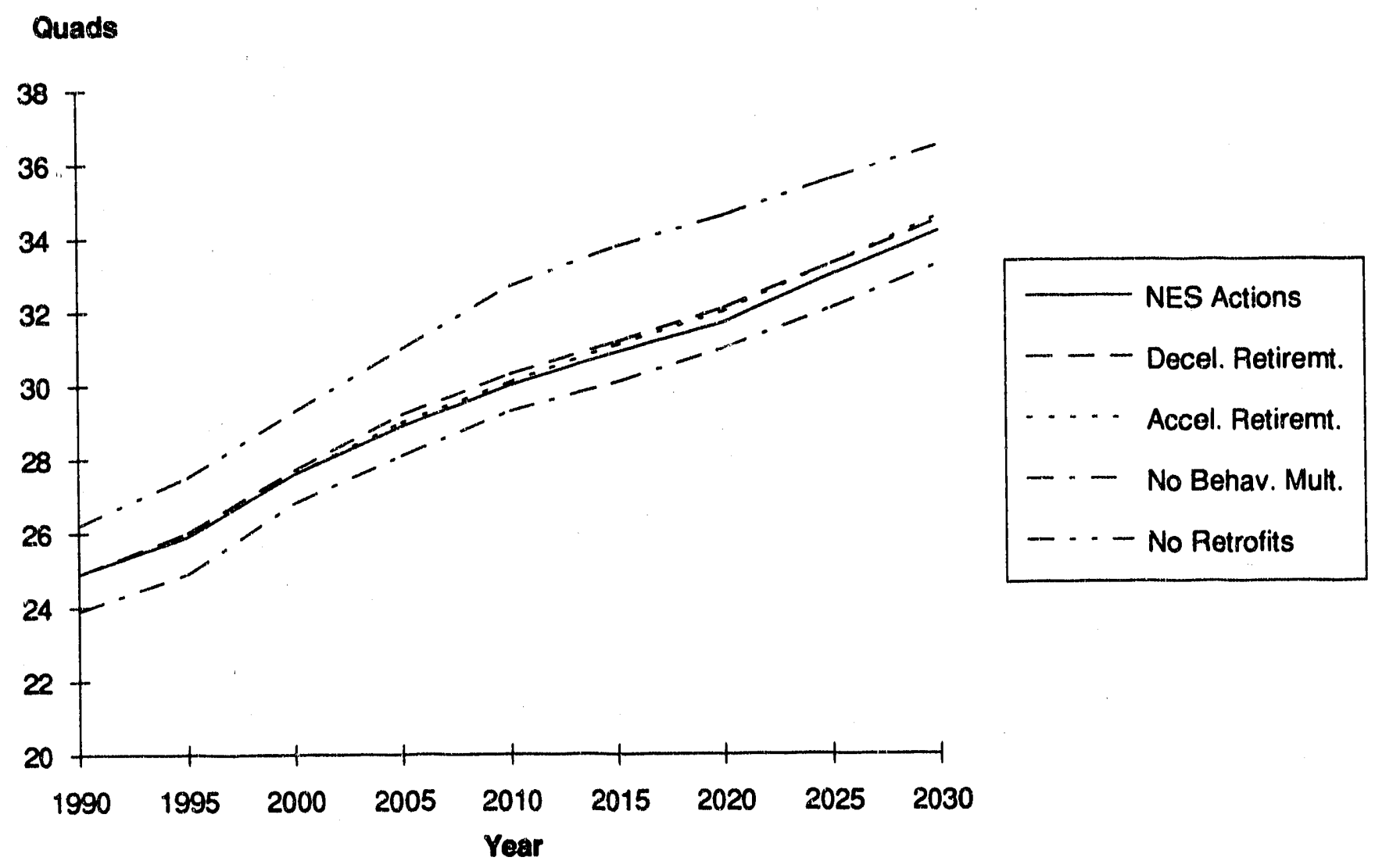

FIGURE 3.7. Total Industrial Energy Use for Various Cases

renewables decreased market share, while electricity increased (probably due to price effects). An increase in electricity use and a concomitant decrease in cogeneration means that additional transmission losses are introduced, resulting in an increase in overall energy use; however, this effect would be captured in the utility module rather than in the end-use modules.

\subsubsection{Acceleration}

The most significant effect under accelerated retirement rates was an increase in the amount of cogeneration used. As shown in Figure 3.8, cogeneration energy use increased by 0.4 quad per year, or about $7.5 \%$, relative to the NES Actions Case in 2030. The fact that more energy is used in industry under this scenario is an artifact of the model's accounting structure--primary energy use for electricity production is accounted for in the utility module, while primary energy use for cogeneration is accounted for in the industrial module. As shown in Figure 3.9, oil use was 


\section{Quads}

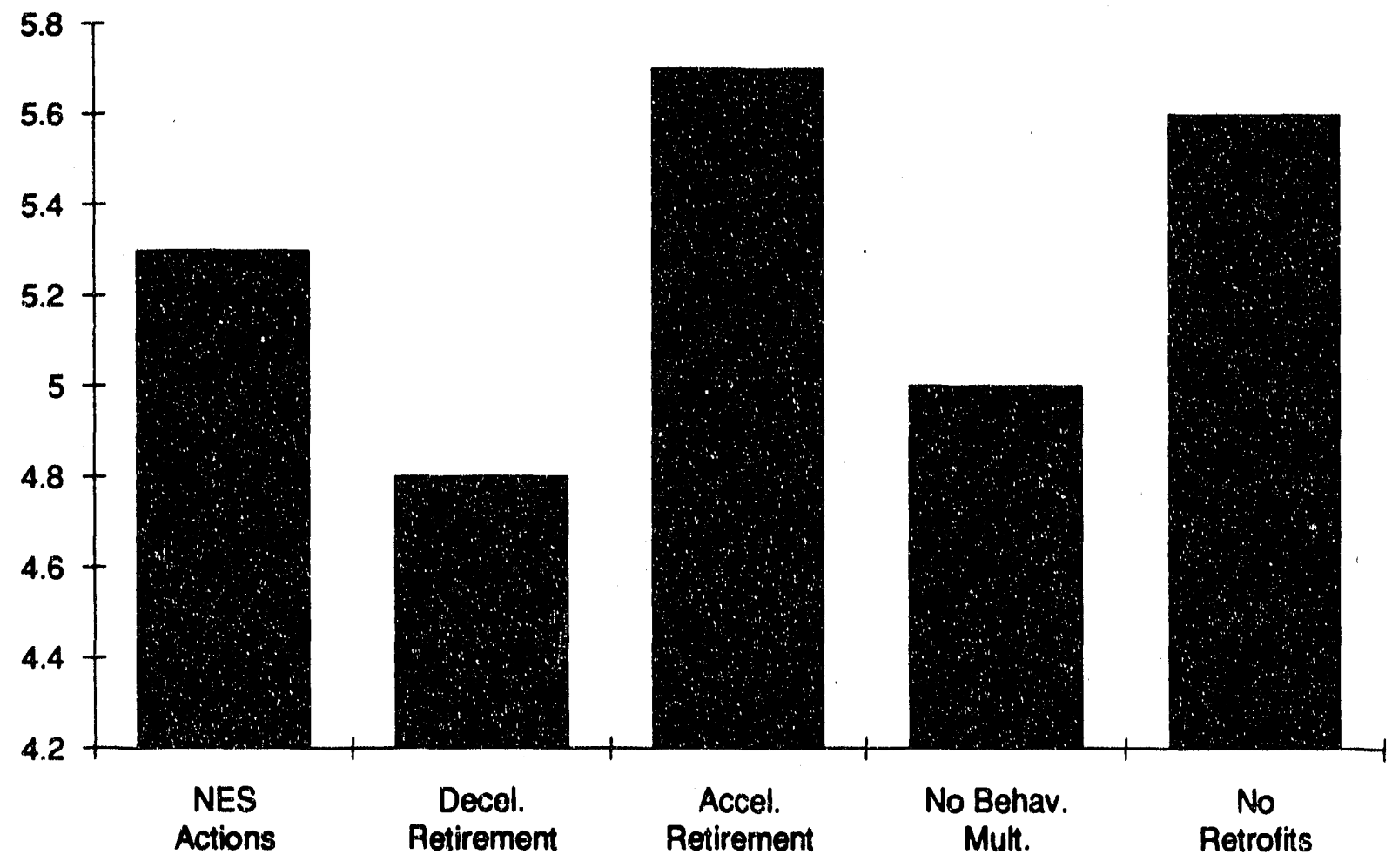

FIGURE 3.8. Total Cogeneration Energy Use in 2030 for Various Cases

roughly the same as in the NES Actions Case by 2030. Less gas was used in absolute terms; the market share also decreased. Coal use was about the same. As expected under the increased rate of new technology introduction that accompanies increased retirement rates, renewables increased market share; electricity use also increased, (again) probably due to price effects.

\subsection{NO BEHAVIORAL MULTIPLIER CASE}

The behavioral multiplier accounts for short-term energy management activities in response to fuel price changes. Its effect on fuel use is effectively removed by setting the energy management delay term (see Section 2.5) to virtual infinity (in this case, 100,000). As shown in Figure 3.7, when the behavioral multiplier is effectively "turned off," overall energy use decreases, a result that suggests that some degree of "take-back" occurs in the NES Actions Case. That is, in the NES Actions Case, the short-term energy management activities initially reduce the demand for energy. As prices fall in response to the drop in demand, energy use increases. This rebound 


\section{Quads}

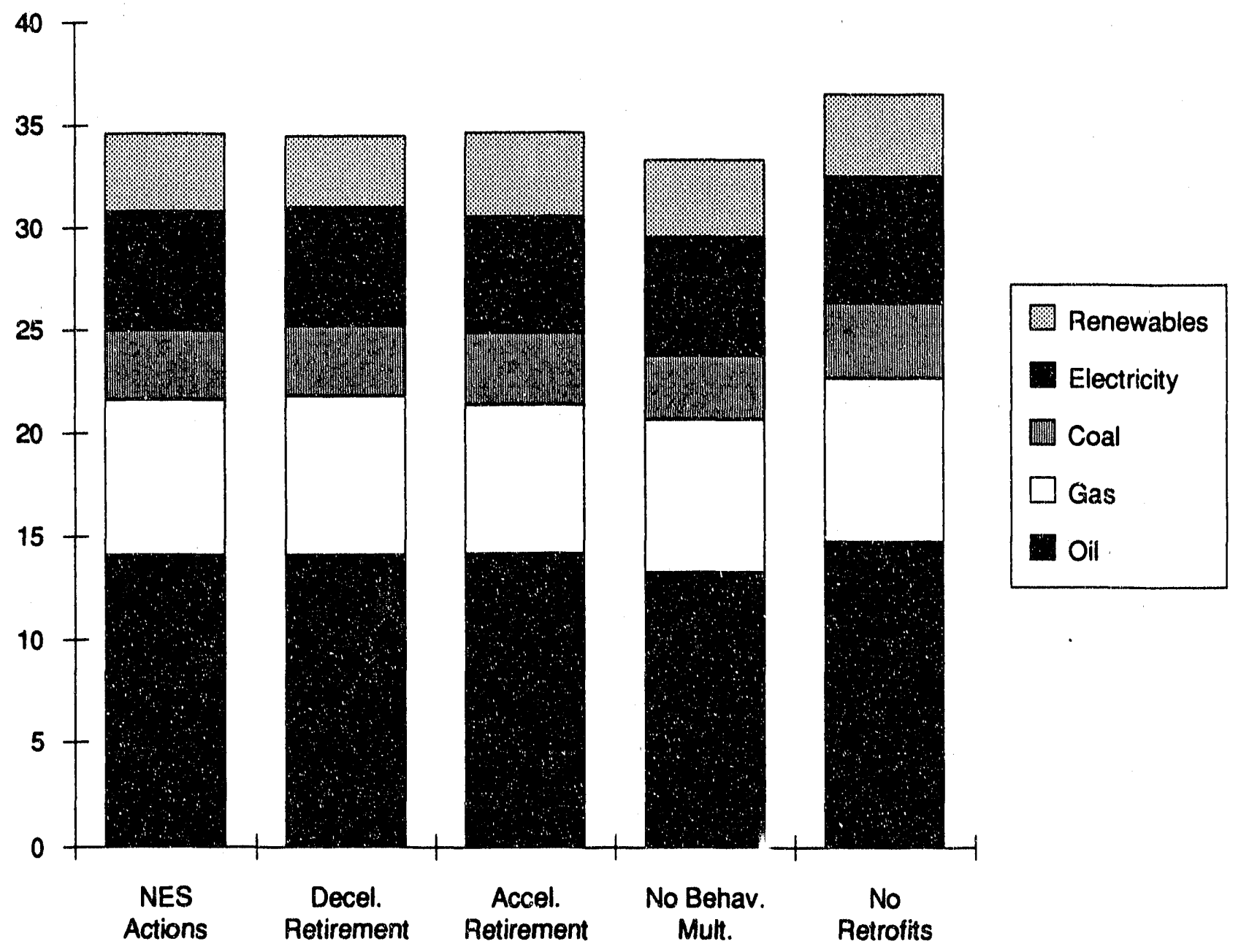

FIGURE 3.9. Total Industrial Energy Use for Various Cases

in energy use is known as "taking back" the energy savings. That turning off the behavioral multiplier in Fossil2 causes energy use to decrease indicates that this take-back behavior was occurring (being modeled) in the NES Actions Case. This is reflected in the model by setting the behavioral multiplier to a value greater than one.

Turning off the behavioral multiplier also causes cogeneration use to decrease slightly (see Figure 3.8). As shown in Figure 3.9, oil use decreases in market share, while gas use remains roughly the same. Coal also decreases in market share. Electricity increases most dramatically in market share, while renewables increases slightly. 


\subsection{NO RETROFIT CASE}

As described in Chapter 2, another of the factors incorporated into Fossil2's energy consumption projections is the reduction in demand due to retrofits of existing equipment. The reductive effect of retrofits on energy consumption is removed by setting the delay terms (see Equation 2.11, Chapter 2) to virtual infinity (in this case, 100,000). (a) As a result, overall energy use is increased by a little under 7\% (see Figure 3.7). Oil use decreases in market share after 2010. The gas market share increases slightly, then decreases slightly after 2010 . The coal market share is slightly lower. The electricity market share decreases significantly after 2005 , while the renewables market share remains approximately the same. Under this case the amount of cogeneration used increased, as illustrated in Figure 3.8.

(a) Recall that the delay terms influence the rate at which retrofits move the efficiency of the existing stock toward a target efficiency. 


\subsection{SUGGFSTIONS FOR USE AND FURTHER DEVELOPMENT}

In this chapter we consider pocsible improvements and enhancements to both the Fossil2 industrial sector module and the manner in which it is used in policy analysis. Some actions would be relatively simple; others would require more significant efforts. We begin with the simpler actions, which could be undertaken in the short term. The immediate goal of these actions would be to improve the model's handling of the industrial sector for future NES analyses. Because DOE may wish to continue using Fossil2 as a policy analysis tool for some time, we conclude by offering some options for more substantive efforts to improve the model's industrial sector. ${ }^{(a)}$

A number of Fossil2 development efforts are planned or under way, some of which affect the industrial module. These activities, and their sponsors, are listed for reference in Table 4.1.

\subsection{STRATEGIES FOR IMPROVEMENTS IN MODEL USE}

Near-term improvement strategies are those that can be implemented immediately at little cost and that will improve the use of the model results. These strategies focus primarily on reporting the assumptions, the parameter values, and the results of the analysis. Off-line calculations or model runs used to derive model inputs to Fossil2 should be clearly described. Reporting such factors allows the analyst to provide decision-makers with better interpretations of model runs. Some of the assumptions and parameter values that should be reported are discussed below.

\subsubsection{Product-Process Change Multipliers}

The PPCM structure limits the Fossil2 industrial sector to performing analysis of economic behavior around a predeternined industrial product and process mix scenario. As a consequence, Fossil'2 is not able to capture the effects of energy policies on the product and process mix. This need not be considered a shortcoming of the model. Fossil2 is an aggregate integrating model of

(a) These development efforts are discussed under the assumption that Fossil2's current " constraint on computer memory is a temporary problem that will be overcome in the very near future. 
TABLE 4.1. Summary of Current Fossil2 Development Activities and Sponsors

\section{INPUT/OUTPU'T ROUTINES}

Input User Interface (EP). ${ }^{(a)}$ Develop a spreadsheet summarizing basic assumptions to load data into model input tiles and :o document NES base case variables.

Output User Interface (EP). Make model output files compatible with the new output spreadsheets.

\section{MACROECONOMIC SECTOR}

Calculation of Welfare losses (EP/OEA). (b) Develop a method for calculating changes in consumer and producer surplus.

\section{SUPPL $: A C T O R S$}

Electricity Sector..-Capacity Expansion/Dispatching (CE/OUT/OPA).(c) Develop new electric utility capacity and dispatching rules to 1) compete specific technologies for specific parts of the load; 2) allow for substantial changes in the load duration curve; 3 ) better represent intermediate and peaking capacity construction decisions.

Electricity Sector-IPP Structure Improvements (CE/OUT/OPA). Examine major decision factors in the IPP sector to determine the adequacy of the IPP representation; complete validation test of IPP structure relative to the recent market trends (1980-1990).

\section{END-USE SECTORS}

Transportation Sector--Basic Redesign (EP). Develop and implement a redesigned transportation sector, including final design, data development, coding, testing, and documentation.

Buildings and Industrial Sectors--Demand-Side Management Investments (CE/OPA). Investigate approaches to a model structure to directly compete demand (i.e., demand side management-DSM) and supply-side utility investments.

Bulldings Sector-.New Residentlal and Commerclal End Uses (CE/OPA). Increase the number of end uses in Fossil2 residential and conmercial buildings sectors to erable more precise calibration with other buildings models and to enhance Fossil2 policy analysic capabilities.

Industrial Sector-add Motors and Lighting End-uses (CE/OPA). Subdivide the current single industrial electricity end-use, machine drive/electrolytic, into three end-uses: motors, lighting and other electric.

(a) DOE's Office of Domestic and International Energy Policy (EP).

(b) DOE-EP's Office of Economic Analysis (OEA).

(c) DOE-CE's Office of Utility Technoiogies (OUT) and Office of Planning and Assessment (OPA). 
the U.S. energy economy, and the industrial sector module is just one of several component pieces. However, the importance of the PPCM parameters to the model cannot be overstated.

Because of their importance, the procedure for deriving the time-dependent PPCMs, and the PPCM values, should be reported along with the results of the analysis. Spreadsheets of data that provide input to PPCM derivations-such as economic forecasts by SIC code--should be provided. Although reporting such values or derivations leaves them open to challenge by other parties, this openness will increase the credibility of the analysis.

Another valuable change to the model would be additional "policy handles" related to the PPCMs. These handles could be provided via off-line analysis tools used to derive the PPCMs. For example, an off-line spreadsheet processor could used to make parametric changes to product mix and industrial production changes that are then used to modify the PPCMs for input to the model.

Although it is not related to Fossil2 use or modification per se, the importance of research into structural change in industry must be stressed in any discussion of the PPCMs. The effects of basic process choices and changes can have substantial effects on manufacturing energy use, although the changes are rarely made in response to energy price (Ross and Hwang 1992). Research into the factors that affect process changes and into the causes and effects of other industrial structural changes, such as movements toward the import of intermediate goods, is needed to ensure that when we forecast industrial energy use, we are considering the most important issues.

\subsubsection{Other Parameters}

Assumptions embedded in the model, such as the values of behavioral multipliers and capital retirement rates, can also be reported to provide a greater level of insight into the workings of the model in a particular analysis. The embedded market share constraints on fuel use, e.g., those that reflect regional limitations on renewable fuels and the inability to use coal in some applications, can and should also be reported. These parameters are critical to the model's computation of fuel shares; they should be documented and studied further to gain additional insight into the values that should be assigned to these constraints. Documenting and researching these parameters will allow analysts and decision-makers to consider whether the model appropriately reflects 
new policies, such as Clean Air Act regulations, or whether new research findings ought to be considered in developing the constraints for a particular analysis.

\subsubsection{Translation of Policies into Model Inputs or Parameter Changes}

For a given analysis, presumably some potential policy action is being studied. The translation of such policy actions into changes in model inputs or parameters should be made clear. Without such a description, the analyst is at a disadvantage in trying to interpret whether the policy was handled appropriately and in presenting results to decision-makers.

Modeling the effects of accelerated research and development is of particular interest to CE program managers and policy-makers. Different research and development investment policies are perhaps modeled best using a "scenario analysis" approach. That is, a different conservation supply curve for each investment scenario is constructed outside the model, and Fossil2 can then be used to test the impact of the inferred technological improvements within its industrial sector framework.

\subsection{STRATEGIES FOR MORE SUBSTANTIVE CHANGES TO THE MODEL}

In this section, we discuss strategies for changing the industrial module that would require coding changes but that do not involve fundamental changes to how the industrial sector is represented.

\subsubsection{Reporting the Efficiencies of the Capital Stock}

For a scenario run, the Fossil2 output relevant to the industrial sector includes sector-specific fuel prices and fuel consumption by end-use. One of the major obstacles confronting the analyst who interprets the scenario is that he or she is provided fuel consumption results only. The analyst does not bave the information required, for example, to compare two scenarios with different consumption projections and determine why the results differ. In this situation, the analyst can only make an educated guess about how much of the difference is due to changes in service demand, in fuel market shares, in energy efficiency, or in some other factor.

To remedy this problem, Fossil2 could report the energy efficiencies of the capital stock along with the fuel consumption results for each scenario. With this additional information, an industrial energy analyst would be able to compare several scenarios and provide much more 
meaningful interpretations to decision-makers. That is, he or she would have sufficient information to identify the causal factors behind Fossil2's fuel consumption results. Besides helping the analyst understand the model projections, this type of information would also provide a logical explanation for the model results and, thus, give the analysis greater credibility.

The first type of efficiency information that could be added to the output reports would be the average efficiency of each end-use and fuel combination over time. This measure would provide the most information about the scenario, since the average efficiency is a function of current and previous investments. In addition to the average efficiencies, it may be useful to provide the marginal efficiencies being invested in at each time period. The marginal efficiencies would offer a snapshot at different points in time of the level of investments in energy efficiency. Marginal efficiencies would show the instantaneous response to a policy change such as a tax or investment credits.

When technology-based conservation supply curves are used, further insight would be provided by mapping the marginal efficiencies with the corresponding technologies from the supply curves. In fact, this mapping could be automated and incorporated into the model output. However, there are some caveats to this approach. First, the mapping would not be possible in situations, such as the NES analysis, when empirical supply curves are used or when research and development is assumed to shift the supply curve uniformly outward. In these situations, the supply curves lose their technological basis. Second, even in scenarios with strictly defined technology-based conservation supply curves, the aggregation of technologies across an end-use would make the point estimates obtained from the technology investment results meaningless. In other words, the Fossil 2 results would suggest that the entire industrial sector was investing in one technology in each fuel and end-use, clearly an unintended implication. The conclusion drawn here is that the best strategy may be to provide the marginal efficiencies along with annotated supply curves which map ranges of efficiencies along with their corresponding types or groups of technologies.

Implementation is not quite as simple as reporting the values of variables already contained in the model. As explained in Chapter 2, Fossil2 does not compute fuel consumption based directly on physical measures of absolute efficiency. Efficiency in the model is measured relative to a baseline efficiency for each end-use and fuel. These baseline efficiericies are implied, but not 
directly stated in terms of physical efficiencies, in the definition of the base service demand for each end-use. Implementation would therefore require some minor recoding of the model and coordination with the conservation supply curve databases.

\subsubsection{Discrete Vintaging of the Capital Stock}

As explained in Chapter 2, each end-use and fuel combination employs a single, continuous variable to represent the quantity of its capital stock. The Fossil2 industrial sector module, therefore, does not distinguish stock by its vintage or age. Because it has no additional information available to it, the model operates as if retiring stock is at the average stock efficiency. Among the implications of this modeling strategy is that the impact of conservation or energy efficiency investments may be systematically understated. That is, in most cases the older stock would be the least efficient stock, and retiring the older stock first would increase the average efficiency of the stock as a whole. However, under the model's current strategy, this effect is lost as the efticiency of the retiring stock, the average efficiency, is a blend of old and new investments.

The most direct way to impose a greater degree of precision on the model's capital stock flow system would be to implement a system of discrete vintages for the capital stock of each fuel and end-use combination. For example, capital stock could be grouped by 5 - or 10 -year blocks. In a discrete vintaging system, the oldest vintage would be the stock at the assumed maximum capital lifetime, and most of the retirements from stock would come from this vintage. Capital stock in the rest of the vintages would age by flowing into progressively older vintages as the model indexes over time during a simulation run. This strategy could conveniently account for early retirement by specifying a fraction (less than one) of stock at each vintage that "survives" to reach the next vintage. Therefore, it would not be necessary to have all retirements come from the oldest vintage.

Implementing the discrete vintaging system would require a significant effort to collect additional historical data for the industrial sector. A fair amount of recoding would also be required to incorporate the new stock retirement system and to classify parameters such as efficiencies and market shares by vintage. ${ }^{(a)}$ The benefits of the discrete vintaging system would include a

(a) Note that the other end-use sectors in Fossil2 also currently use the same continuous variable vintaging system as the industrial sector. 
greater degree of precision in the model's results, as well as enhanced flexibility in the type of conservation policies that can be tested effectively with the model.

\subsection{STRATEGIES FOR SIGNIFICANT CHANGES TO THE MODEL}

In this section, we discuss strategies for changing the industrial sector module that represents significant changes in that how industrial sector is represented in the module.

\subsubsection{Reorganization of Industrial Sector Based on Industries}

As currently configured, energy use in Fossil2's industrial sector module is aggregated into four broad end-use categories: steam, process heat, industrial machine drive/electrolytic processes, and energy feedstocks. Characteristics of the capital stocks, energy efficient technologies available, investment behavior, and fuel consumption are lumped together in these end-use categories. Because the industrial sector is just one of several energy sectors in the Fossil2 model, this degree of aggregation has not been inappropriate for past studies. While it is not our intention to suggest that the Fossil2 industrial sector be developed to the point at which it could function as a detailed, stand-alone industrial model, if DOE continues to use Fossil2 as a major policy analysis tool, some greater level of detail in the industrial sector model may be justified.

An alternative approach to organizing industrial energy use in Fossil2 would be to group energy demand by industries rather than by the aggregate end-use categories. Several configura. tions would be possible. One that comes to mind quickly is to categorize industrial energy use by higher-level (e.g., two-, three-, or four-digit) SIC codes. The advantage of this method would be that the SIC system is a standard and widely recognized formal classification system, which would tend to facilitate data collection for the model as well as interpretation of the results.

A more innovative aggregation scheme would be one that exploits the fact that the OIT is primarily interested in modeling energy consumption in the industrial sector. The SIC system is constructed as an accounting system for contributions, by sector of the economy, to national output and wealth. It is basically indifferent to relative energy consumption. A classification system that emphasizes detail on energy-intensive industries may prove more appropriate for OIT's purposes. This energy-cognizant classification scheme could also be based on SIC codes, though at different levels of aggregation, depending on contribution to industrial energy consumption, and thus claim some of the aforementioned advantages of using the standard SIC system. 
Ross and Hwang (1992) took such an energy-cognizant approach in developing the LongTerm Industrial Energy Forecasting (LIEF) model. Industries were divided into four sectors: 1) slow-growing, non-energy-intensive; 2) fast-growing, energy-intensive; 3) energy-intensive materials-processing with recycling; and 4) energy-intensive materials- processing without recycling.

The reorganization of Fossil2's industrial sector would definitely not be a trivial undertaking. However, most of the existing modeling paradigm would still be valid under the new system. The existing model structure with respect to energy service demands, investments in energy efficiency, fuel market shares, capital stock turnover, etc., would still be appropriate. The only important difference would be that the industrial classes would be used in place of the aggregate end-use categories. Baseline relationships among national income (e.g., GNP), overall industrial production (e.go, the IPI), and energy consumption within the industrial classes would have to be developed to serve the function of the PPCMs the model currently uses. While such a reorganization would not complicate the model conceptually, it would require substantial effort in terms of collecting data and calibrating the model.

One component might not transfer seamlessly from the end-use aggregation to an industrial classification system: the technology-based conservation supply curves. In fact, Fossil2's aggregate industrial end-use categories were devised to take advantage of common applications of energy use and corresponding technology options across all industries. The technology-based conservation supply curve approach may be less appropriate for an industrial classification system. That is, the degree of heterogeneity of energy-consuming technologies within one industry may be higher than it is for technologies within a common application or end-use. If that proved to be the case, then empirically derived conservation supply curves such as those used in the NES analysis might serve as a better model of the relationship between energy prices and investments in energy efficiency within a class of industries. The supply curves used in the LIEF model were developed using information from three sources: technology characterizations for sample subsectors, technology adoption behavior, and econometric analyses (Ross and Hwang 1992). These supply curves may be of interest in any efforts to reorganize the Fossil2 industrial module.

Reorganizing the Fossil2 industrial sector by industrial classes has several potential benefits. The model would be more precise and possibly more accurate if the level of its detail was refined. Not only would the model inputs be more precisely defined, but the degree of verisimilitude of 
the model results would be greatly enriched. The analyst would have a clearer picture of the industrial energy system results as projected by the model, which would help him or her in interpreting the results and supporting them to policy-makers.

Reorganization of the Fossil2 industrial sector based on industries would not be warranted if Fossil2 is not planned for extensive use in the future, especially in light of the Energy Information Administration's plans to develop a National Energy Modeling System.

\subsubsection{Reconfiguration of the Industrial Sector Into More Specific End-Uses}

An alternate approach to improving the specificity of Fossil2 modeling results is to break out more specific end-uses, such as motors and lighting. Such a reconfiguration would allow easier analysis of specific programs, for example, those directed at increasing the capital stock turnover rate (and, hence, the adoption rate of more efficient stock) for ubiquitous technologies such as motors. No fundamental changes to the model structure would be required, although additional conservation supply curves for the new end-uses would be needed. (Work in this area is currently planned--see Table 4.1.)

\subsubsection{Regionalization}

Fossil2 models the national energy economy as a single entity. Therefore, its assumptions about prices, stocks, resources, etc., are not distinguished by region. Often, policy-makers are not concerned solely with the effects of a policy on the nation as a whole: they are also concerned with the effects on various regions of the country. This is especially true of decision-makers in Congress, who are in office to represent the interests of their state or district.

The conceptual design for regionalizing Fossil2's industrial sector would not be difficult, but the scale of effort in terms of collecting data and calibrating the model would increase directly with the number of regions. Basically, the task would be to create an industrial sector, approximately equivalent in structure to the current version, for each of the regions in the model. Judicious use of arrays would facilitate the model coding, but it would not make the intellectual task of constructing the regionalized model with appropriate historical data and behavioral parameters any simpler.

The potential benefits of regionalizing the Fossil2 industrial sector include the ability to address the following: regional fuel availability and constraints, regional price differences, 
non-uniform growth in industries across regions, and impacts of policies on individual regions. Also, the model would operate at a greater degree of precision than the aggregate national model and would provide the analyst with more information to support the model's results to policy-makers.

\subsection{FINAL THOUGHTS}

The expected benefits of any specific industrial module development would, of course, have to be judged not only in terms of its own costs, but also in terms of the opportunity costs that affect the development of the rest of the model. Specific changes to the model's industrial sector may be desirable themselves, but resources (as well as computer memory) might be better applied to further developing other sectors of the model. Efforts to modify the industrial sector would only be successful if they were coordinated with the development of the other energy sectors in Fossil2.

In considering model development, we must remain cognizant of the limitations and simplifications that are inevitable in the process. Policy analysis models do not offer exact predictions about the future. Instead, they distill computationally complex situations into readily understandable and communicable results that offer some insight for decision-makers. Any decision to construct a model or further develop an existing model must be made in this context. 


\subsection{REFERENCES}

Applied Energy Services, Inc. (AES). 1987. Cverview of the Fossil 2 Demand Sector. Prepared for the U.S. Department of Energy by AES, Inc., Arlington, Virginia.

Applied Energy Services, Inc. (AES): 1991. Fossi2 Energy Policy Model Documented Listing. Prepared for the U.S. Department of Energy by AES, Inc., Arlington, Virginia.

Edmonds, J. A, and J. M. Reilly. 1985. Global Energy: Assessing the Future. Oxford University Press, New York.

Energy Information Administration (EIA). 1990. Assumptions for the Annual Energy Outlook 1990. DOE/ELA-0527-90. U.S. Energy Information Administration,' Washington, D.C.

Ross, M., and R. Hwang. 1992. A Model for Long-Term Industrial Energy Forecasting (LIEF). LBL-31861, Prepared for the U.S. Department of Energy by Lawrence Berkeley Laboratory, Berkeley, California.

U.S. Department of Energy (DOE). 1991a. Limiting Net Greenhouse Gas Emissions in the United States. DOE/PE-0101, Washington, D.C.

U.S. Department of Energy (DOE). 1991b. National Eneroy Strategy Technical Annex 2-Integrated Analysis Supporting the National Energy Strategy: Methodology, Assumptions, and Results. DOE/S-0086P, Washington, D.C.

Varian, H.R. 1984. Microeconomic Analysis. W.W. Norton \& Company, New York. 
APPENDIX A

DETAILED FOSSIL2 RESULTS FOR VARIOUS CASES 


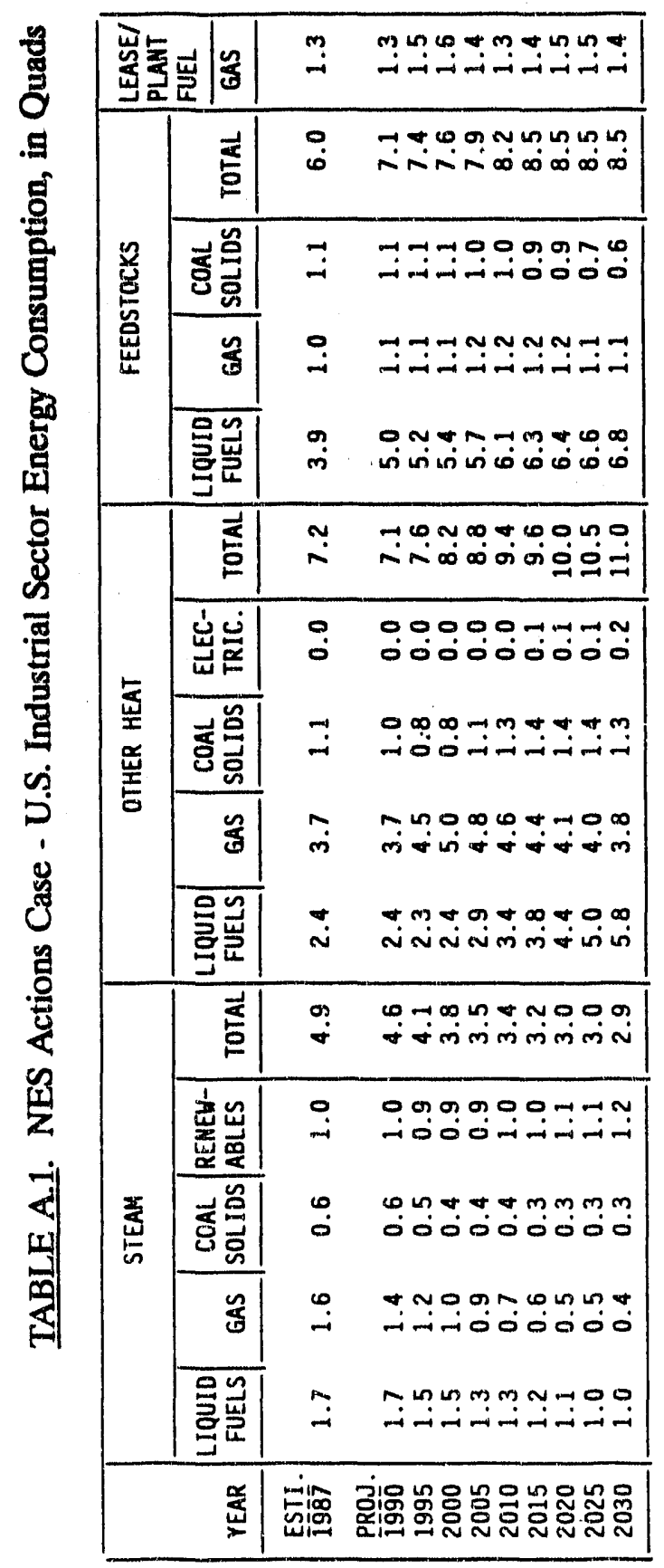

\begin{tabular}{|c|c|c|c|}
\hline \multirow{6}{*}{ 家 } & 点 & $\dot{d}$ & 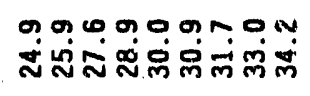 \\
\hline & 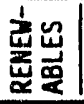 & $\stackrel{\infty}{-i}$ & 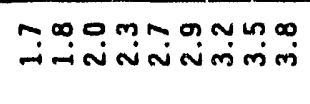 \\
\hline & 岁总 & $\stackrel{\sigma}{\sim}$ & 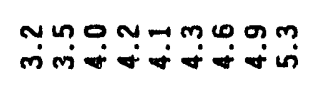 \\
\hline & 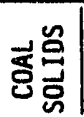 & $\dot{0}$ & م \\
\hline & 验 & $\vec{\infty}$ & 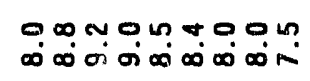 \\
\hline & 올 & $\vec{\infty}$ & 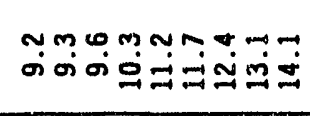 \\
\hline 侻 & 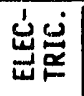 & $\dddot{i}$ & 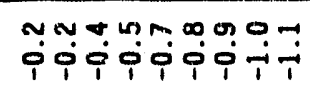 \\
\hline \multirow{5}{*}{ 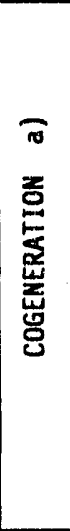 } & 站 & $\dot{-}$ & 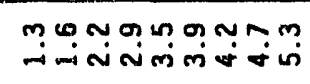 \\
\hline & 옳 & $\stackrel{\infty}{\circ}$ & ڤ̊̊ \\
\hline & 离哭总 & $\dddot{\sim}$ & 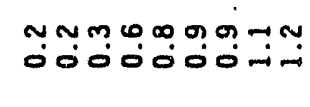 \\
\hline & ๘ & $\ddot{\circ}$ & 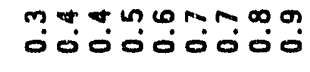 \\
\hline & 올 & $\overrightarrow{0}$ & ف \\
\hline \multirow{5}{*}{ 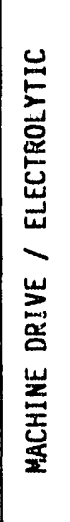 } & E & $\dot{m}$ & 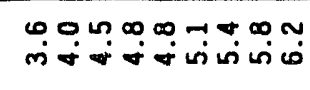 \\
\hline & 岂莡 & $\stackrel{\circ}{m}$ & 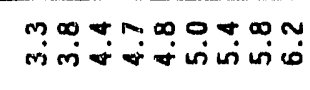 \\
\hline & 鸪总 & $\overrightarrow{0}$ & 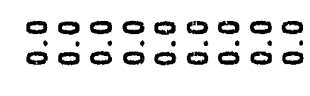 \\
\hline & 尔 & $\dddot{0}$ & 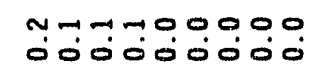 \\
\hline & 울룰 & $\overrightarrow{0}$ & 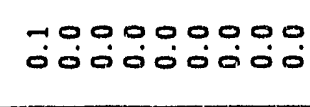 \\
\hline & $\stackrel{\dddot{\Im}}{\varpi}$ & \multicolumn{2}{|c|}{ 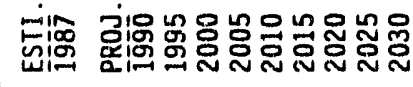 } \\
\hline
\end{tabular}




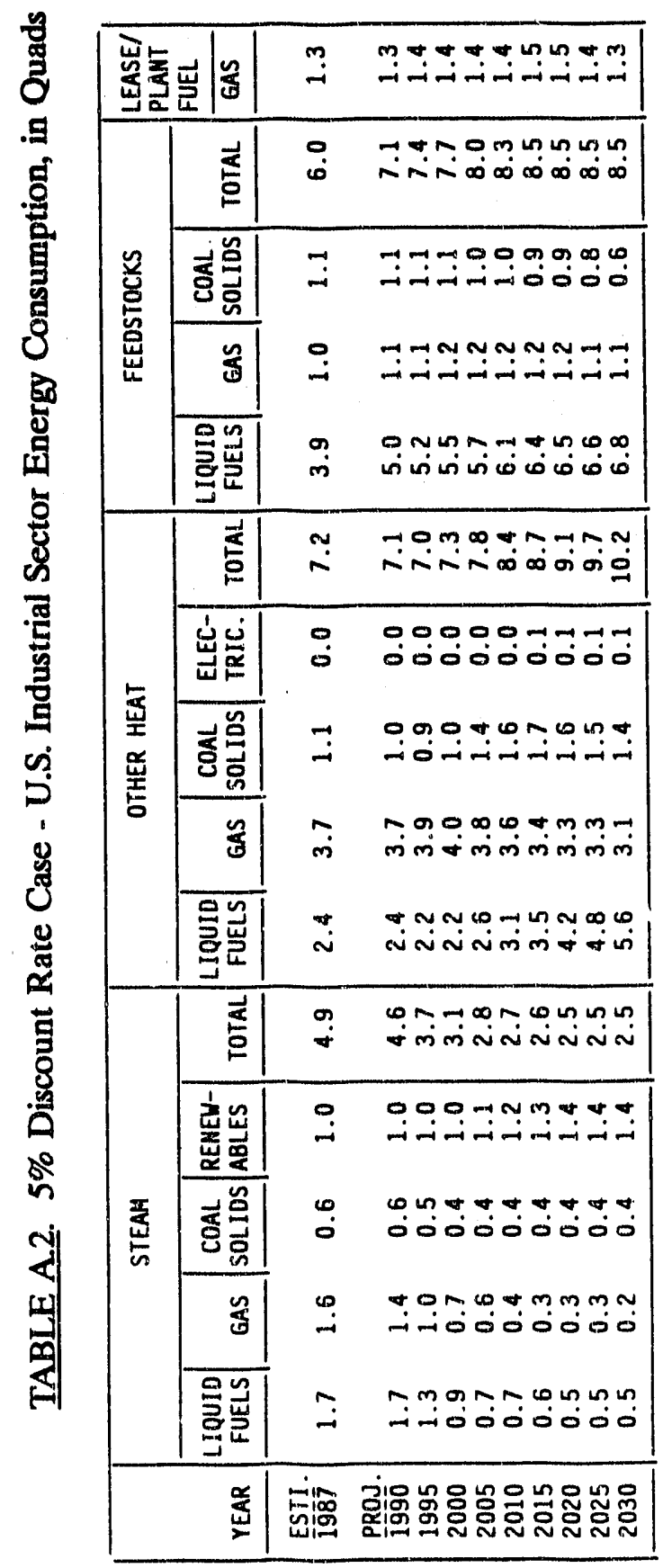

\begin{tabular}{|c|c|c|c|}
\hline \multirow{6}{*}{$\frac{1}{\sigma}$} & 志 & $\begin{array}{l}\stackrel{0}{d} \\
\text { d }\end{array}$ & 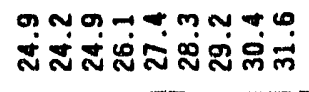 \\
\hline & 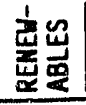 & $\stackrel{\infty}{-1}$ & تُ \\
\hline & 出递 & $\stackrel{0}{\sim}$ & 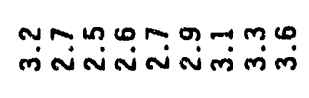 \\
\hline & 责号号 & $\ddot{m}$ & 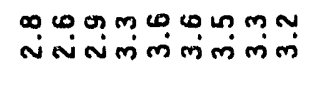 \\
\hline & 电 & $\vec{\infty}$ & 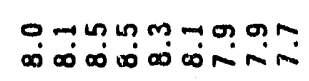 \\
\hline & 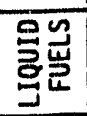 & $\vec{\infty}$ & 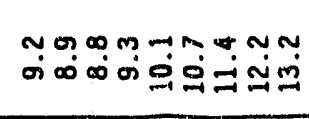 \\
\hline 통 & 岁莡 & $\dddot{i}$ & مَّ \\
\hline \multirow{5}{*}{ 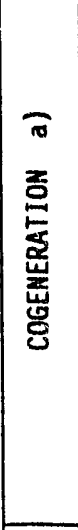 } & $\frac{1}{5}$ & $\stackrel{+}{-i}$ & 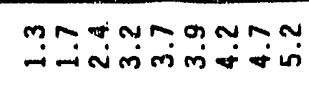 \\
\hline & 它䍃 & $\stackrel{\infty}{0}$ & 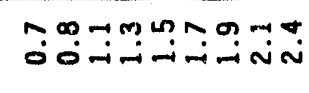 \\
\hline & 㤩号 & $\dddot{n}$ & نُ \\
\hline & 告 & $\ddot{0}$ & 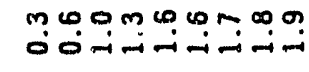 \\
\hline & 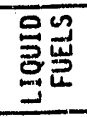 & $\overrightarrow{0}$ & 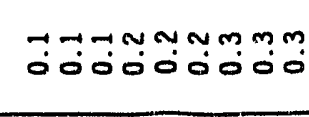 \\
\hline \multirow{5}{*}{ 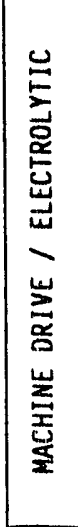 } & 茞 & $\stackrel{m}{m}$ & 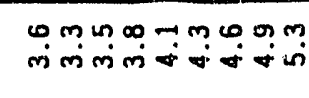 \\
\hline & 出出 & $\dot{m}$ & 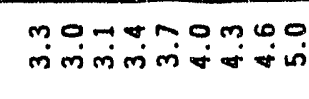 \\
\hline & 突苛 & $\overrightarrow{0}$ & 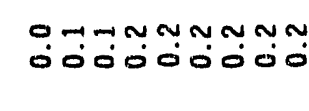 \\
\hline & 従 & $\dddot{0}$ & 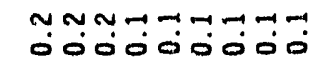 \\
\hline & 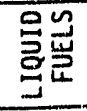 & $\ddot{0}$ & 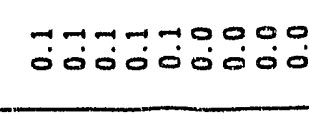 \\
\hline & 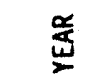 & 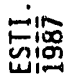 & 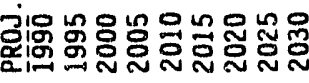 \\
\hline
\end{tabular}




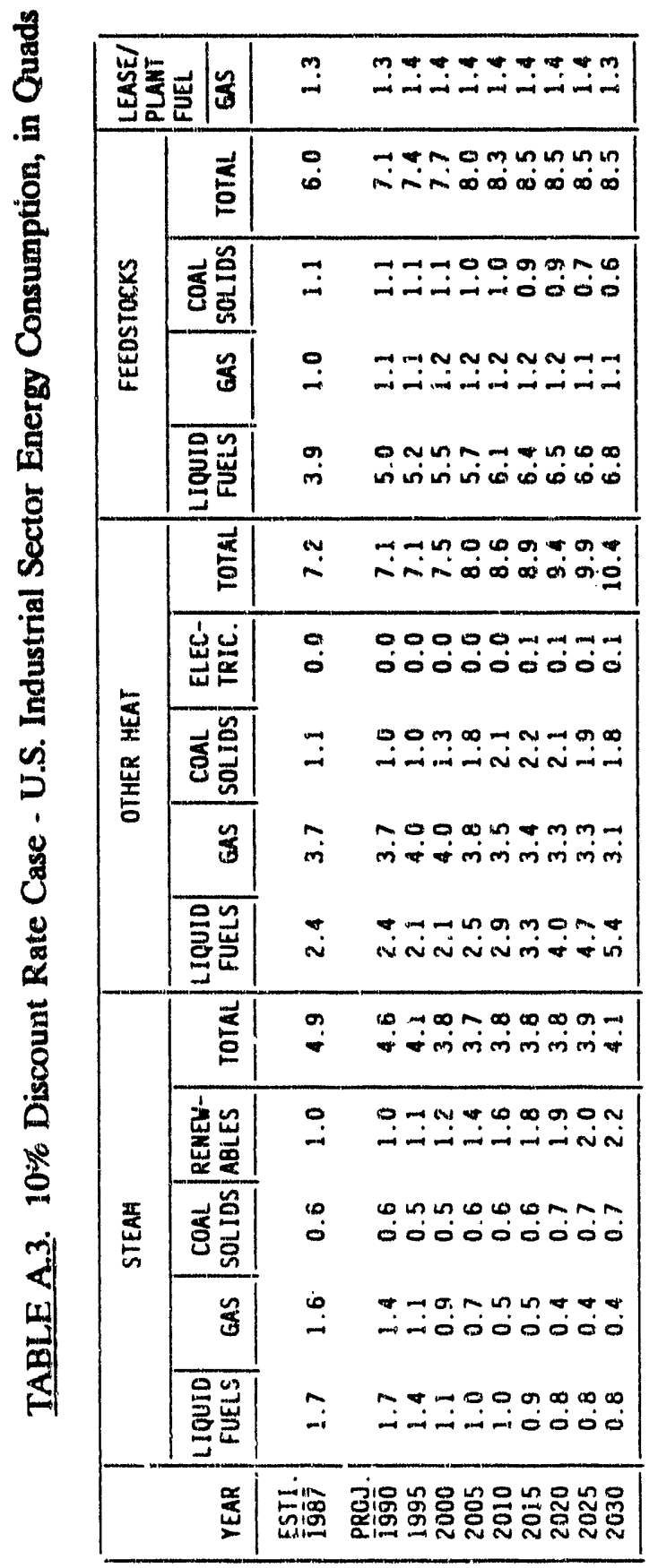

\begin{tabular}{|c|c|c|c|}
\hline \multirow{6}{*}{$\frac{1}{\frac{a}{6}}$} & 疍 & $\dot{\sim}$ & 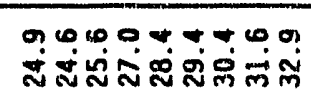 \\
\hline & 竞出 & $\stackrel{\infty}{\infty}$ & \\
\hline & 岂莡 & $\ddot{n}$ & 我 \\
\hline & 考号 & $\stackrel{p}{m}$ & 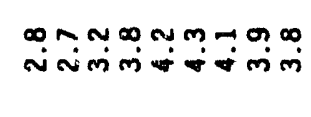 \\
\hline & 氕 & $m$ & ס \\
\hline & 을 & $\dddot{m}$ & $\begin{array}{l}\sim \\
\sigma \infty \\
\sigma \infty\end{array}$ \\
\hline 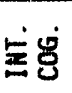 & 总娄 & $\dddot{i}$ & 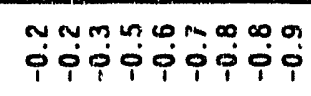 \\
\hline \multirow{5}{*}{ 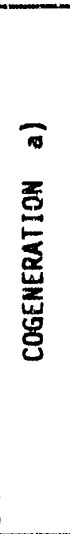 } & 点 & 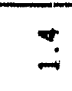 & 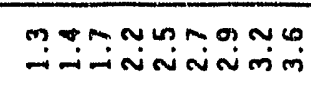 \\
\hline & 放愛 & 車 & 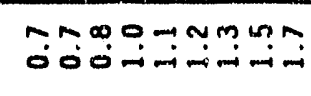 \\
\hline & 超骂 & $\dddot{0}$ & ن \\
\hline & 造 & $\ddot{\circ}$ & 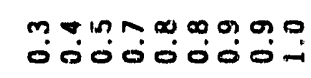 \\
\hline & 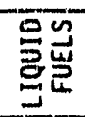 & $\ddot{0}$ & تَّ \\
\hline \multirow{5}{*}{ 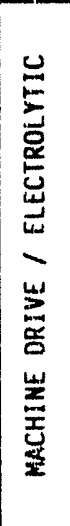 } & 롱 & $m$ & $\begin{array}{l}\infty \text { m } \\
\text { minim }\end{array}$ \\
\hline & 出䓵 & $\dot{m}$ & 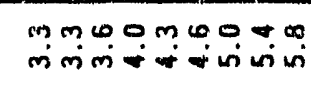 \\
\hline & 䨖骂 & $\ddot{0}$ & 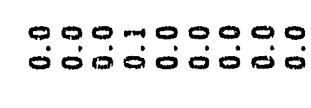 \\
\hline & $\tilde{\mho}$ & $\ddot{0}$ & 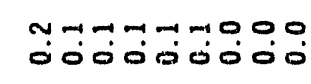 \\
\hline & 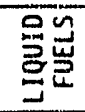 & $\overrightarrow{0}$ & $\begin{array}{l}\text { ت000000000 } \\
\text { ப00000000 }\end{array}$ \\
\hline & $\frac{a}{\frac{2}{x}}$ & \multicolumn{2}{|c|}{ 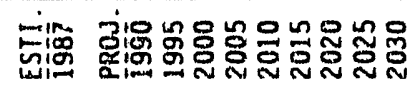 } \\
\hline
\end{tabular}




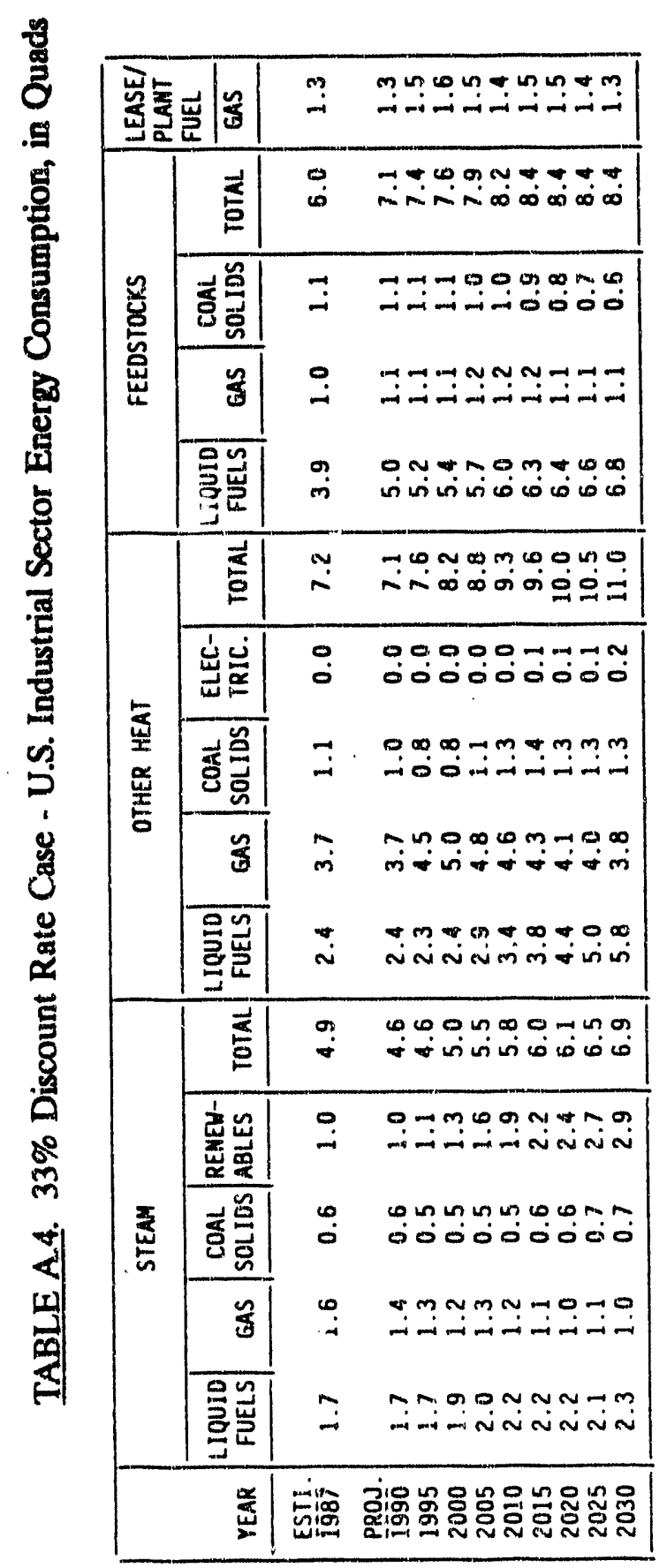

\begin{tabular}{|c|c|c|c|}
\hline \multirow{6}{*}{ 忞 } & $\frac{1}{6}$ & $\stackrel{\dot{0}}{\dot{\sim}}$ & 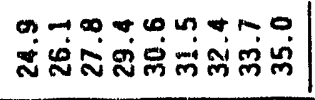 \\
\hline & 焉点 & $\stackrel{\infty}{-1}$ & 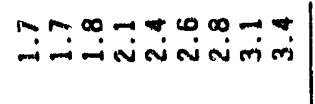 \\
\hline & 出岱 & $\stackrel{n}{\sim}$ & 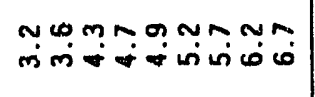 \\
\hline & 我总 & $\ddot{\dot{m}}$ & 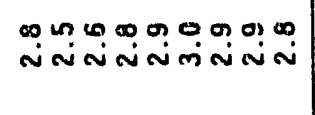 \\
\hline & 莍 & $\vec{\infty}$ & 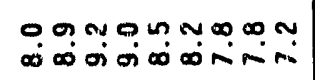 \\
\hline & 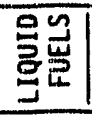 & $\vec{\infty}$ & 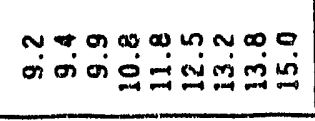 \\
\hline 递它 & 岂点总 & $\dddot{i}$ & 审审审审审审审 \\
\hline \multirow{5}{*}{ 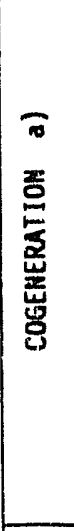 } & 宓 & 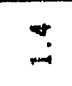 & 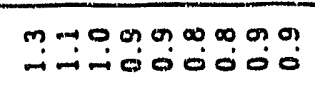 \\
\hline & de $\frac{n}{\tilde{c}}$ & $\begin{array}{l}\infty \\
0\end{array}$ & 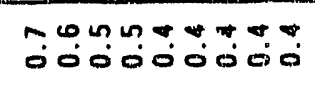 \\
\hline & 总骂 & $\dddot{0}$ & نَّ \\
\hline & $\tilde{\Xi}$ & $\dot{0}$ & 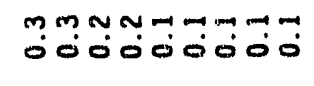 \\
\hline & 올를 & $\ddot{0}$ & \\
\hline \multirow{5}{*}{ 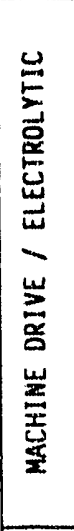 } & 站 & $\dot{m}$ & 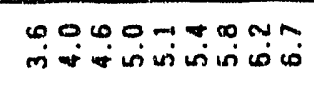 \\
\hline & 总点 & $\dot{m}$ & 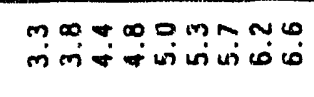 \\
\hline & 常总总 & $\ddot{0}$ & $\begin{array}{l}000000000 \\
000000000\end{array}$ \\
\hline & $\tilde{\pi}$ & $\stackrel{y}{0}$ & \\
\hline & 品岂 & "ே & 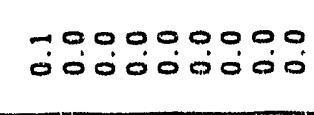 \\
\hline & 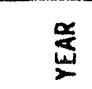 & 至is & 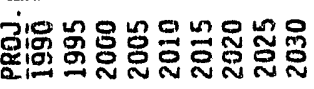 \\
\hline
\end{tabular}




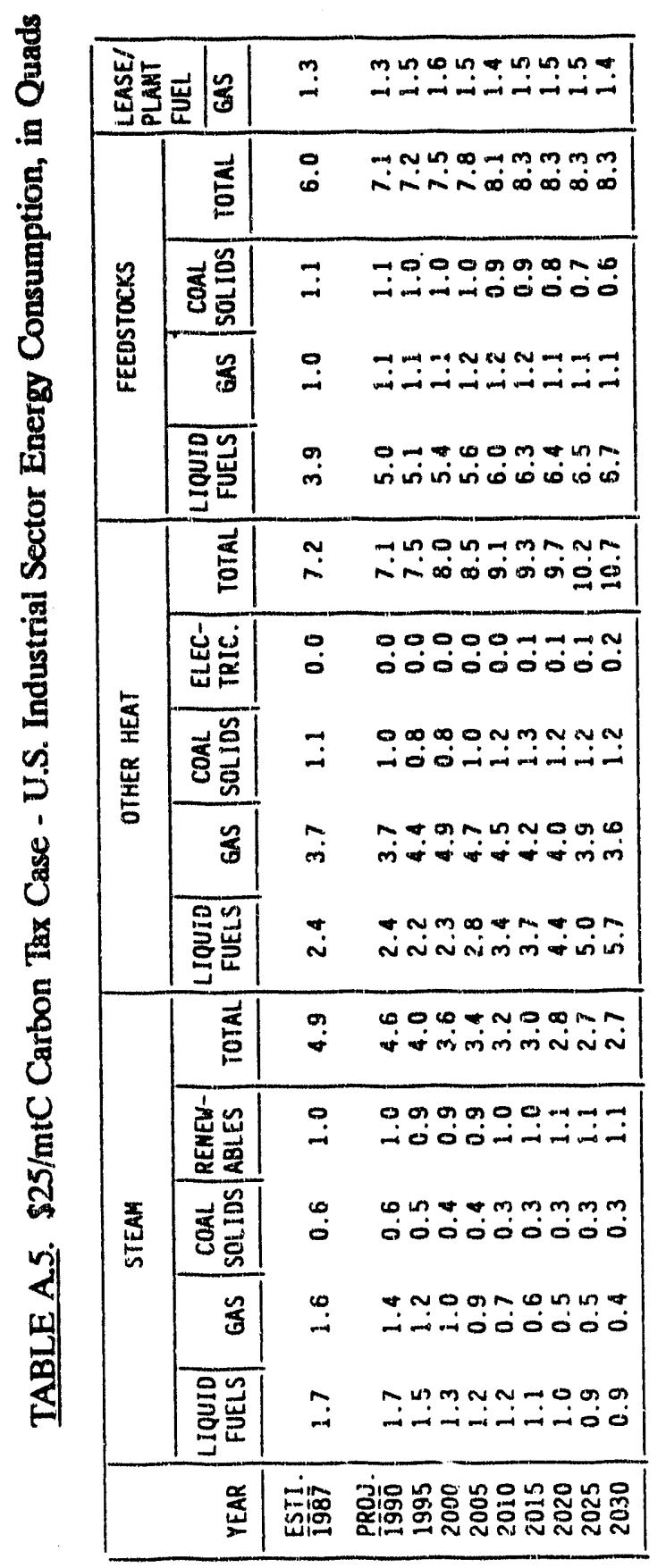

\begin{tabular}{|c|c|c|c|}
\hline \multirow{6}{*}{ 点 } & 妾 & $\frac{i}{n}$ & 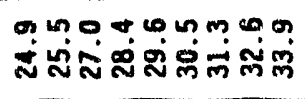 \\
\hline & 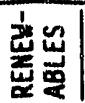 & $\stackrel{\infty}{-}$ & 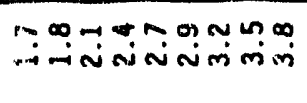 \\
\hline & 岂雚 & $\stackrel{n}{i}$ & 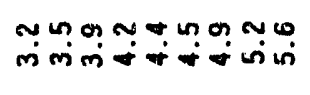 \\
\hline & 起管 & $\stackrel{\circ}{\dot{m}}$ & 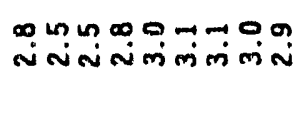 \\
\hline & 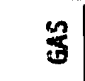 & $\vec{\infty}$ & 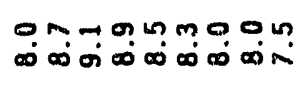 \\
\hline & 高岂 & $\vec{\infty}$ & 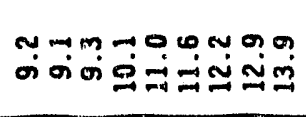 \\
\hline 辰 & 岂芦 & $\dddot{i}$ & بَّ \\
\hline \multirow{5}{*}{ 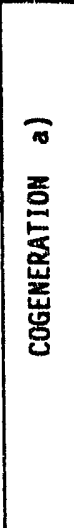 } & $\frac{\vec{a}}{5}$ & $\square$ & تُ \\
\hline & 它幾 & $\stackrel{\infty}{0}$ & måñ \\
\hline & 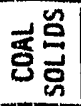 & $\stackrel{\sim}{0}$ & 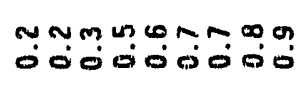 \\
\hline & 旾 & $\stackrel{t}{\circ}$ & 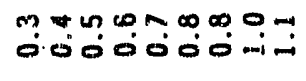 \\
\hline & 产岂 & $\overrightarrow{0}$ & 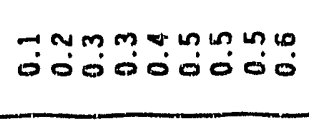 \\
\hline \multirow{5}{*}{ 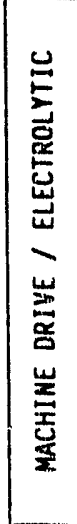 } & 胥 & $\stackrel{m}{m}$ & 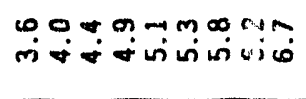 \\
\hline & 岀兽 & $\stackrel{\dot{m}}{\dot{m}}$ & mimmmomprom \\
\hline & 芯管 & $\ddot{0}$ & $\begin{array}{l}0009000000 \\
00000000\end{array}$ \\
\hline & \% & $\dddot{\infty}$ & 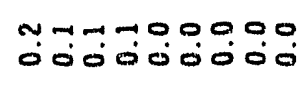 \\
\hline & 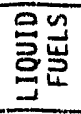 & $\overline{0}$ & 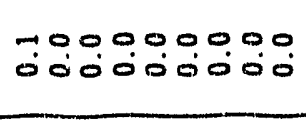 \\
\hline & 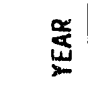 & \multicolumn{2}{|c|}{ 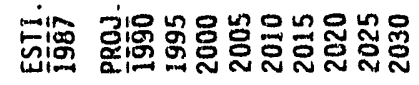 } \\
\hline
\end{tabular}




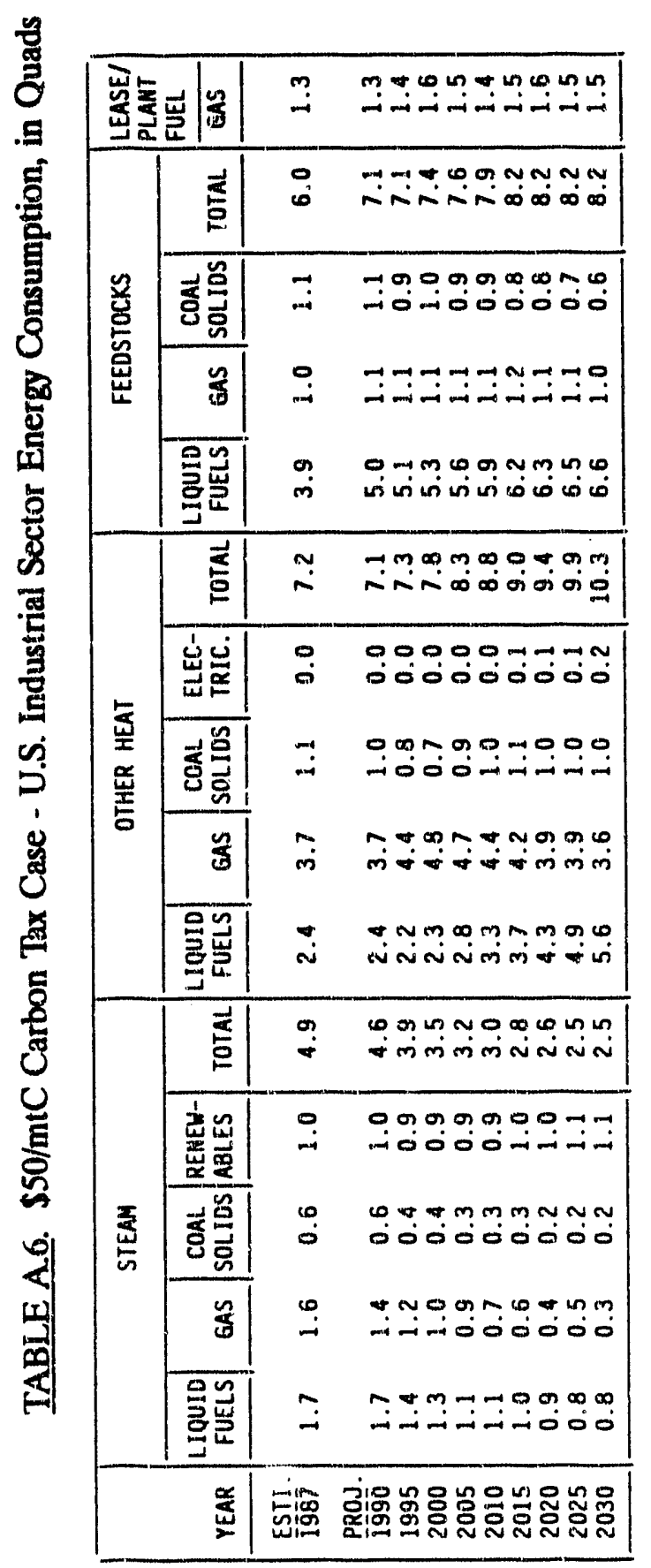

\begin{tabular}{|c|c|c|c|}
\hline \multirow{6}{*}{ 宧 } & $\frac{1}{5}$ & 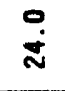 & 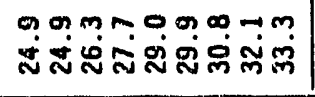 \\
\hline & 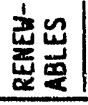 & $\stackrel{\infty}{m}$ & 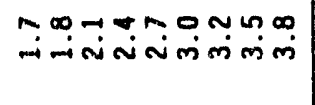 \\
\hline & 出車 & $\stackrel{m}{\sim}$ & 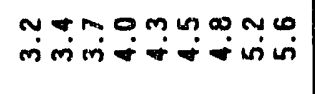 \\
\hline & 范葛 & $\stackrel{\square}{\dot{m}}$ & 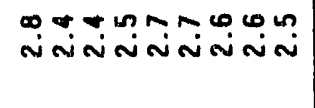 \\
\hline & $\frac{\pi}{6}$ & $\ddot{\infty}$ & 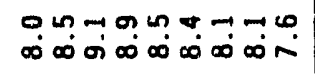 \\
\hline & 象咅 & $\vec{\infty}$ & ஸ̣ळ \\
\hline$\leq \dot{0}$ & 总它 & $\stackrel{\sim}{i}$ & 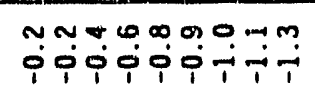 \\
\hline \multirow{5}{*}{ 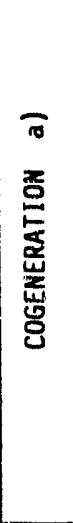 } & 志 & $\stackrel{\square}{\square}$ & m \\
\hline & 总蓝 & $\stackrel{\infty}{0}$ & نْ \\
\hline & 莡导 & $\stackrel{\sim}{0}$ & $\begin{array}{l}\text { Y } \\
0000000 \\
00000\end{array}$ \\
\hline & 苍 & $\dot{0}$ & سِ \\
\hline & 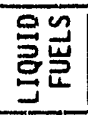 & $\ddot{0}$ & 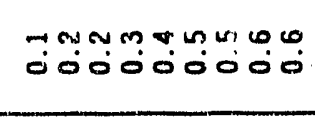 \\
\hline \multirow{5}{*}{ 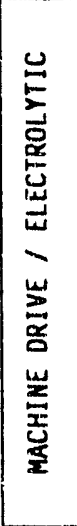 } & $\frac{1}{5}$ & $m$ & 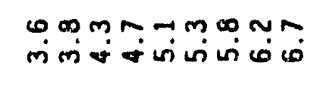 \\
\hline & 岂息 & or & 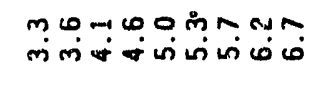 \\
\hline & 范泀 & $\overrightarrow{0}$ & 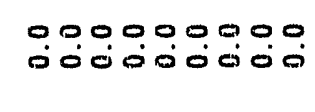 \\
\hline & 采 & $\dddot{0}$ & 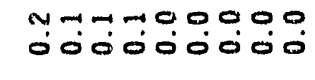 \\
\hline & 을 & $\overrightarrow{0}$ & $\begin{array}{l}\because 00000000 \\
000000000\end{array}$ \\
\hline & 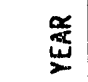 & 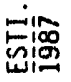 & 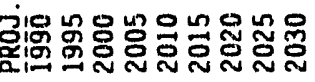 \\
\hline
\end{tabular}




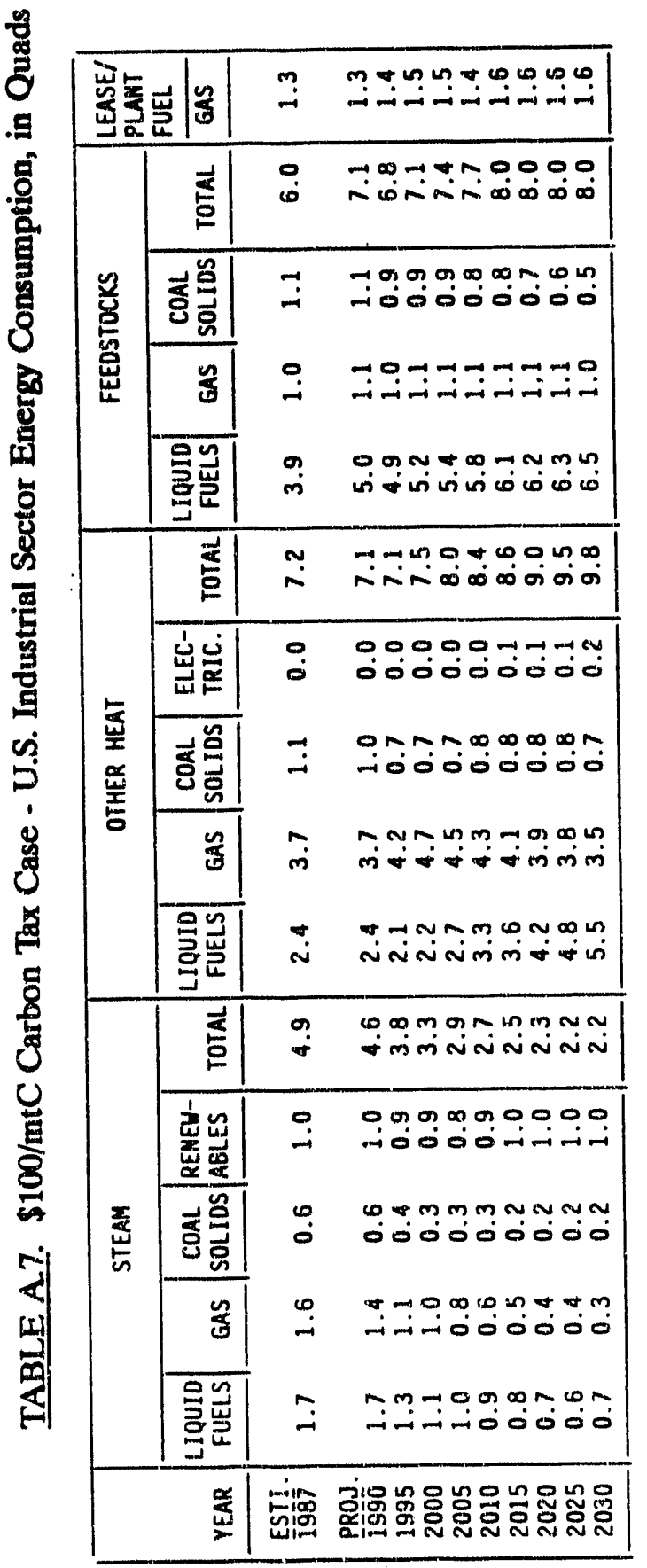

\begin{tabular}{|c|c|c|c|}
\hline \multirow{6}{*}{$\overrightarrow{\underline{E}}$} & $\vec{E}$ & $\stackrel{0}{i}$ & 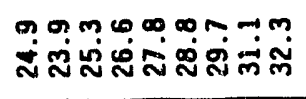 \\
\hline & 密岂| & $\stackrel{\infty}{\infty}$ & 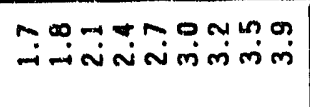 \\
\hline & 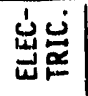 & $\stackrel{m}{i}$ & 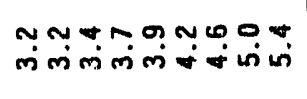 \\
\hline & 巻瓷 & $\stackrel{\circ}{m}$ & 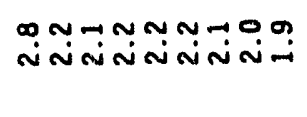 \\
\hline & 正 & $\vec{\infty}$ & 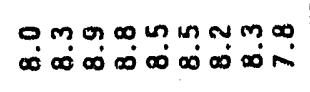 \\
\hline & 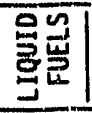 & $\vec{\infty}$ & 象 \\
\hline 풍 & 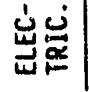 & $\dddot{i}$ & 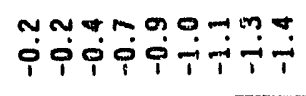 \\
\hline \multirow{5}{*}{ 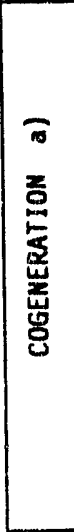 } & 疍 & $\dot{m}$ & 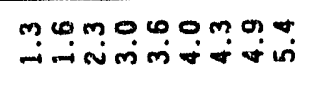 \\
\hline & 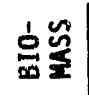 & $\stackrel{\infty}{0}$ & 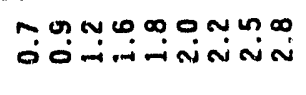 \\
\hline & 总总 & $\dddot{0}$ & مُ \\
\hline & 乌్s & $\stackrel{+}{0}$ & 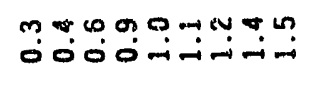 \\
\hline & 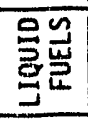 & $\overrightarrow{0}$ & 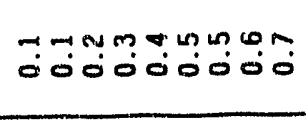 \\
\hline \multirow{5}{*}{ 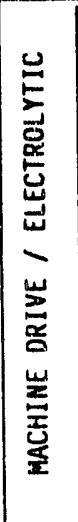 } & $\overrightarrow{\underline{\mathbb{a}}}$ & $\stackrel{m}{m}$ & فِ \\
\hline & 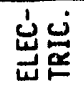 & $\stackrel{0}{m}$ & 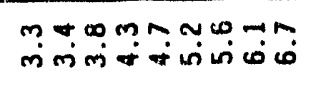 \\
\hline & 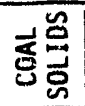 & $\overrightarrow{0}$ & $\begin{array}{l}000000000 \\
000000000\end{array}$ \\
\hline & $\frac{n}{0}$ & $\dddot{0}$ & 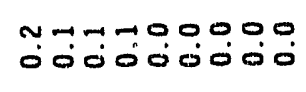 \\
\hline & 旁岂 & $\ddot{0}$ & 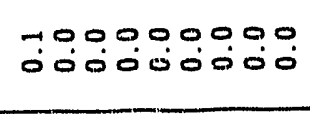 \\
\hline & 愛 & \multicolumn{2}{|c|}{ 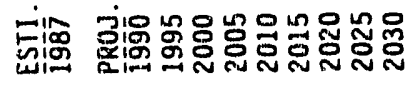 } \\
\hline
\end{tabular}




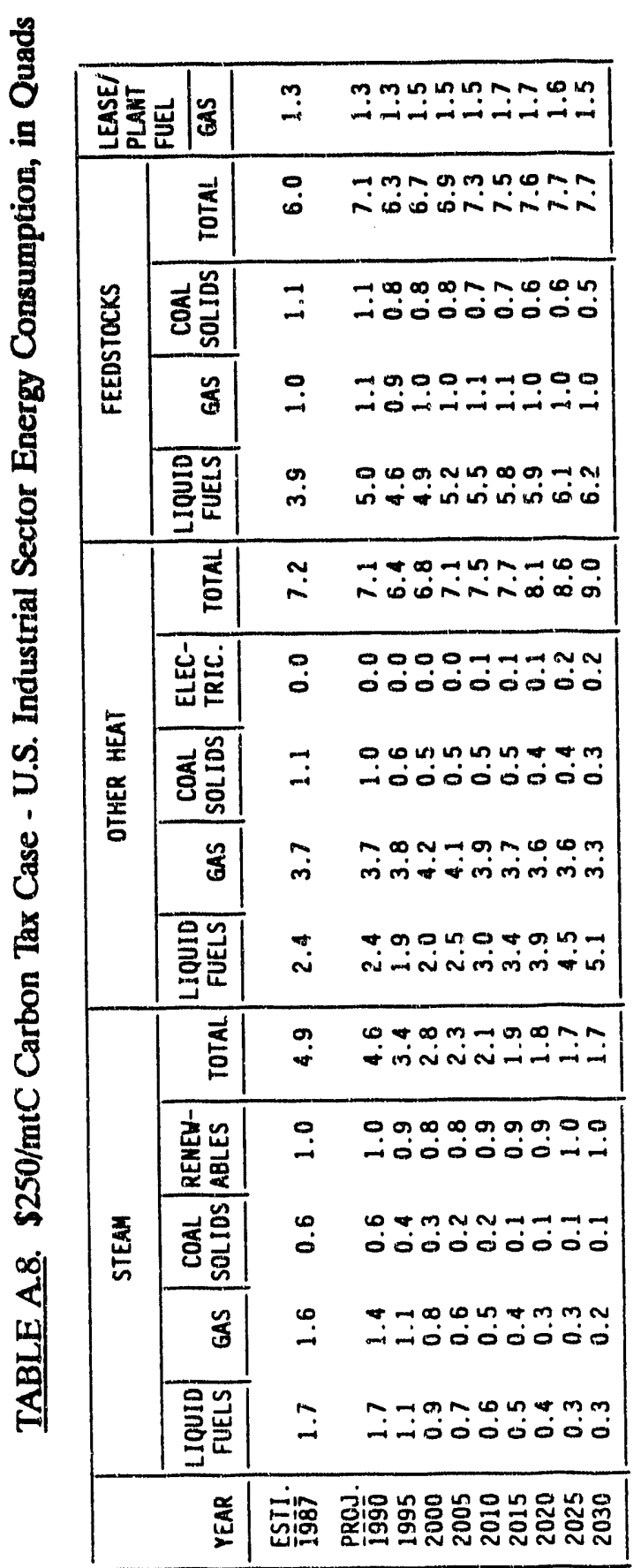

\begin{tabular}{|c|c|c|c|}
\hline \multirow{6}{*}{ 衣 } & ह & $\begin{array}{l}0 \\
\dot{\Delta}\end{array}$ & 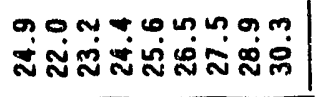 \\
\hline & 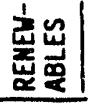 & $\stackrel{\infty}{-\infty}$ & 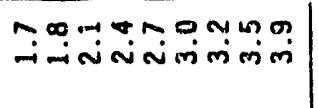 \\
\hline & 岂葛 & on & Nִ \\
\hline & 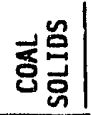 & $\stackrel{\circ}{\dot{m}}$ & $\stackrel{\infty}{\sim}$ \\
\hline & 路 & $\vec{\infty}$ & 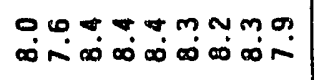 \\
\hline & 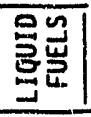 & $\vec{\infty}$ & 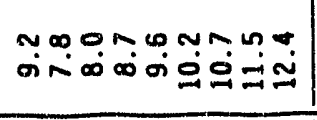 \\
\hline$\sum \dot{\Xi}$ & 岂雚| & $\underset{1}{\sim}$ & 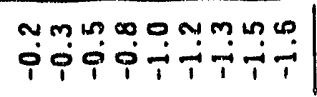 \\
\hline \multirow{5}{*}{ 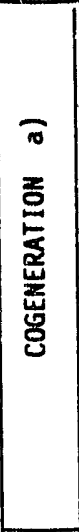 } & 起 & $\stackrel{\square}{-}$ & 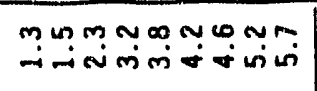 \\
\hline & 응 & 足 & 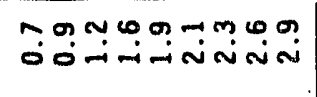 \\
\hline & 总总 & $\stackrel{\sim}{0}$ & نَّ \\
\hline & 色 & $\stackrel{+}{0}$ & 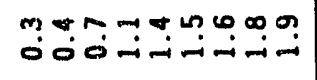 \\
\hline & 을 & $\overrightarrow{0}$ & 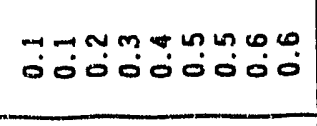 \\
\hline \multirow{5}{*}{ 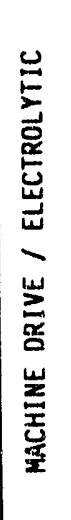 } & 志 & 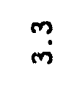 & mm \\
\hline & 岂完 & $\stackrel{\circ}{\dot{m}}$ & "ُ \\
\hline & 悹荢 & $\overrightarrow{0}$ & $\begin{array}{l}00000000 \\
000000000\end{array}$ \\
\hline & है & بَ & مُ0ّة \\
\hline & 읔욜 & $\overrightarrow{0}$ & 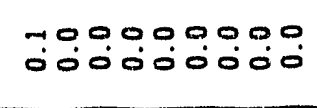 \\
\hline & 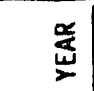 & - تئí & 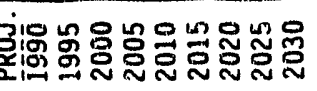 \\
\hline
\end{tabular}




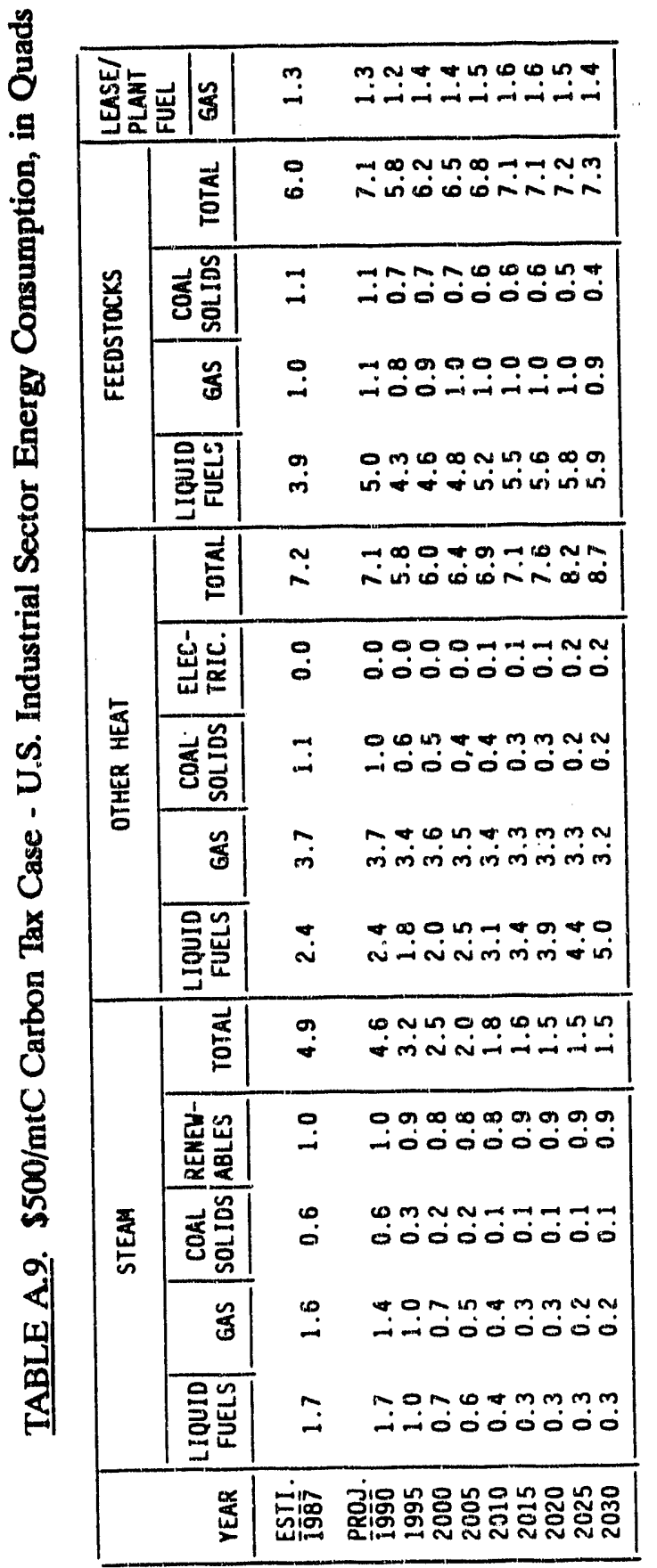

\begin{tabular}{|c|c|c|c|}
\hline \multirow{6}{*}{ 胥 } & 点 & $\stackrel{0}{\dot{D}}$ & क \\
\hline & 焉出 & $\stackrel{\infty}{-}$ & 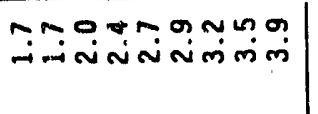 \\
\hline & 出点 & $\stackrel{n}{n}$ & ஸn் \\
\hline & 卖点 & $\stackrel{0}{m}$ & 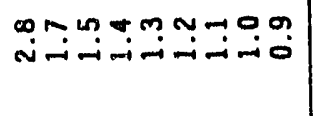 \\
\hline & 氕 & $\ddot{\infty}$ & $\begin{array}{lll}0 \\
\infty \\
\infty\end{array}$ \\
\hline & 올멸 & $\ddot{\infty}$ & 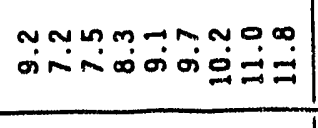 \\
\hline 意总 & 岀葆 & $\dddot{i}$ & 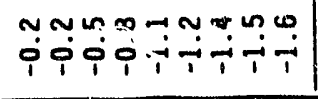 \\
\hline \multirow{5}{*}{ 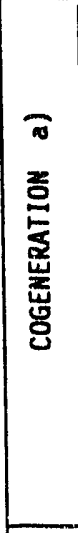 } & 岕 & $\stackrel{\square}{-}$ & 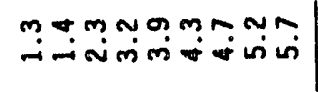 \\
\hline & $\log _{\infty}^{\infty}$ & $\stackrel{\infty}{0}$ & \\
\hline & 起骂 & $\dddot{0}$ & 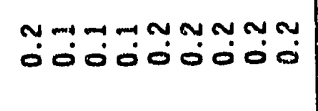 \\
\hline & 告 & $\ddot{0}$ & 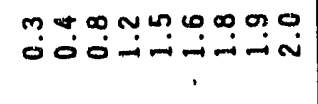 \\
\hline & 을멸 & $\ddot{0}$ & 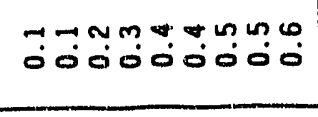 \\
\hline \multirow{5}{*}{ 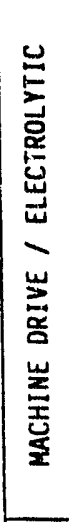 } & $\frac{1}{2}$ & $\stackrel{m}{m}$ & فํ. \\
\hline & 总总 & $\stackrel{0}{m}$ & mீm \\
\hline & 离骂 & $\overrightarrow{0}$ & 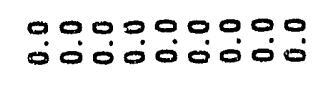 \\
\hline & 品 & $\dddot{0}$ & 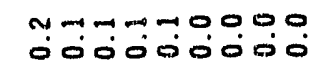 \\
\hline & 氛岂 & $\ddot{0}$ & 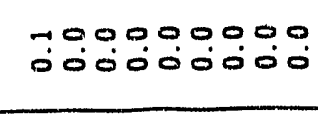 \\
\hline & $\frac{\alpha}{\frac{\alpha}{2}}$ & 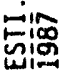 & 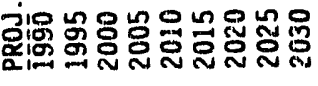 \\
\hline
\end{tabular}




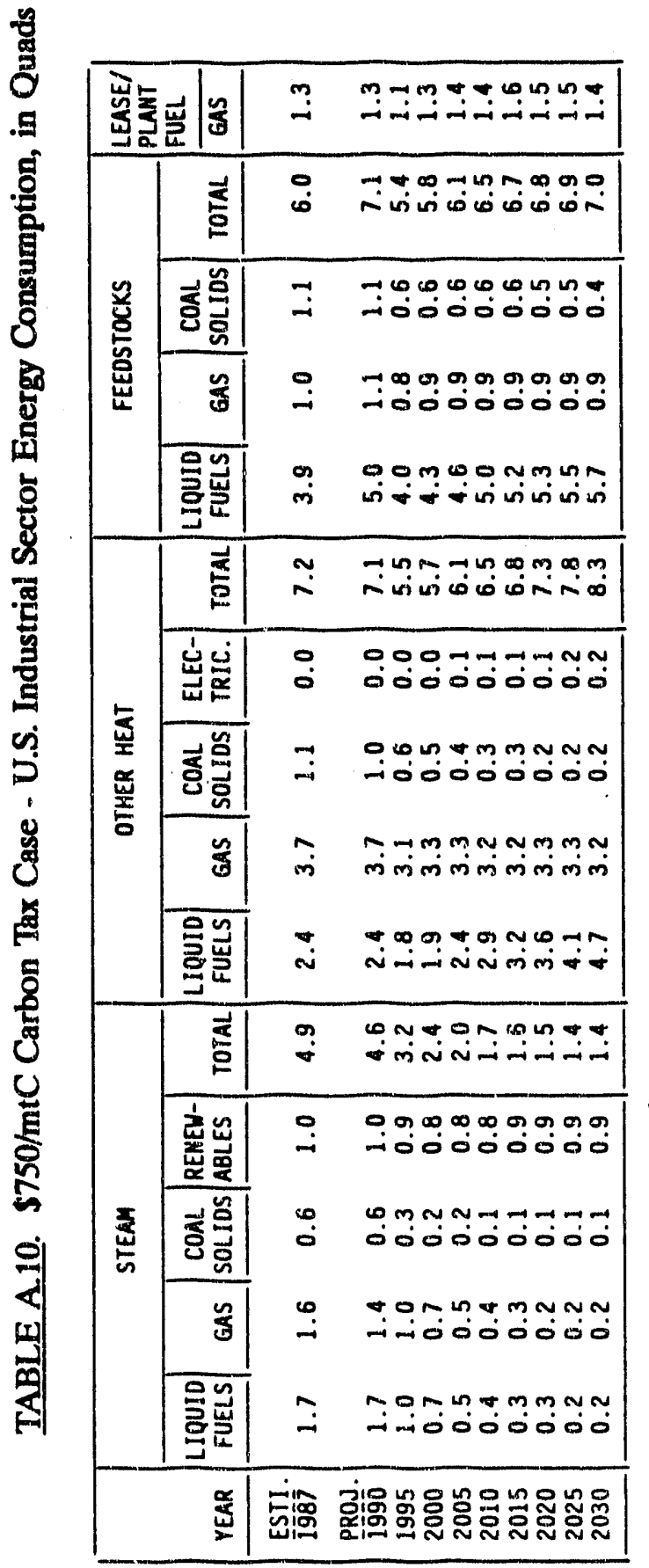

\begin{tabular}{|c|c|c|c|}
\hline \multirow{6}{*}{ 芯 } & है & & 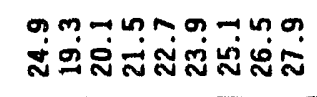 \\
\hline & 立热 & $\stackrel{\infty}{-}$ & 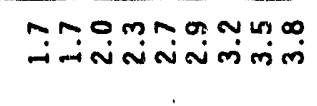 \\
\hline & 出苔 & $\ddot{\sim}$ & 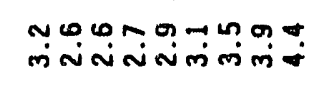 \\
\hline & 范总 & $\dot{0}$ & فّ \\
\hline & $\frac{n}{5}$ & $\ddot{\infty}$ & 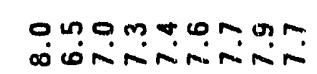 \\
\hline & 总出 & $\vec{\infty}$ & 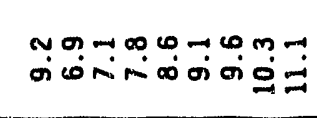 \\
\hline 힌 & 出莡 & $\dddot{0}$ & 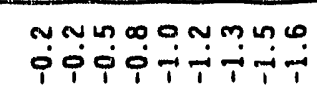 \\
\hline \multirow{5}{*}{ 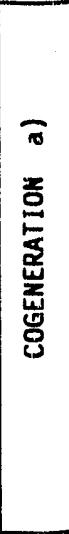 } & E & $\stackrel{\square}{-}$ & "r \\
\hline & 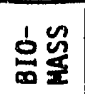 & $\begin{array}{l}\infty \\
0\end{array}$ & 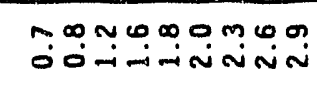 \\
\hline & 吾员 & $\dddot{0}$ & 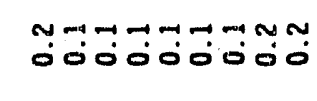 \\
\hline & $\tilde{\Xi}$ & $\dot{0}$ & mั0் \\
\hline & 올 & $\ddot{0}$ & 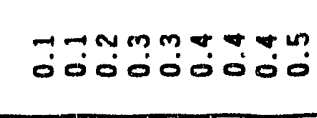 \\
\hline \multirow{5}{*}{ 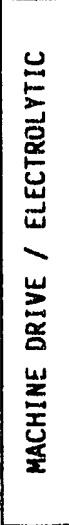 } & 趈 & $\stackrel{m}{m}$ & ن \\
\hline & 怠总 & o. & 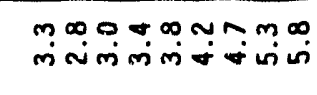 \\
\hline & 豆骂总 & $\ddot{0}$ & 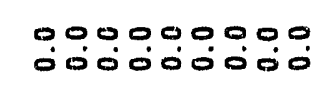 \\
\hline & 告 & $\dddot{0}$ & 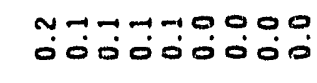 \\
\hline & 을 & $\overrightarrow{0}$ & 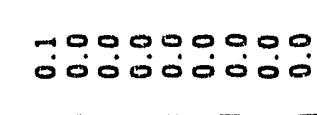 \\
\hline & 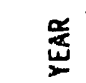 & \multicolumn{2}{|c|}{ 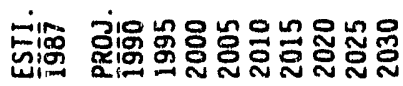 } \\
\hline
\end{tabular}




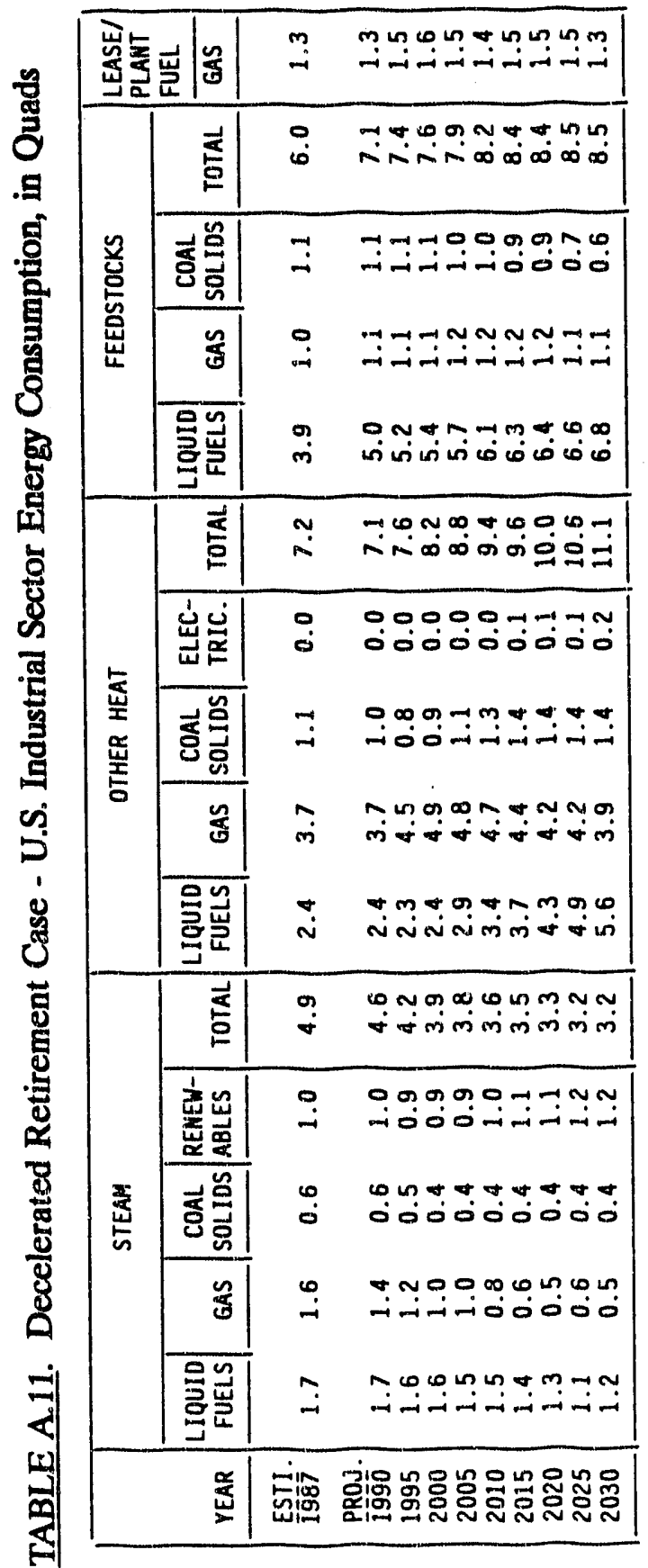

\begin{tabular}{|c|c|c|c|}
\hline \multirow{6}{*}{ 㭚 } & 点 & 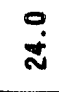 & 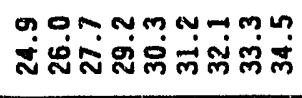 \\
\hline & 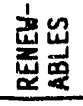 & $\stackrel{\infty}{-\infty}$ & 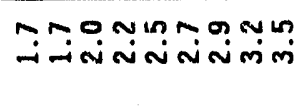 \\
\hline & 总总 & $\stackrel{\infty}{\sim}$ & ن \\
\hline & 霑骂 & $\stackrel{0}{\dot{m}}$ & 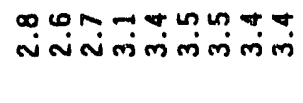 \\
\hline & ชै & $\vec{\infty}$ & 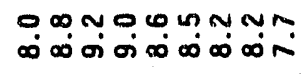 \\
\hline & 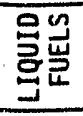 & $\vec{\infty}$ & 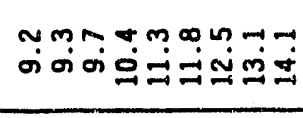 \\
\hline 158 & 出芯 & $\stackrel{\sim}{1}$ & نَّ \\
\hline \multirow{5}{*}{$\begin{array}{l}\overline{0} \\
\text { ż } \\
\text { 总 } \\
\text { 总 } \\
\text { 总 }\end{array}$} & $\frac{\vec{\alpha}}{E}$ & $\stackrel{\square}{-}$ & 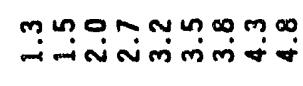 \\
\hline & 家出 & $\begin{array}{l}\infty \\
0 \\
0\end{array}$ & نُ \\
\hline & 㤩哭 & $\stackrel{0}{0}$ & نَهْ \\
\hline & है & $\ddot{0}$ & 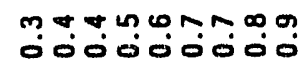 \\
\hline & 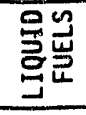 & $\overrightarrow{0}$ & 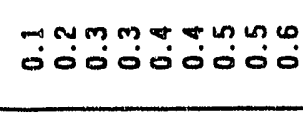 \\
\hline \multirow{5}{*}{ 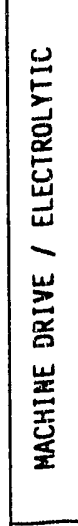 } & 恋 & $\dot{m}$ & 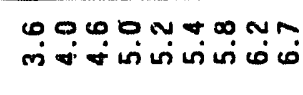 \\
\hline & 出若 & $\stackrel{0}{\dot{m}}$ & 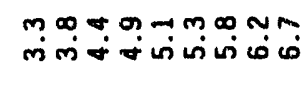 \\
\hline & 递总 & $\overrightarrow{0}$ & 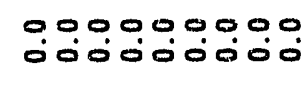 \\
\hline & 告 & $\ddot{0}$ & 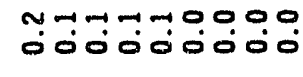 \\
\hline & 号出 & $\overrightarrow{0}$ & $\begin{array}{l}\text {-00000000 } \\
000000000 \\
000\end{array}$ \\
\hline & $\stackrel{\frac{\alpha}{5}}{\frac{w}{2}}$ & 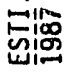 & 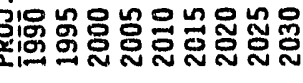 \\
\hline
\end{tabular}




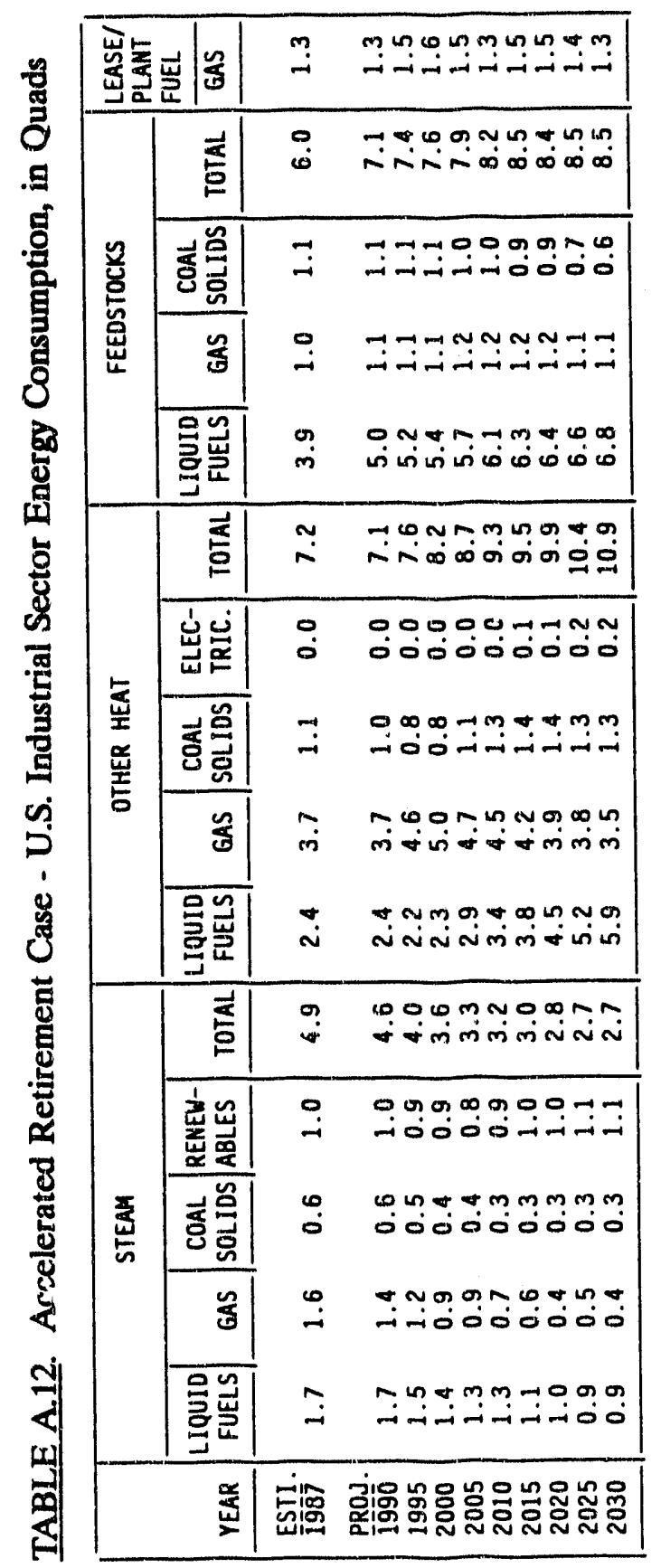

\begin{tabular}{|c|c|c|c|}
\hline \multirow{6}{*}{ 志 } & $\frac{1}{\not}$ & $\frac{0}{\dot{N}}$ & 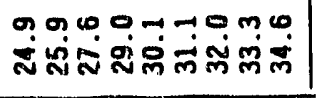 \\
\hline & 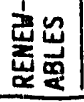 & $\stackrel{\infty}{-i}$ & 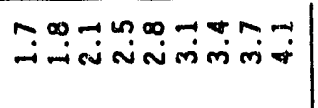 \\
\hline & 岂总 & $\stackrel{n}{\sim}$ & 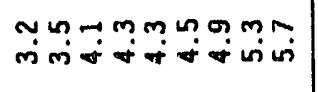 \\
\hline & 范恣 & $\stackrel{\circ}{\dot{m}}$ & 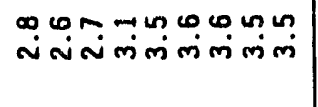 \\
\hline & $\mathcal{E}_{0}^{2}$ & $\vec{\infty}$ & 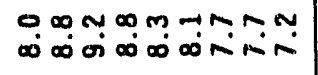 \\
\hline & 옿별 & $\vec{\infty}$ & 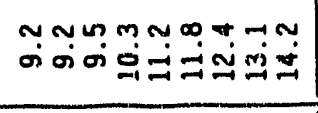 \\
\hline 家 & 岂总 & $\tilde{i}$ & 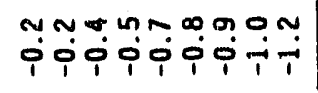 \\
\hline \multirow{5}{*}{ 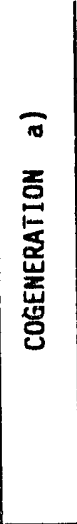 } & 至 & $\stackrel{\square}{\square}$ & भُ \\
\hline & 홍ํㄹ & $\stackrel{\infty}{\infty}$ & نَّ \\
\hline & 至骂 & $\dddot{0}$ & نَn \\
\hline & 结 & $\stackrel{\circ}{\circ}$ & 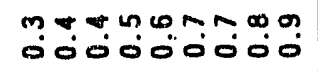 \\
\hline & 号出 & $\overrightarrow{0}$ & 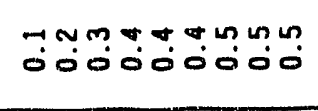 \\
\hline \multirow{5}{*}{ 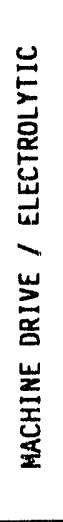 } & $\stackrel{\vec{\sigma}}{\Xi}$ & $\ddot{m}$ & فَّ \\
\hline & 岂莡 & $\ddot{m}$ & ضُ \\
\hline & 窎嵒 & $\ddot{0}$ & $\begin{array}{l}00000000 \\
00000000 \\
0000\end{array}$ \\
\hline & 行 & $\dddot{\sim}$ & 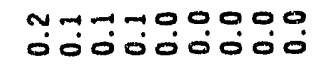 \\
\hline & 뫃몀 & $\overrightarrow{0}$ & 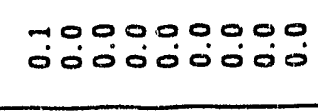 \\
\hline & 号 & \multicolumn{2}{|c|}{ 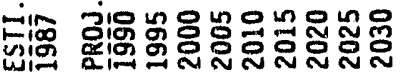 } \\
\hline
\end{tabular}




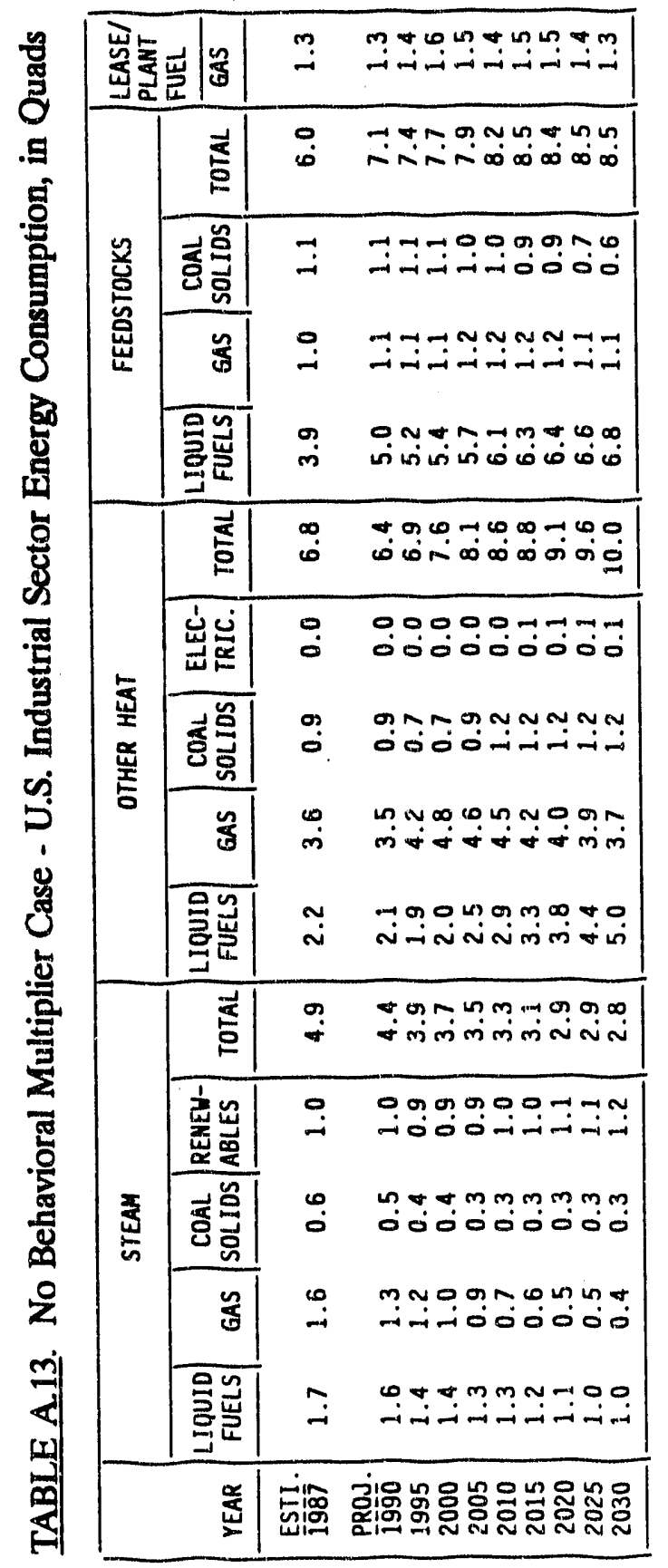

\begin{tabular}{|c|c|c|c|}
\hline \multirow{6}{*}{ 离 } & है। & $\stackrel{n}{n}$ & 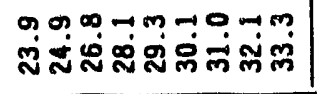 \\
\hline & 峑出 & $\stackrel{\infty}{\sim}$ & هُ \\
\hline & 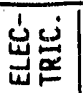 & $\ddot{\sim}$ & تُ \\
\hline & 衰哭号 & $\stackrel{\infty}{\sim}$ & 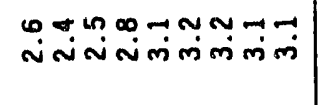 \\
\hline & 过 & $\stackrel{0}{\infty}$ & 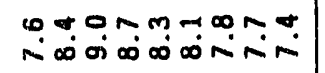 \\
\hline & 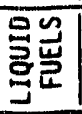 & ${ }_{\infty}^{0}$ & 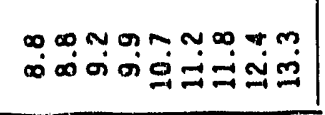 \\
\hline 远 & 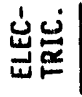 & $\dddot{i}$ & بَ \\
\hline \multirow{5}{*}{ 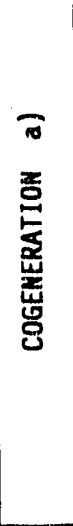 } & 类 & $\stackrel{\square}{-}$ & نُ \\
\hline & 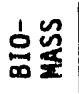 & $\stackrel{\infty}{\infty}$ & ڤ̊̆ \\
\hline & 哭总 & هִ & 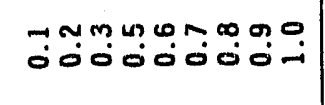 \\
\hline & $\frac{n}{6}$ & $\stackrel{5}{0}$ & 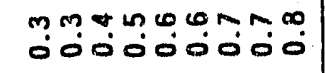 \\
\hline & 氛岂 & $\overrightarrow{0}$ & 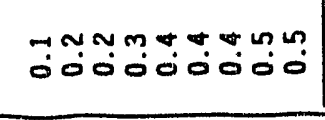 \\
\hline \multirow{5}{*}{ 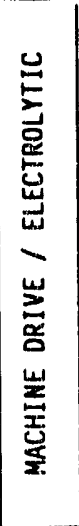 } & 紊 & $\stackrel{m}{m}$ & 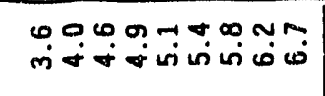 \\
\hline & 岂莡 & $\begin{array}{l}0 \\
\dot{m}\end{array}$ & 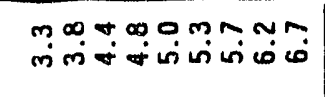 \\
\hline & 要骂 & $\overrightarrow{0}$ & $\begin{array}{l}00000000 \\
\text { 000000000 }\end{array}$ \\
\hline & 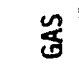 & $\dddot{0}$ & 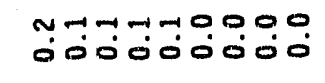 \\
\hline & 呵岂 & $\overrightarrow{0}$ & 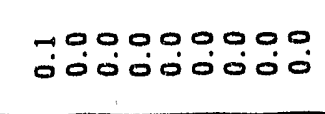 \\
\hline & 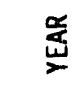 & 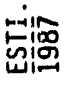 & 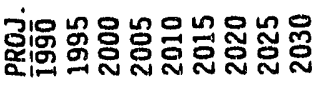 \\
\hline
\end{tabular}




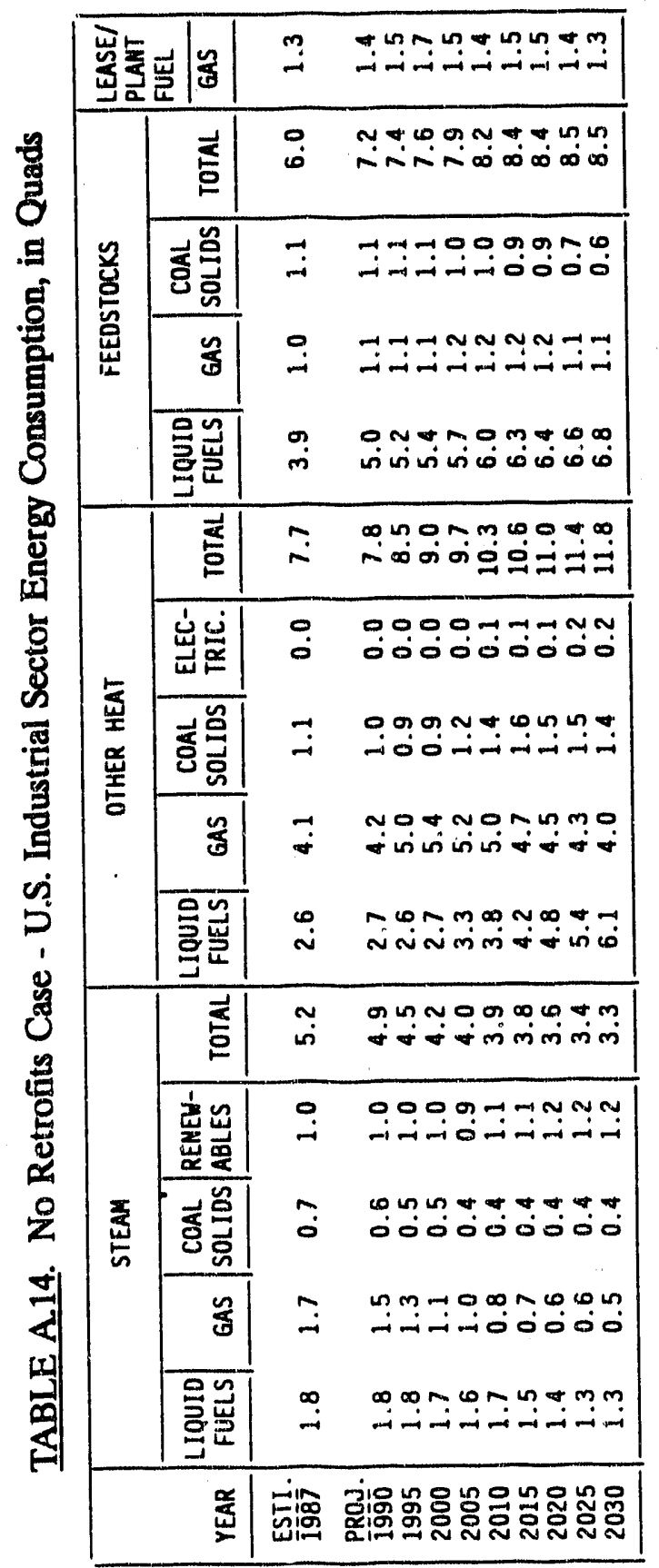

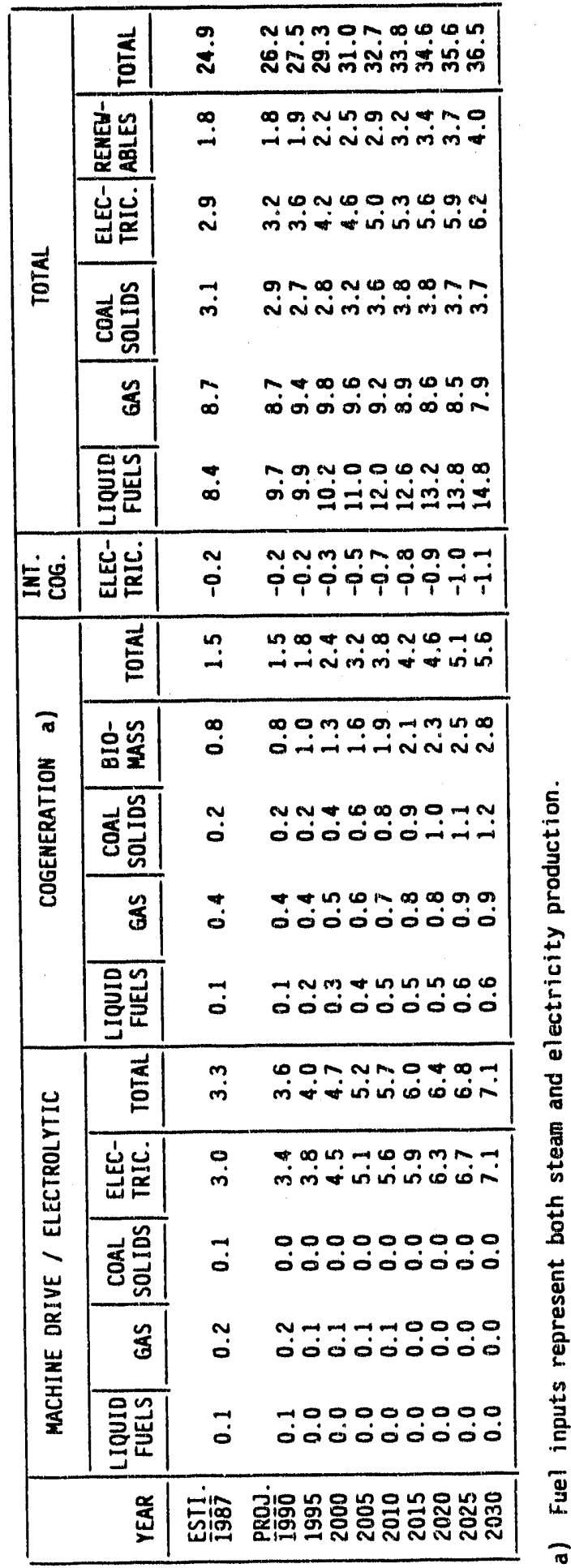




\section{DISTRIBUTION}

No. of

Copies

\section{OFFSITE}

12 DOE Office of Scientific and Technical Information

B. Card, CE-70

U.S. Department of Energy

Forrestal Building

1000 Independence Avenue, S.W.

Washington, D.C. 20585

D. Carter, FE-4

U.S. Department of Energy

Forrestal Building

1000 Independence Avenue, S.W.

Washington, D.C. 20585

J. Conti, EI-5

U.S. Department of Energy

Forrestal Building

1000 Independence Avenue, S.W.

Washington, D.C. 20585

J. Dowd, EP-50

U.S. Department of Energy

Forrestal Building

1000 Independence Avenue, S.W.

Washington, D.C. 20585

D. French, EI-632

U.S. Department of Energy

Forrestal Building

1000 Independence Avenue, S.W.

Washington, D.C. 20585
No. of

Copies

K. Friedman, CE-20

U.S. Department of Energy

Forrestal Building

1000 Independence Avenue, S.W.

Washington, D.C. 20585

J. Holte, EI-813

U.S. Department of Energy

Forrestal Building

1000 Independence Avenue, S.W.

Washington, D.C. 20585

J. Pearson, EI-60

U.S. Department of Energy

Forrestal Building

1000 Independence Avenue, S.W.

Washington, D.C. 20585

E. Petersen, CE-70

U.S. Department of Energy.

Forrestal Building

1000 Independence Avenue, S.W.

Washington, D.C. 20585

M. Podolak, EP-64

U.S. Department of Energy

Forrestal Building

1000 Independence Avenue, S.W.

Washington, D.C. 20585

D. Rosenthal, EP-64

U.S. Department of Energy

Forrestal Building

1000 Independence Avenue, S.W.

Washington, D.C. 20585 
No. of

Copies

P. Tseng, EP-64

U.S. Department of Energy

Forrestal Building

1000 Independence Avenue, S.W.

Washington, D.C. 20585

E. C. Watts, EP-63

U.S. Department of Energy

Forrestal Building

1000 Independence Avenue, S.W.

Washington, D.C. 20585

S. Bellanger

Applied Energy Services, Inc.

1001 North 19th Street

Arlington, VA 22209

J. Bluestein

Energy and Environmental Analysis 1655 N. Fort Myer Drive, Suite 600 Arlington, VA 22209

G. A. Boyd

Argonne National Laboratory

Energy and Environmental Division

9700 South Cass Avenue, EES/362

Argonne, II 60439-4815

R. Hwang

MS $90-4000$

Energy Analysis Program

Lawrence Berkeley Laboratory

1 Cyclotron Road

Berkeley, CA 94720

D. Kline

National Renewable Energy Laboratory

1617 Cole Boulevard

Golden, CO 80401
No. of

Copies

P. Lilienthal

National Renewable Energy Laboratory 1617 Cole Boulevard

Golden, CO 80401

M. Ross

Physics Department

University of Michigan

Ann Arbor, MI 48109

W. Short

National Renewable Energy Laboratory 1617 Cole Boulevard

Golden, CO 80401

F. Wood

Applied Energy Services, Inc.

1001 North 19th Street

Arlington, VA 22209

DOE Richland Field Office

D. R. Segna

30 Pacific Northwest Laboratory

W. B. Ashton (2)

P. J. Barton

D. R. Brown

B. R. Kinzey

M. L. Placet

J. M. Roop

R. D. Sands

M. A. Wise (8)

M. G. Woodruff (8)

Publishing Coordination

Technical Report Files (5) 

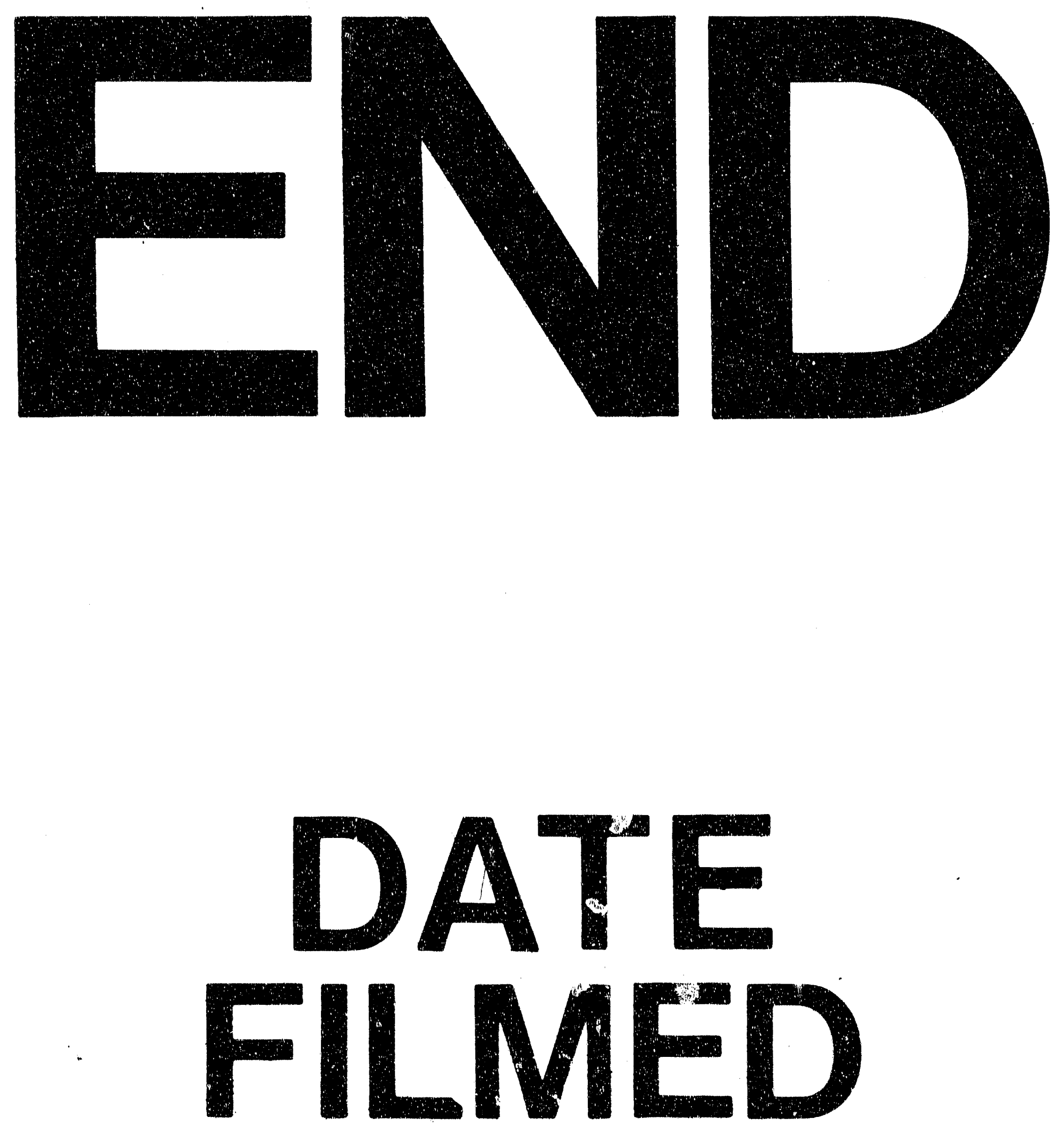

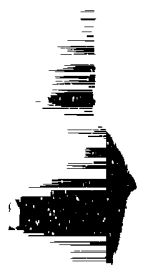

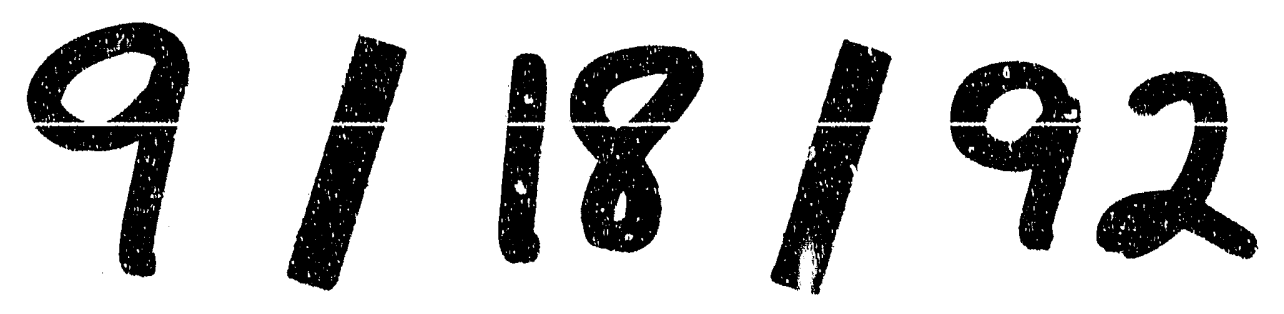


$=$

$=$

$\equiv$ 